Historic, Archive Document

Do not assume content reflects current scientific knowledge, policies, or practices. 



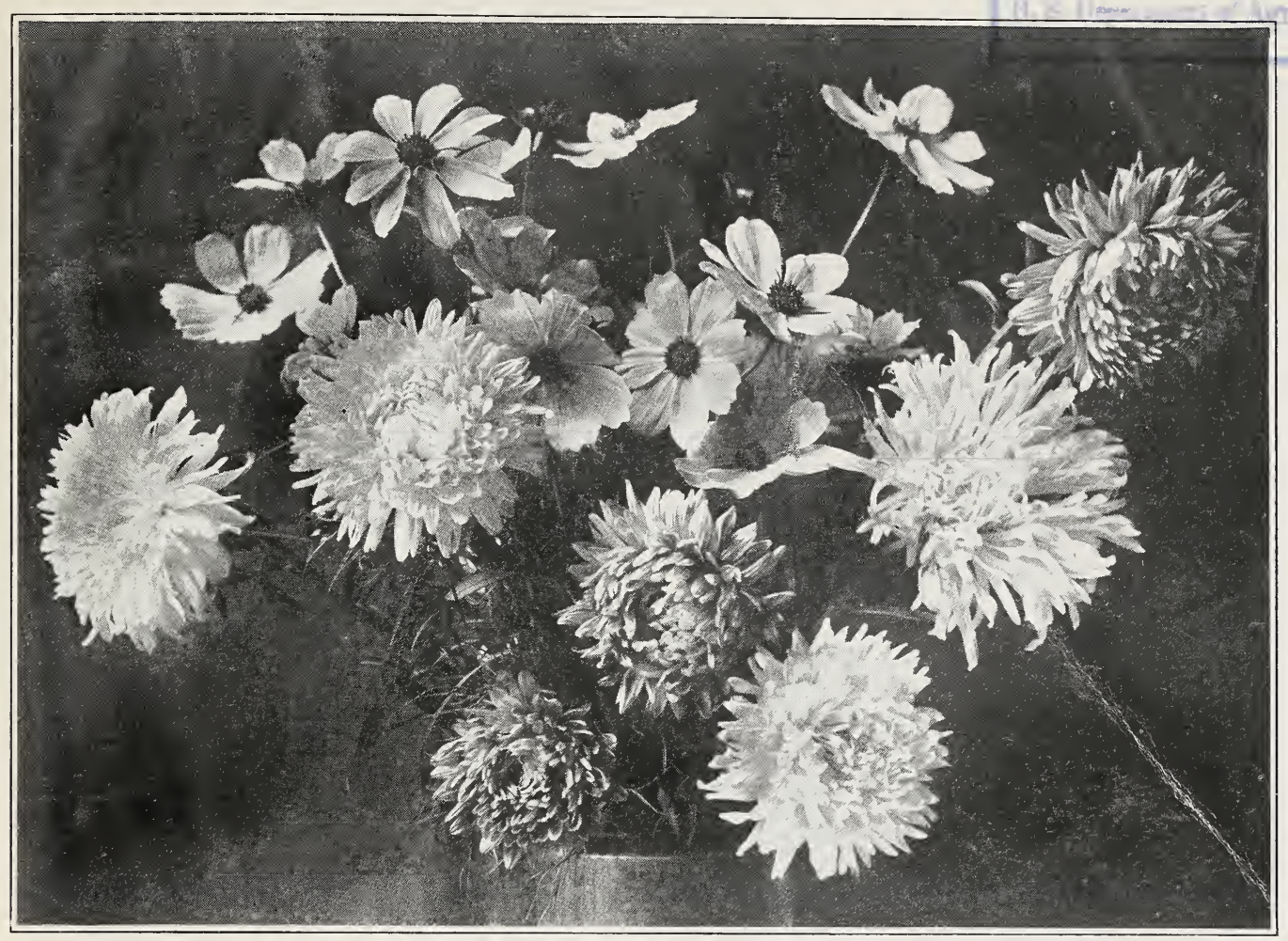

\section{Garden Guide and Catalogue 1925}

\section{QUEEN CITY \\ SEED Eु NURSERY COMPANY, INC.}

\section{NEW LOCATION}

616-618 WASHINGTON STREET

opposite Washington Market BUFFALO, N.Y.

Green House and Nurseries:

SOUTH EGGERTSVILLE ROAD, EGGERTSVILLE, N. Y. 


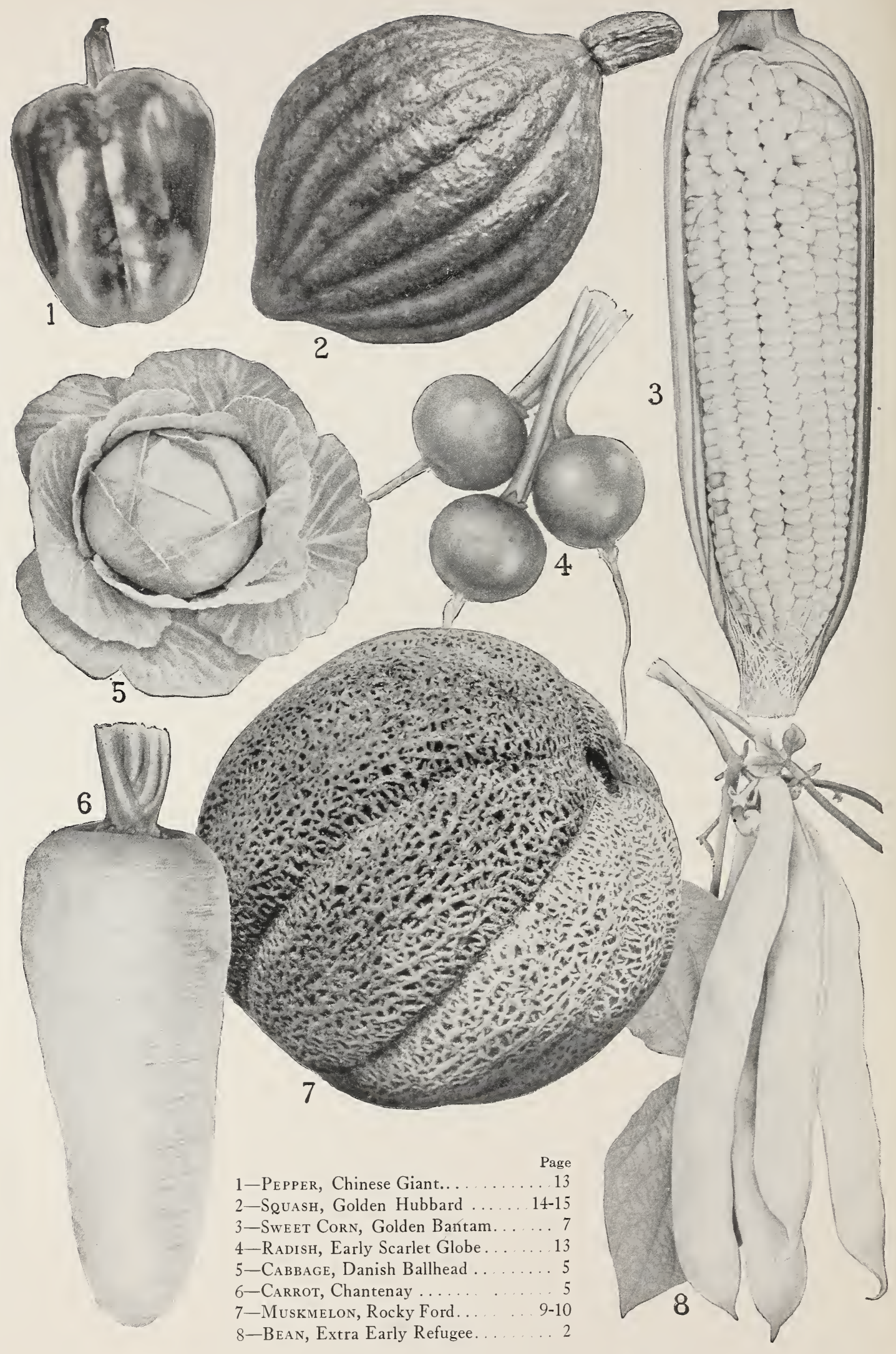




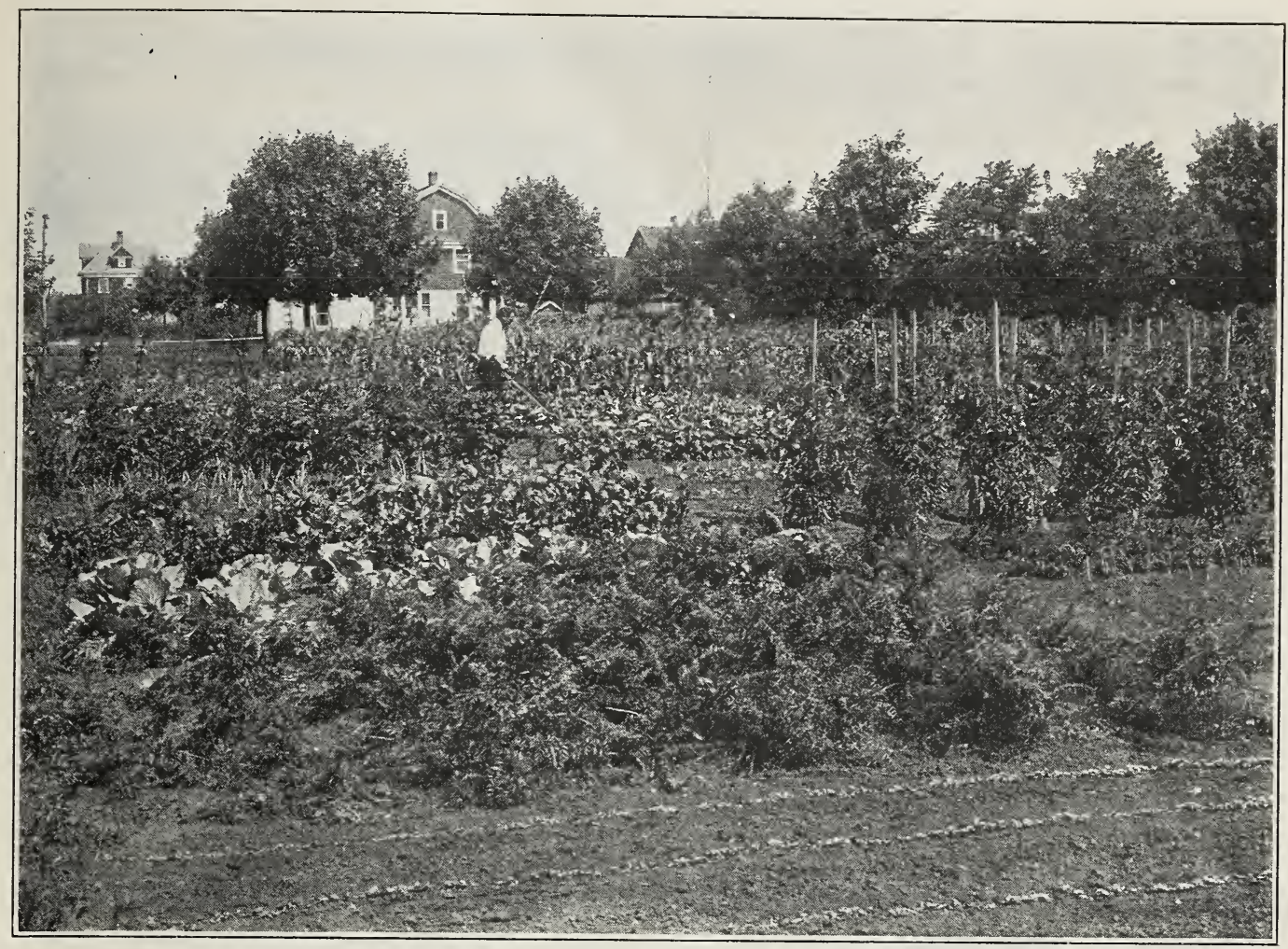

\section{The Home Garden}

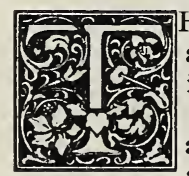

HE "Home Garden" includes the entire grounds or space surrounding your home; the hedge at the front and perhaps also separating you from your neighbors; the foundation planting (shrubs and evergreens) that are placed about your house to finish it, and blend it with its surroundings; the perennial plants; the ornamental trees for shade; the beds of annual flowersfor Summer culture and display; the rose bed, so fragrant and attractive; all are parts of your home garden. No matter how small your house lot,there is always room for your garden. Flowers beautify and are restful. A space devoted to vegetables will repay you many times for the small cost of seeds; crisp radish and lettuce, cucumbers and beans, fresh beets and carrots, luscious tomatoes, sweet, tender corn and other vegetables better than you can buy at the stores can be raised on a small space in sufficient quantities for Summer eating and for canning for Winter.

You will find our present catalogue gives, general directions for the planting and culture of vegetables and flowers, the proper fertilizing and preparing of the garden, a helpful and complete planting table, and a listing of the varieties of Seeds, Perennials, Shrubs and Fruits best suited to this locality.

Seeds of the very best quality sometimes fail through improper treatment. A small seed may be sown too deeply and the young plant cannot reach the surface. More failures result from a disregard of proper conditions than the inferiority of the seeds used. These conditions are: proper temperature, sufficient moisture, free access of air, and proper conditions of the soil.

There is also the well known tendency of some vegetables to revert to former types, yellow podded Wax Beans becoming green; Dwarf Peas becoming running sorts, etc., all of this notwithstanding the care of the seed grower.

Therefore, the Queen City Seed and Nursery Company, Inc., gives no warranty, either expressed or implied, as to description, quality, productiveness, or any other matter of any seeds, bulbs, plants, or shrubs they send out, and they will not be in any way responsible for the crop. If the purchaser does not accept the goods on these terms, they are at once to be returned.

\section{WHEN TO PLANT SEEDS}

Plant the very hardy things, such as Onions, Onion Sets, Smooth Peas, Sweet Peas, Turnips, Radish, Spinach and Early Beets, just as soon as the garden is dry enough to be worked.

Plant the hardy things, such as Cabbage, Lettuce Plants, Cauliflower, Beets, Swiss Chard, Carrots, Wrinkled Peas, Parsnips, Salsify, Potatoes, Kohl-Rabi and Summer Squash when the Pear and Peach trees are in bloom.

Plant the tender things such as Beans, Corn, Cucumbers, Gourds, Melons, Okra, Pumpkins, Squash, when the Apple trees are in bloom.

Plants of Tomatoes, Peppers, Egg Plants, Okra, Melon, Pole Beans, etc., should not be put out until after danger of late frosts has passed. Cover small seeds like Lettuce, Radish, Onions, $1 / 4$ to $1 / 2$ inch deep; medium size, such as Beets, Spinach, Parsnips, $1 / 2$ to 1 inch; and, larger seeds such as Beans, Corn, Pumnkins, 1 to 2 inches. 


\section{Queen City Reliable Vegetable Seeds}

The cultural directions given in this catalogue are for the growing of vegetables in the vicinity of Buffalo. For other localities the climate conditions must be considered. Gardening conditions vary according to latitude and the nearness of large bodies of water which influence temperatures.

The use of hotbeds and coldframes should be more general, even by those having small gardens, Hotbeds are especially valuable for starting early vegetables and many flowers, so they will be ready to set out as soon as the ground is in condition.

\section{ARTICHOKE}

\section{German, Artischoke. Italian, Articrocea.}

One-half ounce enough for 100 feet of row.

Large Green Globe. Perennial, large flowering heads, cooked like Asparagus. Matures second year. Not hardy in the North. Pkt. 10 cents.

\section{ASPARAGUS}

German, Speigel. Italian, Sparagio. One ounce will produce about 200 plants. 4 to 5 pounds per acre.

Culture.-Sow seed thinly in rows 1 foot apart in April or May and keep free from weeds. Thin to

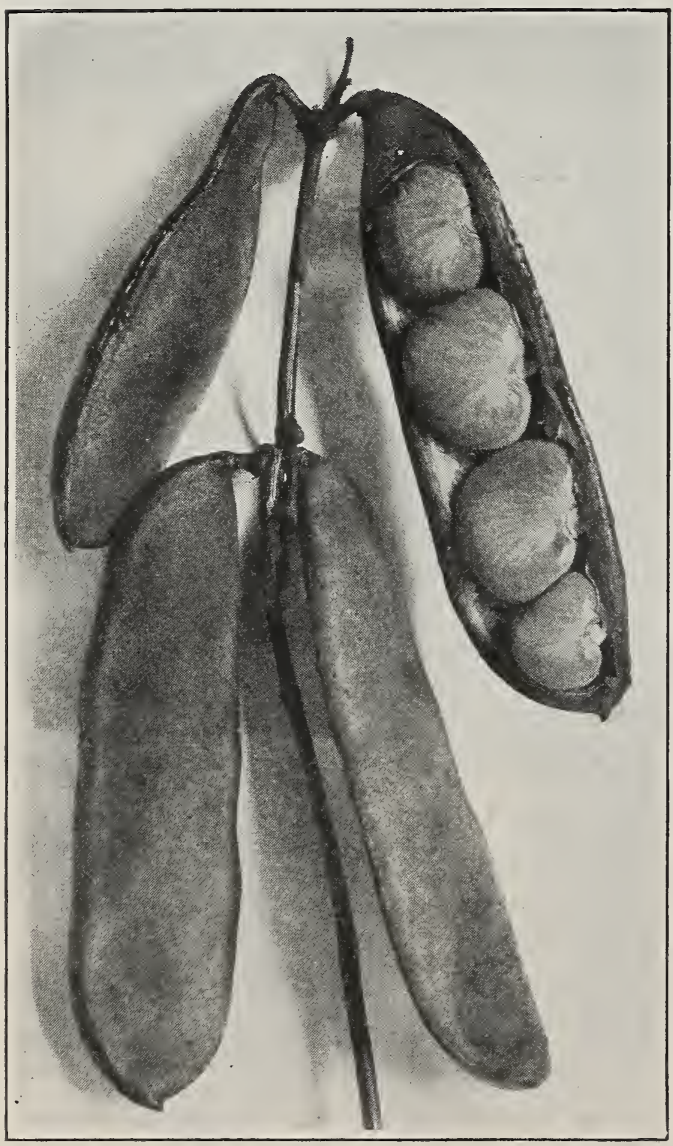

Henderson's Bush Lima Beans
3 or 4 inches apart. Set one-year plants in Spring in good loam dug 18 inches deep and well enriched with well rotted manure. Use sand or sifted ashes if soil is clay. Make bed 5 feet wide, 3 rows in bed, allowing 18 inches between rows. Set plants 2 feet apart, and at least 4 to 6 inches below surface. Cut tops every Fall and burn them, and dress bed with coarse manure. Do not cut closely or roots will die.

Conover's Colossal. A large, green variety, very tender and good. Pkt. 5c., oz., 10c., 1/4 lb. $25 \mathrm{c}$.

Columbian Mammoth White. Produces large, white stalks, very tender. Pkt. 5c., oz. 10c., $1 / 4$ lb. 25c.

Palmetto. An early green variety, prolific and very good quality. Pkt., 5c., oz., 10c., $1 / 4$ lb., $20 \mathrm{c}$.

\section{ASPARAGUS ROOTS}

Colossal. 2-year old. Prices variable.

Palmetto. 2-year-old. Prices variable.

Washington Rustproof. A fine variety of rust resistant and vigorous plants. Prices variable.

\section{BEANS}

German, Bohnen. Italian, Fagiuoti.

One quart to 100 feet of row. 1 to $1 \frac{1}{2}$ bushels per acre in drills.

Culture.-As soon as the ground is warm and danger of frost is past, plant in drills 2 inches deep and 18 inches to 2 feet apart. Drop Beans 3 inches apart and cover not more than 2 inches. Sow every two weeks up to August 1st for succession.

\section{DWARF BUSH, or SNAP GREEN PODDED Pkt., 10c., 1b. 40c., 2 lbs. 70 c.}

Stringless Green Pod, Burpee's. Extra early prolific, pale green, round pods, long and straight, meaty and excellent in flavor.

Refugee, or $\mathbf{1 0 0 0}$ to 1. A late variety with very attractive pods, and round small. One of the best canning sorts.

Extra Early Refugee. A good yielder, pods uniform, round and nearly stringless; a favorite with canners and shippers.

Boston Small Pea. A fine field sort. Good for baking. 


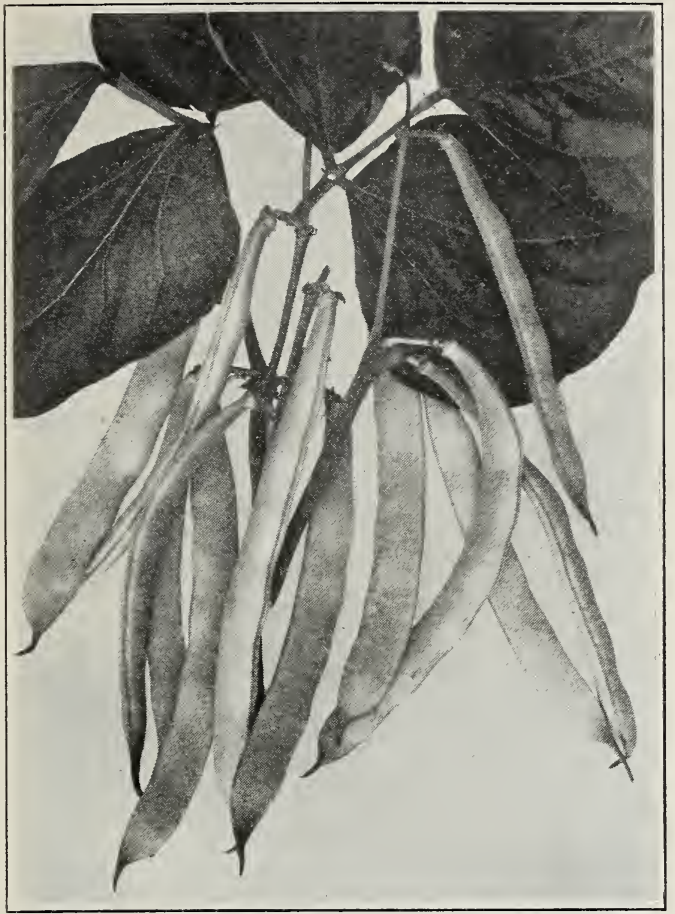

Wardwell's Kidney Wax Beans

DWARF VARIETIES FOR SHELLING

\section{Large White Marrow. Red Kidney.}

\section{DWARF WAX BEANS}

Pkt. 10c., 1b. 40c., 2 lbs. 70c.

Hodson, Wax. A late variety producing large quantities of cream-white pods of fine quality. Flat and brittle.

Wardwell's Kidney Wax. Long flat pods of a delicate waxy yellow, stringless and brittle. Very free from rust and spots.

Davis Kidney Wax. Very reliable and a heavy yielder. Early, vigorous and upright growth. Pods waxy, flat and held well up from the ground.

Pencil Pod Black Wax. Slender, long, round pods. Medium early.

\section{POLE LIMA BEANS}

Two pounds Limas will plant about 100 hills, 4 to 5 Beans to a hill.

Culture.-Sow when soil becomes warm and dry, in hills 4 feet apart each way. Plant 2 inches deep, eye down. Set poles 8 to 10 feet long, in hills, before planting.

Pkt. 10c., 1b. 45c., 2 lbs. 85c.

Large White Lima. An old, standard sort, highly esteemed. Fine for canning.

\section{POLE BEANS}

Pkt. 10c., 1b. 40c., 2 1bs. 70c.

Culture.-Set poles about 4 feet apart each way and plant 4 to 6 Beans, eye down, around each pole. Thin to three plants to each pole. Pinch ends when plants reach top of pole.

One pound will plant 75 to 100 hills.

Kentucky Wonder, or Old Homestead. One of the best green-podded sorts. Pods are 6 to 8 inches long, borne in clusters almost round and curved. Well adapted for home garden. The dry Beans are long, oval and dun colored. An early and very prolific variety.

Scarlet Runner. Plants are of strong, quick growth, bearing large sprays of bright, scarlet, pealike flowers. Pods are green. When ripe the dry Beans are bright scarlet blotched with purple. Used largely as an ornamental vine.

Golden Cluster Wax. Long, thick, broad pods borne in clusters. Extra strong and prolific. Rich golden yellow, stringless and excellent flavor.

\section{DWARF LIMA BEANS}

Two pounds to 100 feet of drill.

Culture.-Plant as soon as warm weather has set in. Soil should be light and rich. Sow in drills 2 feet apart, and 6 inches apart in row, covering about 2 inches, eyes down. Mulching keeps pods from touching the ground.

Pkt. 10c., 1b. 50c., 2 lbs. 90c.

Burpee's Bush Lima. A bush form of the large, flat Lima, 18 to 20 inches high, stout and erect, yet branches vigorously. An immense yielder.

Henderson's Bush Lima, or Dwarf Sieva. This is a small-podded or early variety of Lima. The pods and Beans are of good flavor, but small.

Fordhook Bush. A most excellent variety and very popular. Pods about 5 inches long, beans oval shaped and thick.

\section{BEETS}

German, Rube. Italian, Barbabietia.

One ounce to 50 feet of drill. 5 to 6 pounds per acre.

Culture.-Sow as early in Spring as ground can be worked and every two weeks after for succession, up to first of July. Soil should be light loam well enriched with rotted stable manure or sheep fertilizer, and worked fine. Drills should be 12 to 14 inches apart and seed covered lightly. Thin plants to 4 to 6 inches apart. The young plants make excellent greens.

Crosby's Egyptian. Used by market gardeners for forcing and early out of door planting. This Beet is flattened globe shape very dark red, equally good for early bunching as well as for Fall market. Pkt. 5c., oz. 15c.

Crimson Globe. A handsome-shaped Beet, little deeper than round, with smooth surface and small tap root. Flesh is deep crimson, ringed and zoned. Good for early bunching as well as for main crop. Pkt. 5c., oz. 15c. 
Eclipse. It is of rapid growth, globe-shaped, and bright crimson color. A very popular sort. Pkt. 5c., oz. 15c.

Detroit Dark Red. A medium early, globeshaped Beet of excellent quality. Has a fine, dark red color which extends throughout the entire Beet and without the lighter rings or zones seen in some other varieties. Smooth and handsome. Pkt. 5c., oz. 15c.

\section{MANGEL WURZELS, or CATTLE BEETS One ounce to 50 feet of drill.}

Used for feeding stock. Sow 6 pounds to the acre in rows 3 feet apart in May or June and thin to 9 inches. Cultivate with horse.

Mammoth Long Red. On good soil, sometimes grows 18 inches long. Skin bright dark red; flesh white with rings of rose-pink. Grood keeper, nutritious and milk producing. Pkt. 5c., oz. 10c.

Golden Tankard. A yellow-fleshed variety highly prized by dairymen for milk producing qualities. Pkt. 5c., oz. 10c.

Giant Half Sugar Feeding. A valuable large yeilding variety for feeding; oval-shaped, skin, rosecolor, flesh white. Pkt. 5c., oz. 10c.

Eiffel Tower. Mammoth size, dark red skin, white and rose flesh.

Klein Wanzleben. White flesh. Wedge shaped, contains much sugar. Pkt. 5c., oz. 10.c

\section{SWISS GHARD, or SPINACH}

\author{
German, Beisskohl. Italian, Bieta. \\ One ounce will sow 100 feet of drill.
}

Culture.-Also called Sea Kale. The midrib is cooked and served like Asparagus. The other portions are used like Spinach. This Beet does not make a large root, but the top makes nice Summer greens. Cut down to the ground, new shoots will spring up and make fast growth. We recommend the Lucullus where the midrib is to be used. Sow seed 1 inch deep.

Giant Lucullus. Pkt. 5c., oz. 15c.

Silver. Produces large, light colored leaves in great abundance and has a mild flavor. Pkt. 5c., oz. 15c.

\section{BRUSSELS SPROUTS}

German, Rosenkohl. Italian, Cavolo di Brusselles. One ounce will sow 200 feet of drill.

Culture.-Highly esteemed for boiling in Fall and Winter. Resemble miniature Cabbages, growing closely on the stalk from tip to ground level. Quality and flavor is improved by frost. As sprouts begin to grow big, break off the big leaves near them. Sow thinly, early, as soon as ground is fit, in seed bed in rows 1 foot apart and cover $1 / 2$ inch deep. Thin to 2 inches apart and transplant in June to at least 1 foot apart and rows $1 \frac{1}{2}$ foot apart. Rich loam is best.

Long Island Improved. This is the finest strain of Sprouts grown. Pkt. 5c., oz. 25c.

Dalkeith. Plants grow about 20 inches tall, sprouts 2 inches in diameter, hardy and fairly early. Pkt. 5c., oz. 25c.

\section{BORECOLE, or KALE}

German, Blatterkohl. Italian, Carvolo Verde One ounce to 300 feet of row. 4 pounds to an acre.

A popular, boiling green for Fall, Winter and early Spring use. Hardy in well drained soil and can be easily grown from seed sown during the Summer months; plants are usually cut off when leaves are 6 inches or more, but with the fine curled varieties the leaves can be gathered when of good size. With the tall Scotch, the lower leaves are pulled off and plant allowed to grow a further supply. Improved by freezing weather. Protect by mulch during Winter. Cultivation same as Cabbage.

Dwarf Curled Scotch. Very finely curled, dwarf, spreading variety, very hardy. Pkt. 5c., oz. 20 c.

Tall Curled Scotch. Two to three feet high. Long plume-like, green leaves. very hardy. Pkt. 5c., oz. $20 \mathrm{c}$.

Siberian Dwarf. Extremely hardy, broad leaves. Pkt. 5c., oz. 15c.

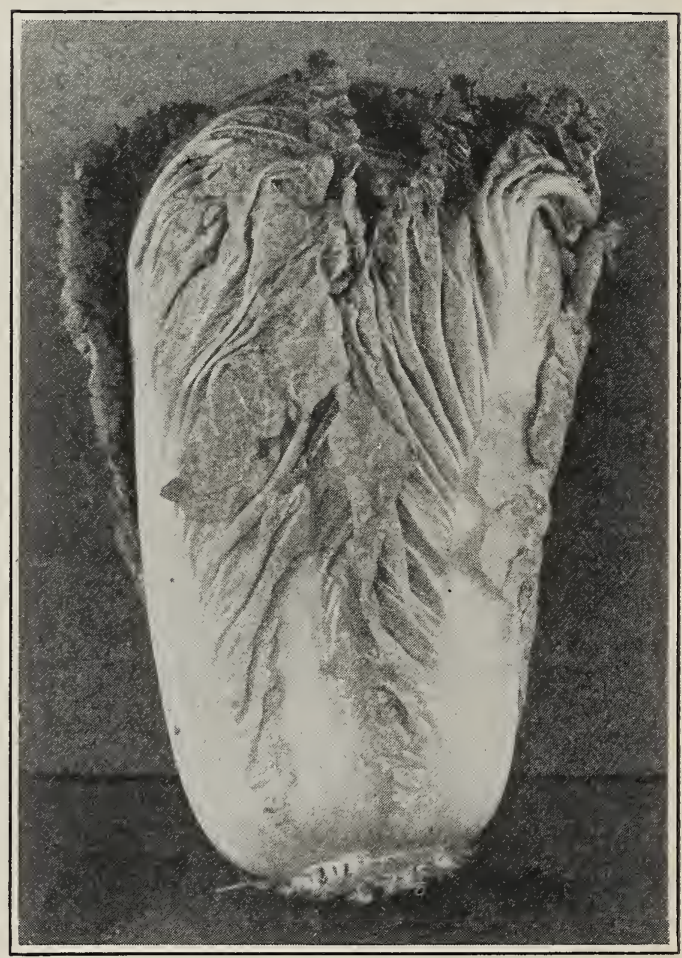

CHINESE, or CELERY CABBAGE

Called Pe-Tsai by the Chinese, who are the originators of this wonderful cross between a Cabbage and garden Celery. The flavor is delicious whether used raw, cut fine, and eaten as a salad, or cooked as Cabbage. It does not form a head like Cabbage, but when full grown resembles the Cos Lettuce. It is odorless while being cooked and mild in flavor. If you have never planted this vegetable it will pay you to try it this season. Sow seed after July 1st and give plants plenty of room in the rows 3 feet apart. Heads up on approach of cold weather. Pkt. 10c., oz. 30c. 


\section{CABBAGE}

erman,Kopfkohlkraut. Italian, Cavolo Cappuccio. One ounce for 2000 to 2500 plants, 6 ounces per acre.

Culture.-For early varieties sow in February in hotbed or under glass, and prick out into flats or frames 2 inches apart each way. Transplant to open ground as soon as it can be prepared, 20 to 24 inches apart, and rows at least 2 feet apart. Use Vermine for root maggot and Slug Shot for Cabbage worms. A little nitrate of soda around each plant is helpful. For late Cabbage, sow in open ground in May, in drills and transplant in June, and July, giving more room than for early Cabbage. Clean cultivation is necessary to keep down weeds and conserve moisture. Good rich soil is of course necessary for quick growth and large heads. In small gardens sheep manure and Bowker's Vegetable Fertilizer can be used to advantage in the row when planting.

\section{EARLY SORTS}

Copenhagen Market. Very heavy and solid, like the "Ballhead" type, making a large, globeshaped head, but maturing much earlier than the Danish varieties. In fact, as early as Early Jersey Wakefield, and giving a much heavier yield. It is short-stemmed and the leaves closely folded. Pkt. 10c., oz. 35c.

Glory of Enkhuizen. A very fine Cabbage; medium size; makes a ball-shaped head; very firm and of good keeping qualities. About two weeks later than Copenhagen. A good cabbage and also valuable as a second early for market purposes. Pkt. 10c., oz. 35c.

All Head Early. Heads flat, deep and solid; valuable also for late. Seed sown in July and set in August will make fine heads. Largely planted by market gardeners. Pkt. 10c., oz. 25c.

Early Jersey Wakefield. A quick growing early variety grown more largely than any other early variety. Splendid for the market gardener and private use. Medium size, pyramidal in shape with pointed peak. Winters well. Our strain of seed is superior in quality. Pkt. 10c., oz. 25c.

\section{SECOND EARLY OR MAIN GROP}

Winnigstadt. An old and famous type of early and second early Cabbage. Makes a large, conical head, color bright glossy green. A vigorous grower, thriving under favorable conditions. Pkt. 10c., oz. 30c.

Early Flat Dutch. Heads are flat and solid, stem is short. Very close heading and quality excellent. Pkt. 10c., oz. 25c.

\section{LATE VARIETIES}

Danish Ballhead. Remarkable for the solidity of its heads and its long keeping qualities. Exceedingly fine grained, tender, crisp, solid and no waste. Few outer leaves. Commands a higher price in the market than any other variety. Seed imported direct from Denmark. Pkt. 10c., oz. 35c.

Danish Short Stem. Ready for market about 10 days earlier than Ballhead. Heads medium size, light in color. Outer leaves set very close, producing more weight per acre. Seed imported direct from Denmark. Pkt. 10c., oz. 35c.
Selected Late Flat Dutch. Remarkably hardy, a sure header, uniform in shape, size and color. Large size. Grown very extensively for a late crop. Pkt. 10c., oz. 25c.

Large Late Drumhead. Heads large, flat and solid and a good keeper. Pkt. 10c., oz. 25c.

\section{RED CABBAGE}

Mammoth Red Rock. The best, largest and hardest heading red Cabbage in cultivation. Heads are round, of deep red color, and weigh 10 to $12 \mathrm{lbs}$. Rapid grower. Pkt. 10c., oz. 35c.

\section{SAVOY CABBAGE}

Drumhead Savoy. The best of its class for home use and market. Solid headed and has the rich flavor of Cauliflower. Heads large, solid and compact. Pkt. 10c., oz. 30c.

\section{CABBAGE PLANTS}

As we grow our Cabbage plants at our own greenhouses at Eggertsville, we can furnish early plants in many varieties in flats, thoroughly hardened off and ready for planting out. Also late varieties grown in coldframes, bunched, in 100 and 1000 lots. Prices upon application.

\section{GARROT}

German, Carotten Mohren. Italian, Carota. One ounce will sow 100 feet of drill. 3 to 4 pounds per acre.

Culture.-Carrots do best in rather light and fairly fertile soil, deeply plowed and warm. For early crop sow seed of the early, short-rooted varieties early, in drills 15 inches apart, covering $1 / 2$ inch deep. Press soil firmly as the seed is slow to germinate. Thin to 3 or 4 inches apart. If plants are too close together a small, inferior crip will result. Sow later, in June or even in July, for main crop, using the longer varieties.

Chantenay. Deep red flesh, fine grained and sugary. Early, grows about 6 inches long; stump rooted and smooth. One of the best for home use, or market garden. Pkt. 5c., oz. 15c.

Oxheart, or Guerande. Intermediate between the half long varieties. About 4 to 5 inches long and very thick. Flesh is orange color and sweet. Will grow on soils too stiff for the longer varieties. While most valuable for stock feeding, it is also good for table purposes while young. Pkt. 5c., oz. 15c.

Early Scarlet Short Horn. May be planted very early and is an excellent Summer variety. This variety is best when young and should be used before it has made full growth. Is short and nearly round, and good for shallow soil. Fine for forcing and early home use. Flesh is deep orange-color and excellent flavor. Pkt. 5c., 0z. 15c.

Danvers Half-Long. Grown more extensively than any other variety. Color is a rich orangered, smooth and handsome. Roots taper to a blunt point; flesh sweet, crisp and tender. Fine for the amateur gardener as well as the market grower. Pkt. 5c., oz. 15c. 


\section{CARROTS FOR STOCK FEEDING}

Sow 4 pounds to the acre.

Large White Belgian. The roots grow partly above ground and are thick, yielding a heavy crop. Harvest before frost. Used only for stock feeding. Pkt. 5c., oz. 15c.

Large Yellow Belgian. Same as White Belgian, except that the flesh is yellow. Used for stock feeding only, as the flesh is rather coarse. Pkt. 5c., oz. 15c.

\section{GAULIFLOWER}

German, Blumenkohl. Italian, Covodoflore. One ounce of seed will produce about 3000 plants.

Culture.-For earliest Cauliflower, sow seed in hotbed or greenhouse during February or early March, and transplant to flats or coldframes 2 or 3 inches apart each way. Set in open ground in the Spring as soon as it is in condition. Soil should be warm, rich and well supplied with humus and moisture. Light dressings of nitrate of soda is of much help. Set plants 2 to $21 / 2$ feet apart each way. When heads are formed and hard, blanch by drawing the leaves together and tying with raffia or strips of soft cloth. For late Cauliflower for pickling, start plants in open ground like late Cabbage, and handle like that crop.

Early Snowball. For main crop and for every purpose, except for first early or for culture under glass, we recommend this variety as being of the highest quality and a reliable, sure cropping strain. Pkt. 20c., oz. \$1.50.

Extra Early Paris. An old variety and still much used by gardeners. Pkt. 20c., oz. 75c.

Veitch's Autumn Giant. A large, late variety, producing large, compact white heads. In this locality the earliest varieties are the most used. Pkt. 20c., oz. 50c.

\section{CHIVES}

German, Schnitlauch. Italian, Civaie.

Seed may be sown same as Onion in clumps instead of rows. It is entirely hardy. The green tops which appear in early Spring are used wherever the flavor of Onions is desired. Pkt. 10c., oz. 50c.

\section{CRESS, or PEPPER GRASS}

German, Garten-Kresse. Italian, Agretto.j One ounce will sow 60 to 100 feet of drill.

Culture.-Sow the curled variety in early Spring thickly in shallow drills $1 / 4$ inch deep and a foot apart every two or three weeks until warm weather, in cool, moist garden soil. Sow again in late August for Fall use. Cut often and it will continue to grow. Used as a salad; also for garnishing. Water Cress is sown on the banks of a sunny stream as it delights in cool, moist ground and clear water.

Double Curled. Pkt. 5c., oz. 15c.

Water Cress. Pkt. 10c., oz. 45c

\section{CELERY}

German, Sellerie. Italian, Sedano.

One ounce of Celery seed will produce 3000 to 5000 plants. One package for 100 feet of row.

Culture.-For early Celery sow the self-blanching sorts in flats under glass early in March and transplant into other flats or into coldframes. Set out in May or June in rich soil, 6 inches apart in the rows, and rows 3 to 4 feet apart. Keep free from weeds by thorough cultivation, and blanch when well grown by boards set up against the rows. For late Celery sow seed later in flats or in the open ground. Cover all seed lightly and press soil firmly. Celery seed germinates slowly. Make rows for late Celery, 4 to 5 feet apart. Blanch by earthing up gradually. To store for Winter, dig plants with roots and pack in dark cellar on wet soil.

Golden Self-Blanching. Considered by most growers as the best Celery in cultivation, and most satisfactory for family and market use. Handsome in appearance, the heart being large, solid, golden yellow in color and of delicious flavor. Will turn yellowish white when matured without banking, but is improved by covering the stalks with soil. Pkt. 10c., oz. 60c.

White Plume. The inner leaves and heart of this variety are naturally white, so that blanching is easily completed by drawing the soil around the plant. Crisp, tender and very early and will not keep late. Pkt. 10c., oz. 25c.

Giant Pascal. Solid, thick, cream-colored stalks, handsome in appearance and entirely stringless. A late Celery and keeps in fine condition to January and February. A good shipping variety, free from rust or rot. Pkt. 10c., oz. 25c.

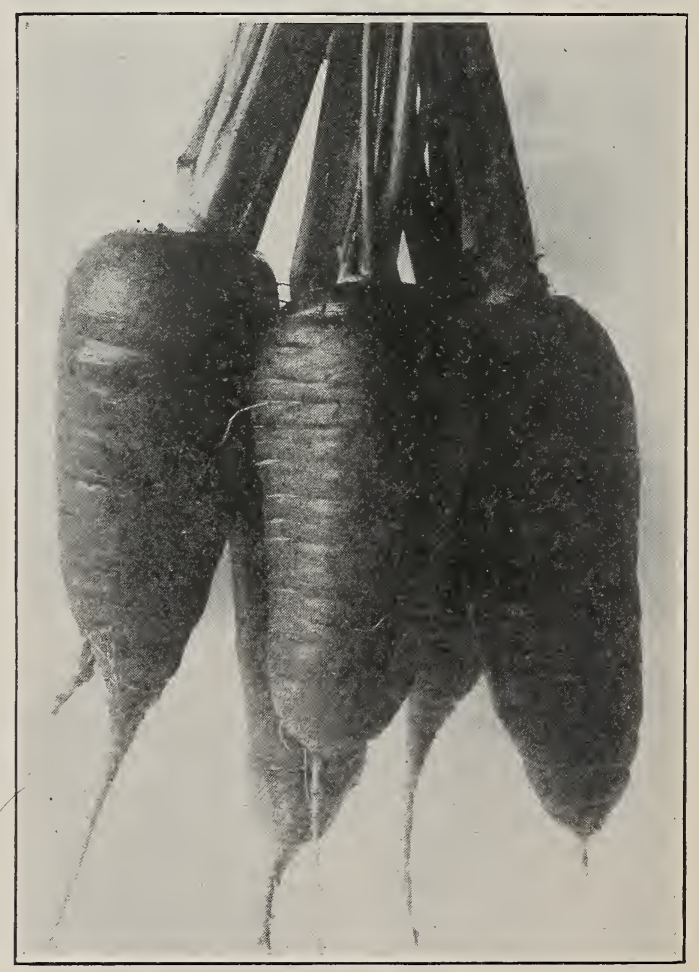

Danvers Half-Long Carrots 
Winter Queen. Grows thick, solid stalks and a large heart. A creamy white when blanched, and quality and flavor is good. An excellent Winter Celery. Pkt. 10c., oz. $25 \mathrm{c}$.

GELERIAC, or TURNIP-ROOTED CELERY German, Knoll-Sellerie. Italian, Sedano rapa. One package is enough for 100 feet of row.

Culture.-Seed is started and plants set in same way as Celery. Grown for its bulbous roots. A very fine vegetable and has a fine flavor when boiled.

Large, Smooth Prague. A very large and smooth-rooted variety. An excellent keeper. Pkt, 5c., oz. 25c.

\section{CUCUMBER}

German, Gurken.

Italian, Cetriolo.

One ounce will sow 60 to 70 hills. Two pounds to the acre.

Culture.-For very early Cucumbers sow seed about April 1st in hotbed, on sods, grass side down so as to transplant readily to open ground when danger of frost is past. For general crop sow in the open ground, when the weather is warm and settled. Sow seed about $3 / 4$ inch deep in hills, 4 to 6 feet apart, and thin to three or four of the strongest plants. Pick as soon as large enough to use. Use well rotted manure in the hills. For pickles sow about July 1st. For wilting and mildew spray well with Bordeaux. For beetles and other insects dust with Slug Shot or use a combined Bordeaux and arsenate of lead spray, such as Pyrox.

Woodruff's Hybrid. Almost as perfect as a hothouse Cucumber. Is 7 to 8 in. long, very smooth and even. Exceedingly productive. Vine is less susceptible to plant diseases. Largely planted by market gardeners. Pkt. 10c., oz. 20c.

Davis Perfect. Fine for forcing or for out of doors. The fruit is long and straight, and fine for slicing as it has few seeds. Pkt. 5c., oz. 15c.

Evergreen White Spine. An extra long, dark green Cucumber. Fine for slicing and an excellent variety for shipping. Pkt. 5c., oz. 15c.

Improved Long Green. Long and crisp; a popular variety for pickling. Pkt. 5c., oz. 15c.

Ghicago Pickling. Known the country over as a very valuable pickling variety. Fruit is fine, dark green color and tapers at both ends. Pkt. 5c., oz. 15c

Early Frame, or Short Green. Very productive. Good for pickling. Pkt. 5c., oz. $15 \mathrm{c}$.

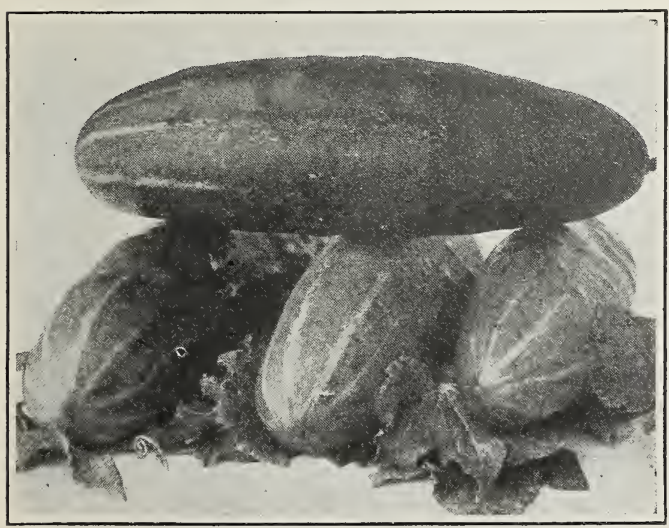

Woodruff's Hybrid Cucumber
Gherkin. West India, grown for small pickles. fruit small. Pkt. 5c., oz. 20c.

Japanese Climbing. Can be trained on fences or trellises. Produces good fruit for slicing or pickling. Pkt. 5c., oz. 20c.

Klondike. Medium early, uniform thick short and blocby Dark green and holds well. Pkt. 5c;

Telegraph for Forcing. Suitable only for growing in frames or greenhouses. Also called Duke of Edinburgh. Pkt.20c.

\section{CORN, Sweet, or Sugar}

German, Mais.

Italian, Mais.

One pound will sow 100 hills or 150 to 200 feet of row. One peck to an acre in hills.

Culture.-The seed of Sweet Corn is liable to rot if planted while ground is cold and wet. Plant in hills 3 feet apart, covering $1 / 2$ inch deep and thin out to three plants to a hill, or plant in rows 4 feet apart, 12 inches apart in row. For succession sow every two weeks up to July 15 th.

\section{Pkt. 10c., 1b. 35c.}

Golden Bantam. The most deliciously sweet and tender Corn. Small, yellow ears, very early. We place this at the head of our Sweet Corn list, as we consider it the ideal Corn for the home garden. No family garden should be without a plot. of this excellent Corn.

Golden Evergreen or Golden Bantam Giant. Larger than Bantam, ears 8 inches long, 12 to 14 rowed and sweet.

Early Evergreen. This variety is similar to Stowell's Evergreen but it is ready much earlier and remains in good condition for a long time. This is the most popular white Sweet Corn.

Early Mayflower, or Cory's Early. One of the earliest, white, sweet corns.

Black Mexican. This Corn is well remembered by its delicious sweetness and fine qualities. Ears 8 to 10 -rowed, about 8 inches long. Kernels bluishpurple to black. A great home garden favorite.

Country Gentleman. A very popular variety with ears of large size, with deep grains in irregular rows on the cob. Very sweet, milky and tender. A fine late variety. Remains ready for use a long time. Excellent for canning. Pkt. 10c.., lb. $45 \mathrm{c}$.

Stowell's Evergreen. A well-known variety, largely planted for late or main crop, very productive. Ears large and kernels very sugary. Pkt. 10c., lb. $45 \mathrm{c}$.

\section{POP CORN}

White Rice. Makes a large, white, fluffy popped kernel. Pkt. 10c., lb. 35c.

Golden Queen. A splendid variety; kernel when popped is creamy in color and very attractive. Pkt. 10c., lb. 35c.

\section{CORN SALAD}

\section{German, Feldsalat. Italian, Valeriana.}

One ounce will sow about 100 feet of drill.

Culture.-Sow in Spring in drills $1 / 4$ inch deep and 1 foot apart. Thin to 3 inches apart in row. For Winter use sow in August or early September. Soil should be light and warm and previously manured. Just before Winter cover thinly with leaves or straw. Pick leaves when half as large as Lettuce. $15 \mathrm{c}$.

Broad Leaved, or Large Seeded. Pkt. 5c., oz. 


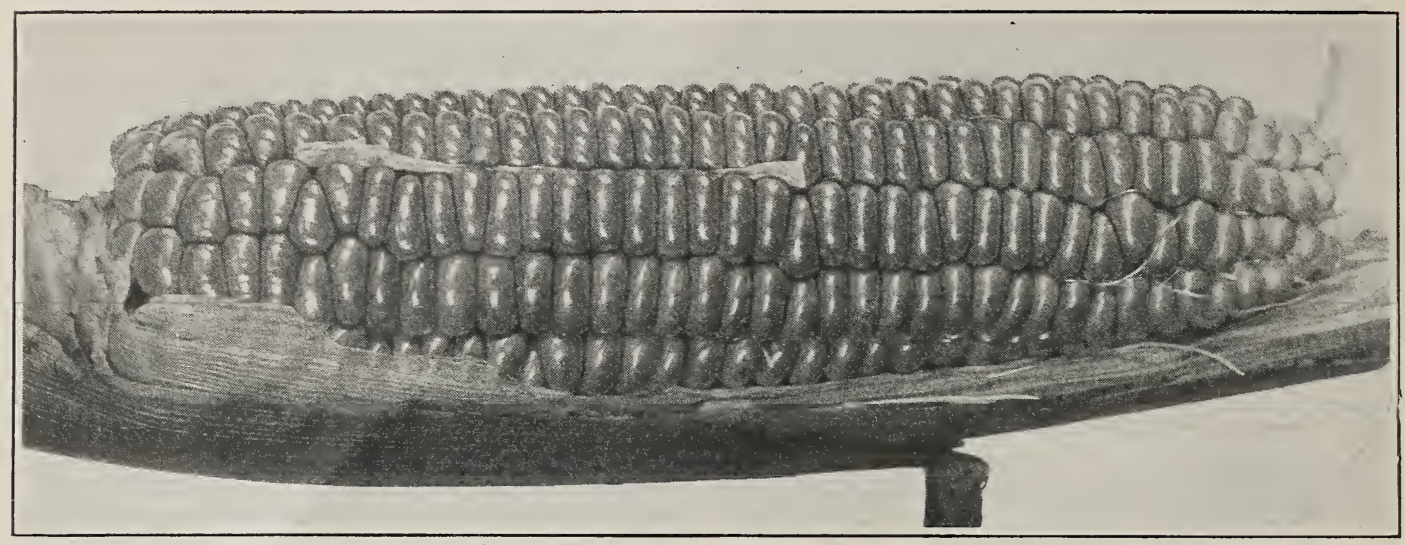

Black Mexican Sweet Corn-See Page 7

\section{EGG PLANT}

German, Eierpflanze. Italian, Petronciano. One ounce will produce about 2000 plants.

Culture.-Sow in hotbeds early in Spring and transplant to pots when 2 inches high, or thin to about 4 inches apart. Do not plant out until weather is warm and settled, as cool nights and wet weather is apt to check growth. Set out plants 2 to 3 feet apart. Fertilize after setting with nitrate of soda or liquid manure.

New York Improved Purple. This variety is a general favorite. Plants are large and spreading, foliage light green; fruits very large, oval and a splendid dark purple. Plants usually have 4 to 8 fruits. Pkt. 10c., oz. 40c.

Black Beauty. As large as New York Improved, but about 10 days earlier. Fruits a dark, rich purplish black. Pkt. 10c., oz. 40c.

\section{ENDIVE}

\section{German, Endiven. Italian, Endiva. One ounce will sow 100 feet of drill.}

Culture. - Sow in June, July or August in good, rich garden soil. Cover lightly. When up, thin to 8 to 10 inches apart and water well if dry. May also be sown under glass in March or April, transplanted and hardened off and then set out as soon as ground is fit. When leaves are 6 to 8 inches long, blanch by tying up with yarn or raffia. (Leaves must be dry or will rot.) At approach of Winter dig with ball of earth attached and pack closely together in frame or cellar. Keep dry and allow plenty of air. Tie tops together to blanch the heart.

Green Moss Curled. Very crisp, tender and of good flavor. It requires protection from cold as it is less hardy. Pkt. 5c., oz. 15c.

Broad Leaved Batavian. Has thick, slightly wrinkled leaves. Usually grown for use in soups and stews. Pkt. 5c., oz. 15c.

HORSE RADISH. See Roots.

\section{KOHL-RABI}

\section{(TURNIP-ROOTED GABBAGE)}

German, Knollkohl. Italian, Cavolo-rapa. One ounce will sow 200 feet of drill.

Culture.-Sow in Spring about 1 inch deep in rows 18 inches apart. Thin plants to 8 to 10 inches apart. If weather is suitable, the thinnings mav be transplanted, but is usually considered difficult to transplant. Do not cover the thick stem or knob. When the thickened stems above ground are 2 to 3 inches through, they are fit to eat and should be used at once, being tough when old. Cook same as Turnips.

Early, White Vienna. Early, small, white bulb. Best for table use. Pkt. 5c., oz. 25c.

Early Purple Vienna. A little later than the white. Bulb is purple. Pkt. 5c., oz. 25c.

\section{LEEK}

German, Porree Lauch. Italian, Porro. One ounce will sow 150 feet of drill.

Culture.-Sow in early April in drills 1 inch deep and 1 foot apart. When plants are 6-8 inches high, transplant to deep rich soil in rows 12 inches apart so that the neck may be blanched. Draw the earth around them as they grow. May also be sown in September and Wintered in frames and young plants transplanted in the Spring.

London Flag. This is the variety usually grown by market gardeners. It is of excellent quality. Pkt. 5c., oz. 20c.

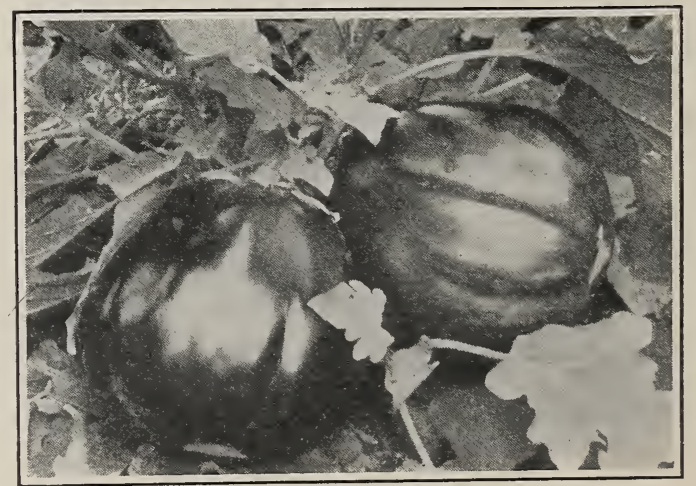

Black Beauty Egg Plant 


\section{LETTUCE}

German, Lattich Kopfsalat. Italian, Lattuga. One ounce will produce about 1000 plants.

Culture.-There are two distinct varieties or classes of Lettuce. One forms a head like Cabbage, the other produces compact heads of loose leaves. The loose-leaved is easiest to grow. All are of good flavor, crisp and tender. Lettuce requires good ground, well fertilized with rotted manure and well pulverized. Lettuce seldom heads well in hot weather. Sow seed in hotbeds or in flats, early. Transplant to flats or coldframes and set out as soon as ground is fit in rows 1 foot apart, allowing 8 to 12 inches apart in rows. For succession sow thinly in open ground and thin or transplant as above.

All varieties. Pkt. 5c., oz. 30c.

\section{CURLED, OR LOOSE HEAD VARIETIES}

Grand Rapids. A splendid forcing variety of upright growth. Produces a mass of beautifully frilled leaves of fine quality in a short time. A good table Lettuce and a good shipper as well. A desirable variety for growing in the home garden.

Black-Seeded Simpson. One of the best known and probably the most largely planted of any Lettuce It is early and hardy and a favorite with market gardeners for planting either out of doors or under glass. Leaves are large, light green, quite crinkled. Compact, but does not form a distinct head. Stands Summer heat better than most varieties.

Prizehead. Well known, loose heading variety, quite distinct on account of the peculiar color of leaves; light green, shading to reddish brown, also crimped at the border. Tender and sweet.

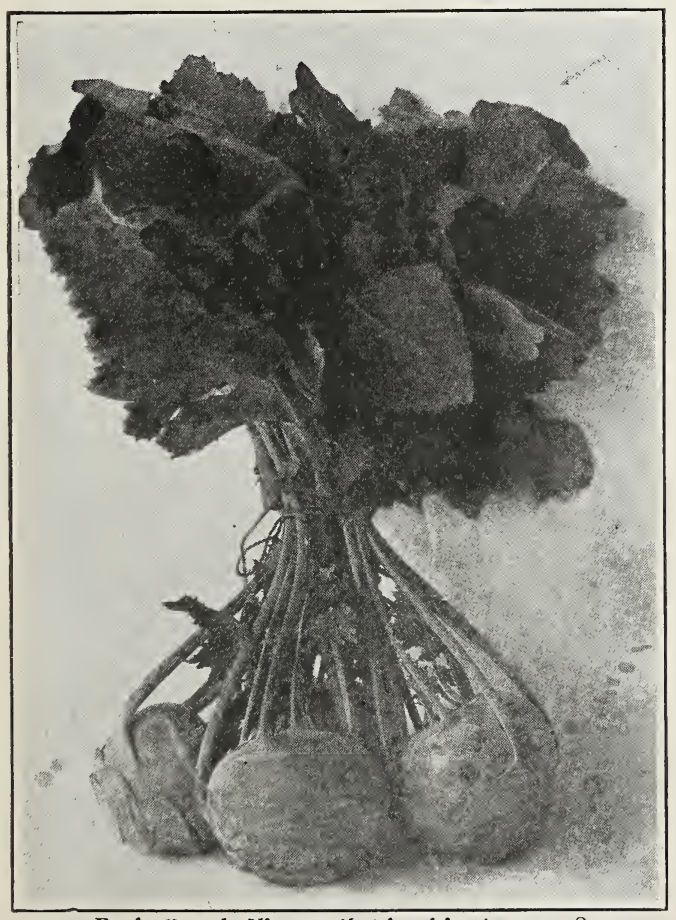

Early Purple Vienna Kohl-rabi-See page 8
Early Curled Simpson (Silesian). Very crisp; strictly a bunching Lettuce. Plant is spreading, covering a rounded, well-blanched, dense cluster of leaves. Color very light green. Very sweet flavor.

\section{GABBAGE, OR HEADING VARIETIES}

Big Boston. A large, heading variety, medium to late. Leaves broad, mostly smooth, some slightly blistered and crumpled, light green with narrow, light brown border. Head broad, slightly pointed and hard. Fine for forcing under glass.

Hanson's Improved. A crisp heading variety, very large and late. Head round, hard and well blanched. Leaves broad, crumpled and twisted. Color very light green.

Iceberg. Crisp, rather than buttery, large and late. Head is round, hard and well blanched. Leaves are slightly blistered, crumpled and twisted. Color, light green, except faint brown borders. Fine quality.

Tennis ball. White Seeded. Excellent forcing sort, medium size head, compact, color green.

May King. Can be planted very early in the Spring. Matures quickly, forming large heads, the inner leaves light yellow and outer ones tinged with brown.

Black Seeded Butter. Heads medium large, firm and oval shaped, color medium green, excellent quality.

Mignonette. Small, early, crisp-curled heading variety, color medium brown, with dark greenish tinge

Trianon Cos, or Romaine. Differs from ordinary Lettuce by the shape of the leaves which are long, spoon-shaped and crisp. Sow seed early in Spring and transplant to about 6 inches apart. When plants are of sufficient size draw leaves together and tie to blanch the inner ones.

Salamander. Heads medium size, very solid, color medium green. Succeeds under most trying conditions. Best all around home garden variety. Identical with Black Seeded Tennisball.

\section{MUSKMELON}

German, Melone.

Italian, Popone. One ounce of seed for 60 hills. 2 to 3"pounds per acre.

Culture.-Prepare hills 4 to 6 feet apart in rich, moderately dry soil, and mix thoroughly with well rotted manure. When ground is warm, plant six to eight seeds, 1 inch deep in each hill. Thin out to three or four plants. Pinch vines when blossoming begins to increase fruitfulness. Cultivate until vines cover ground. Dust with Slug Shot to kill insect pests or spray with Pyrox to prevent blight and insect attacks.

All varieties. Pkt. 5c., oz. 15c. Except as noted.

\section{GREEN FLESHED VARIETIES}

Extra Early Hackensack. An early strain of the well known large Hackensack. Very popular with the market gardeners. Fruit is good size, round and heavily netted. Flesh green, very sweet and good flavor.

Rocky Ford. Vines are productive and Melons mature early, making it very desirable both for home garden and for shipping. Fruit is round and heavily netted. Flesh is thick and seed cavitv is very small. Flavor is delicious, sweet and juicy. 


\section{ORANGE, OR SALMON FLESHED}

Bender. A very delicious large salmon-fleshed melon of superior quality. Oblong but rounded and full on ends.

Osage. Cocoanut-shaped, reddish flesh, light green netted skin. Very sweet and delicious flavor. Well known and in good demand.

Emerald Gem. Medium size and nearly round. Smooth, dark green skin, salmon colored flesh. One of the best for home use.

Irondequoit. Flesh, deep salmon-color and thick, fruit large, round, flattened at ends.

Tip Top Round to slightly oval. Large size. Skin pale, green, flesh deep salmon, sweet and spicy.

\section{WATERMELON}

German, Wasser-Melone. Italian, Melone d'Aqua. One ounce for 30 hills. 4 to 5 pounds per acre.

Culture.-Prepare hills as for Muskmelons, working into the soil plenty of well rotted manure, hen, sheep, or other form, rich in nitrogen. A small amount of chemical fertilizer such as Bowker's will also hasten growth. Plant same as Muskmelons, thinning to three of the strongestplants to a hill. All varieties: $\mathrm{Pkt} .5 \mathrm{c} ., \mathrm{oz} .15 \mathrm{c}$.

Cole's Extra Early. Hardy, medium size nearly round, rind dark green, striped. Flesh deep pink. A most desirable variety for home use or local markets in this locality

Gitron. Used for pickles and preserving.

\section{MUSHROOMS}

Mushrooms are much enjoyed as a table luxury. Beds may be made in a shed, cellar, or under greenhouse benches. Where cellar room is available there is not a better place to grow Mushrooms. The cool, moist temperature is especially suited for their growth.

Complete cultural directions free with each purchase of Spawn, Price per brick, 25c.

\section{MUSTARD FOR SALADS AND GREENS}

German, Semf.

Italian, Senapa.

One package sufficient for $100 \mathrm{ft}$. of row.

Culture.-Sow thickly in shallow drills 12 inches apart early in Spring and press the earth down well. For Fall salad, sow in September, or in frames or boxes during the Winter. Successive plantings may be made every two or three weeks. Do not allow to seed. Used same as Cress, as a salad.

Black or Brown. Leaves oblong, broad and cut. Seeds are the ordinary mustard of commerce. Pkt. 5c., oz. $15 \mathrm{c}$.

Southern Giant Gurled. Leaves much crumpled at the edges and very large. Pkt. 5c., oz. $15 \mathrm{c}$.

\section{OKRA, or GUMBO}

\author{
German, Ocher. \\ Italian, Ocra.
}

Two ounces sufficient for 100 feet of row.

Culture.-Sow late in Spring after the ground has become warm, in drills 3 feet apart, covering 1 inch deep, where the plants are to remain. Thin to 9 to 12 inches apart. The ground should bewell manured. Also may be raised in pots or in hotbed and transplanted. The young seed pods are much used in soups, stews and catsup.

Improved Dwarf. A distinct, early variety with short pods. Pkt. 5c., oz. 15c.

Long Green. An old-time favorite, very productive, with long green pods which are of excellent quality. Pkt. 5c., oz. 15c.

\section{ONION SEED}

\section{German, Zwiebel. Italian, Cipollo.}

One ounce for 100 feet of drill. 4 to 5 pounds per acre.

Culture.-Sow seed as soon as ground can be made ready, about $1 / 2$ inch deep. Thin seeding gives larger Onions than thick seeding. As soon as plants can be seen, cultivate lightly with a rake to pulverize the top soil. Thin to 1 inch apart or 3 inches, if large Onions are wanted. Do not store Onions in large heaps or piles. If they are moist they will heat. Have them perfectly dry and store in shallow crates, well ventilated and in a cool place.

Southport Yellow Globe. Large and fine shaped globe Onions of excellent quality. Well known and regarded by Onion growers as one of the best. Pkt. 5c., oz. $20 \mathrm{c}$.

Yellow Globe Danvers. A well known standard variety for market purposes and for home use. A heavy yielder and good keeper. Skin silvery yellow, flesh white, mild and excellent flavor. Pkt. 5c., oz. $20 \mathrm{c}$.

Southport Red Globe. Fine, globe-shaped, medium size; a good keeper and of superior quality. Pkt. 5c., oz. 20c.

Southport White Globe or White Bunch. One of the most beautiful round Onions. Large size, fine quality and commands a good sale. Market gardeners find it an excellent variety for bunching. Pkt. 5c., oz. 25c.

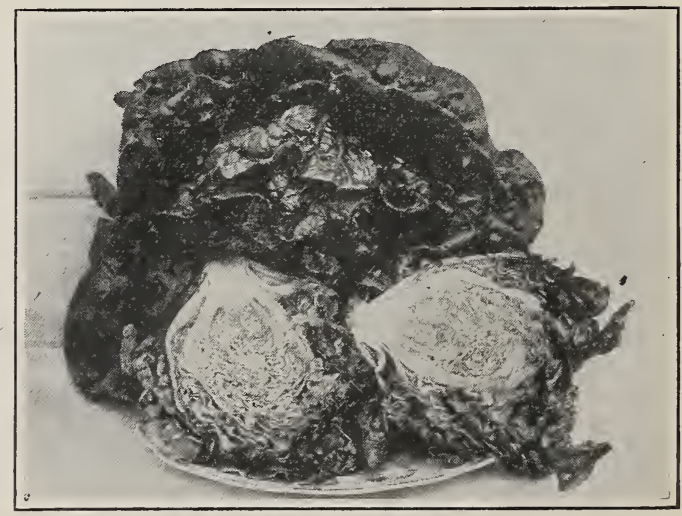

Salamander Lettuce-see page 9 
Ebenezer. One of the best known varieties, especially in the local market. Splendid, globeshaped, good flavor and considered by most market gardners as the best Winter Onion. Large, firm and of good flavor. We offer genuine local grown seed which may be depended upon. Pkt. 10c., oz. $30 \mathrm{c}$.

Prizetaker. The large size and handsome appearance of this variety makes it equally desirable for the market as well as the home garden. It is a "fancy" Onion, and is sold on the market as a Spanish Onion. The true Prizetaker is round, has pale yellow skin and white flesh which is mild and of delicate flavor. Pkt. 10c., oz. 30c.

\section{FLAT VARIETIES}

Red Wethersfield. Grows to full size the first season from seed. Large, flat in shape; skin is a purplish-red color and flesh a purplish-white. Rather strong flavored. A fine keeper. Pkt. 5c., oz. 20c.

Yellow Flat Danvers. Same quality as the Yellow Globe Danvers, it being flat instead of round. Considerably grown for sets. It is a heavy yielder and is largely grown for the home garden as well as for the market. Pkt. 5c., oz. 20c.

White Queen. Pure white, small and flat; extra early; fine for pickling. Pkt. 5c., oz. 30c.

Silverskin, or White Portugal. A splendid sort for growing white Onion sets, pickles and for early bunching green Onions. Also make large, white Onions for Fall and Winter use. A medium size flat bulb shape and has a mild flavor. Pkt. 5c., oz. $30 \mathrm{c}$.

White Barletta. A small, white Indian sort, verry early. Good bunching sort. Pkt. 5c., oz. 30c.

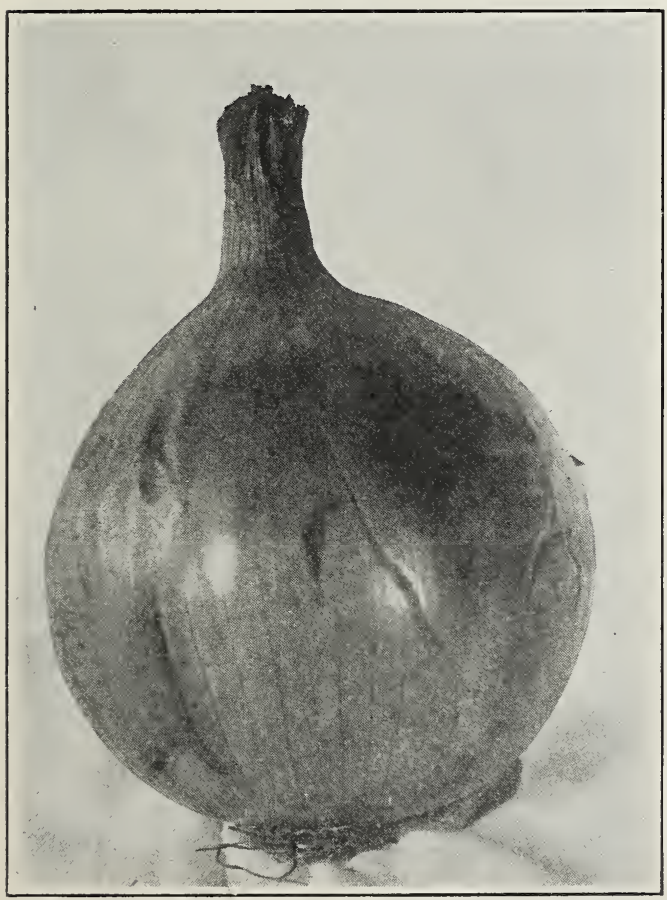

Yellow Globe Danvers Onion-See page 10

\section{GHOICE ONION SETS}

Price variable, subject to market changes. Onion sets should be planted in rows 12 inches apart, 2 inches apart in rows. Good, rich soil and clean cultivation is necessary to obtain good, firm, large size Onions.

White Bottom Sets

Yellow Bottom Sets..............

Ebenezer Sets...................

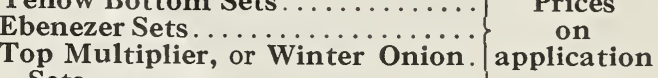

Sets

\section{PEAS}

German, Erbsen. Italian, Pisello.

One quart will sow 100 feet of drill. 60-100 pounds per acre.

Culture-By selecting sorts that do not grow much over 2 feet high the use of brush is avoided. Dwarf sorts are best where space is limited. A selection of varieties and planting frequently for succession will give a supply of choice Peas during the hottest weather. Make furrows 3 to 4 inches deep and 3 feet apart, scatter Peas in them and cover. Cultivate same as Corn and Beans. The late varieties may be planted in double rows with brush for support. Heavy yields cannot be obtained on poor soils. The very dwarf sorts will succeed only on rich soil and may be planted in rows 1 foot apart. All varieties except as noted, pkt. 10c., 1b. 35c.

\section{EARLY VARIETIES DWARF}

Alaska. A well known, early, smooth Pea, extensively used in canning. Vines grow about $2 \mathrm{ft}$. and bear an abundance of pods, dark green in color and of good flavor for so early a variety.

American Wonder. A very fine, extra early variety, well suited for the home garden. Very sweet and productive. Vines not large but bear very heavily. Height, $1 \mathrm{ft}$.

Laxtonian. Large, podded, dwarf variety 18 inches high. Pods and vines dark green. Pods 4 inches long containing 6 to 8 peas.

Nott's Excelsior. An improvement on the American Wonder, being fully as early and pods are larger. Pods are numerous and are well filled with very sweet and finely flavored Peas. Desirable for market and home use. Height, 14 inches.

Premium Gem, or Little Gem. A fine dwarf, wrinkled variety. Vines grow 18 inches high and pods are borne on both sides of stalk and produce large crops. Pods are well filled with finely flavored peas. Desirable for market or home use.

\section{HALF-DWARF WRINKLED PEAS}

Gradus, or Prosperity. A fine, early, largepodded, wrinkled Pea. A favorite in the home garden and for market gardeners. Pods are 4 to $4 \frac{1}{2}$ inches long and the Peas are unusually large, very sweet and of a delicious flavor. 20 to 30 inches.

Thomas Laxton. Resembles Gradus, but is earlier and more hardy. Pods not quite so large, but more productive. For best results give support of some kind. $21 / 2$ to $3 \mathrm{ft}$.

\section{TALL VARIETIES}

Alderman, Wrinkled. A fine second early Pea. It is a vigorous growing, productive variety. Pods are of immense size, dark green in color, and 5 inches in length. Peas are large and sweet and tender. 
Tall Telephone, Wrinkled. An old well-known variety. One of the best late maturing varieties. Pods are large, containing 8 to 10 Peas of good flavor and quality. 4 feet.

Mammoth Melting Sugar (Edible Pod). Large broad pods, brittle and stringless. Very sweet and tender.

\section{SEED POTATOES}

\section{(SELECTED.)}

Northern grown stock selected and especially grown for seed purposes.

One peck will plant about 100 feet of row or 100 hills.

Culture.-For early Potatoes which mature in 8 to 10 weeks from planting the soil must be rich. Cut the tubers so that there will be 2 to 3 eyes to each piece. Plant in hills or rows 3 feet apart, and from 15 to 18 inches apart in the row. Spray the leaves of the young plants with Bordeaux and Arsenate of Lead, or Pyrox, as a protection against blight and Potato beetles. The longer the tops can be kept green the greater the yield, so spray several times to prevent late blight.

Early Ohio. This variety is fully two weeks ahead of the Early Rose and is a general favorite. One of the most profitable Potatoes to grow. Vines are erect and easy to cultivate. Tubers are compact in hill, making them easy to dig and very few small ones. Cooks dry and mealy. Produces a very large and profitable crop.

Irish Cobbler. One of the first varieties to be ready for the market, therefore commands a good price. Skin is creamy white, sometimes netted, which indicates food quality. Flesh is white and of fine flavor.

Early Rose. One of the older popular varieties. It is productive and of excellent table quality. Early and does well even on poor land.

Rural New Yorker. A most popular main crop variety. Does best as a rule on dry soil and black soils. Easily grown, a good keeper and always yields well.

Carman No. 3. A grand main crop variety. A very heavy yielder and very few small tubers. Is of large size and fine shape; keeps well. Skin and flesh is very white, eyes few and shallow; late in ripening.

Certified No. 9. A Potato of great merit. A splendid main crop variety and a big yielder. Tubers are very large and smooth and good shape. Flesh is white and firm and mealy when cooked. No false hearts. Vines very resistant to blight. The seed we offer is extra selected and is the result of several years' inspection and selection. A splendid Potato for baking.

Prices are variable and subject to market changes. Shipped by freight or express as directed by purchaser, who assumes all risks.

\section{PUMPKIN}

\section{German, Melonen-Kurbiss. Italian, Zucca. One ounce will plant 30 to 50 hills.}

Culture.-Seed may be planted with Corn, but prove more profitable when planted in fields by themselves. Sow as soon as ground is warm in hills 8 feet apart. For exhibition Pumpkins, sow Mammoth Tours and feed liberally with liquid manure.

All varieties: $\mathrm{Pkt} .5 \mathrm{c} ., 0 \mathrm{0} .15 \mathrm{c}$.
Winter Luxury. A fine cooking sort, 10 to 12 inches in diameter. Golden yellow, netted somewhat like a Muskmelon. One of the best to store for Winter use.

Mammoth Tours, or Pot Iron. Grown chiefly for exhibition purposes and for stock feeding. Enormous size, sometimes weighing over $100 \mathrm{lbs}$. Skin salmon color, flesh yellow. Keeps long time.

Small Sugar. One of the best for the home garden. Excellent for pies, nearly round, rich orange color, fine grained and very sweet. 10 to 12 inches in diameter.

Connecticut Field. Grown largely for stock feeding but is also suitable for table use. An excellent keeper.

\section{PARSLEY}

German, Petersilie. Italian, Prezzemolo.

One ounce for 150 feet of drill.

Cuture.-Succeeds best in a mellow, rich soil. Sow early in rows 1 foot apart and $1 / 2$ inch deep. Thin to 6 inches apart in rows. Seed is slow to germinate. Soak seed for a few hours in warm water to assist germination. Used for garnishing and seasoning soups, meat, etc.

Champion Moss Curled. Extra large, dark green, tender, crimpled and curled. Especially recommended for either greenhouse or outdoor planting. Pkt. 5c., oz. 15c.

Plain, or Single. Plain leaves of excellent flavor. Last longer than those of the curled varieties. Pkt. 5c., oz. 15c.

Hamburg, or Turnip Rooted. The fleshy root is the edible portion. Highly esteemed for flavoring soups, stew, etc. Pkt. 5c., oz. 15c.

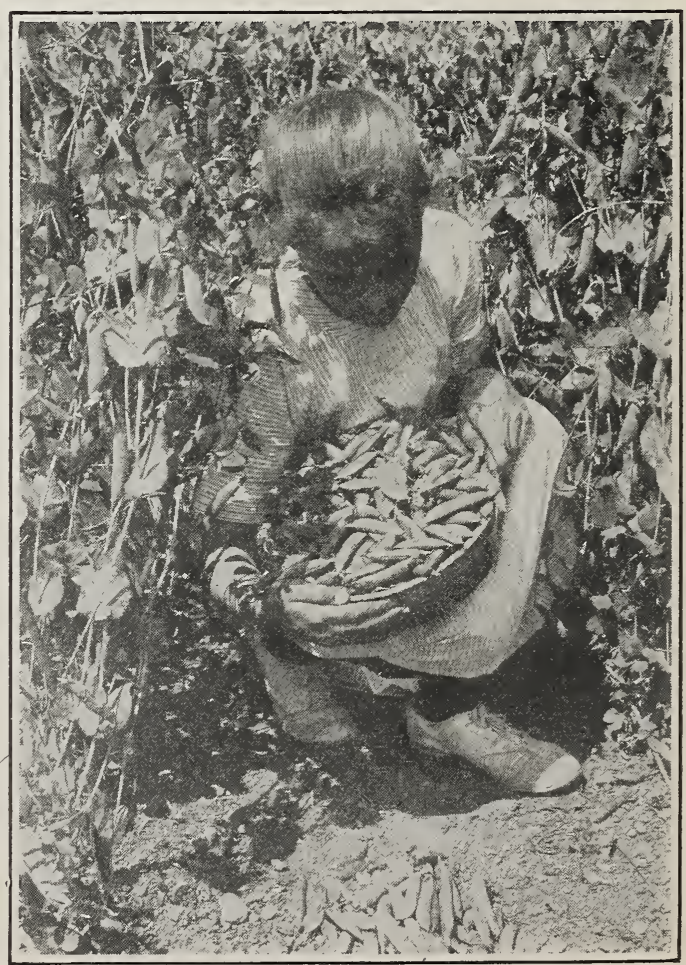

Telephone Peas 


\section{PARSNIP}

German, Pastinake.

Italian, Pastinaca.

One ounce for 200 feet of drill. 5 to 6 pounds per acre.

Culture.-Sow as early in the Spring as the ground can be made fit, in drills 18 inches apart and 11/2 inches deep in rich, deep soil. Thin to 3 to 6 inches apart in rows. The flavor is improved by leaving in the ground over Winter or may be dug late in the Fall, piled loosely and covered with leaves or Cornstalks until frozen and then placed in cellar or pits for use during the Winter.

Large Sugar, or Hollow Crown. The best variety. Roots long, smooth, white, tender and sugary. Very uniform in size and especially fine both for market, as well as for home use. Pkt. 5c., oz. 15c.

\section{PEPPER}

German, Pfeffer. Italian, Peperone.

One ounce of seed for about 1000 plants.

Culture.-Peppers are more tender than most vegetable plants. Seed should be sown in hotbed or coldframe. A box in a window will answer if no other place is available. Sow early in March, and transplant to flats when 2 inches high. Set in open ground when weather is warm and settled, in rows 2 feet apart, with plants 12 to 15 inches apart in rows. Good, rich soil is necessary for good growth. Pkt. 10c., oz. 40c.

\section{SWEET VARIETIES}

Chinese Giant. One of the best large, sweet Peppers. Fruits are bright scarlet, with thick flesh, very sweet and only a trace of fieriness. Requires a long season.

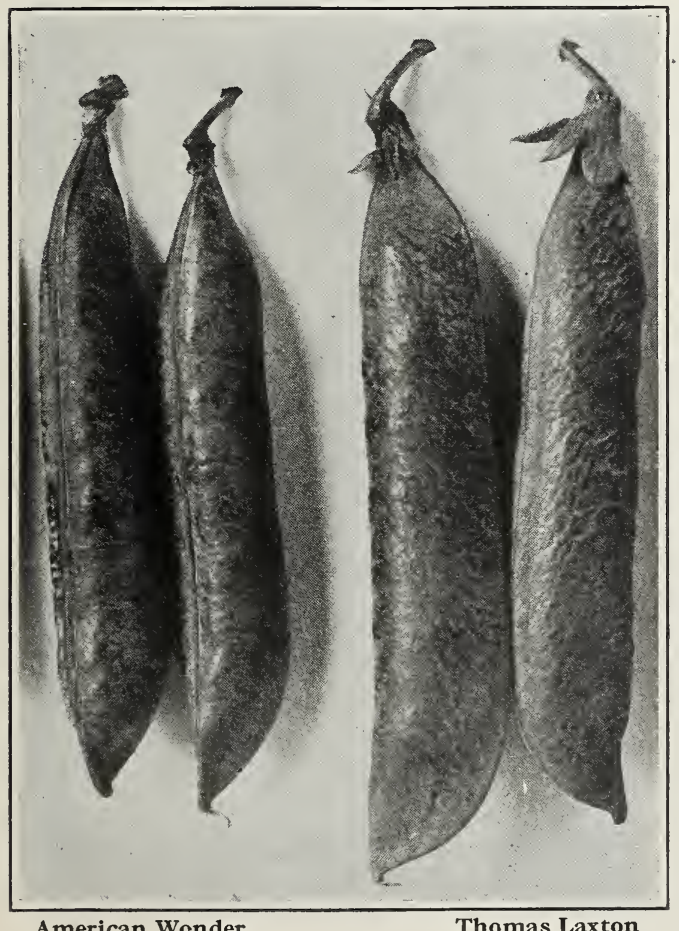

American Wonder

Thomas Laxton
Pimento. The sweetest Pepper grown. Fruit is of medium size and very desirable for filling. Used also for flavoring salads. Flesh is quite thick and skin may be removed by scalding. When ripe the Peppers are a brilliant red and very attractive.

Large Bell, or Bull Nose. A standard variety of vigorous growth. Fruit is of good size, dark green, turning to red at maturity. Mild, pleasant flavor.

Sweet Mountain. Very similar to Large Bell. Very popular stuffed and for pickles.

Ruby King. Bright red, 4 to 6 inches long, mild One of the best sorts for stuffing.

\section{HOT VARIETIES}

Long Red Cayenne. Pods long and slender; green, turning to bright red and very pungent. Used also extensively for bunching with pot herbs.

Red Chile. Very productive. Small, red and very pungent.

\section{RADISH}

German, Radies Italian, Ravanelo One ounce to 100 feet of drill. 8 to 10 pounds per acre.

Culture.-Sow early in good, warm, fibrous loam. If sandy, Radishes will mature a crop in four to six weeks from planting. Use fertilizers freely. Have rows 1 foot apart and sow thinly so that they will not require thinning. The short or Turnip-rooted are easiest and quickest to grow, also good for forcing. For succession, plant any time when you have a small spot in your garden available.

\section{All varieties. Pkt. 5c., oz. 15c. \\ GLOBE AND TURNIP-ROOTED VARIETIES}

Early Scarlet Globe. A round, red, Globeshaped Radish with small top and very quick growth. A standard variety for early outdoor planting for the home garden and market.

Scarlet Turnip, White Tipped. One of the best early varieties. Roots are nearly round, somewhat flattened on under side. Color is a bright rose-scarlet with a distinct white tip. Flesh is white and of excellent quality.

Early Scarlet Turnip. Small top, quick growth, mild and crisp. Largely used for early planting in the open ground.

Early White Turnip. Very much like the scarlet Turnip but a trifle earlier in maturing. Skin and flesh is pure white.

French Breakfast. An oblong-shaped variety. Color is a beautiful scarlet with a clear white tip. Fine for open ground or for forcing. Of excellent quality.

\section{HALF-LONG AND LONG VARIETIES}

Long Scarlet Short Top. A well known variety and extensively planted. Roots 6 inches long, onethird of which is above ground. Color is bright red.

White Icicle. The finest long white Radish. Ready to use in 25 days, but continues to grow and remains in good condition, crisp and tender and mild for a long time. Radishes are a transparent white with small tops.

Strasburg. Roots are about 5 inches long, thick at shoulder and tapering. Flesh and skin pure white. Remains firm and brittle longer than most. varieties

Stuttgart. Large, top-shaped, about four inches in diameter. Clear white. Fine summer or fall radish. 


\section{WINTER VARIETIES}

Culture. - Sow seed at the same time as you would sow Winter Turnip, so they will be crisp and tender. The proper time is late in Summer. They grow to large size, have hard, firm flesh, and can be kept in good condition all Winter by packing in moist sand or soil and removing to your cellar before ground freezes in the Fall.

Chinese White. A large, smooth, white Radish, round in shape and 6 to 8 inches long. Mildest flavored of the Winter sorts.

Chinese Rose. Not quite so large as the white variety and more pungent. Skin bright rose, flesh white.

Long Black Spanish. A very long, hardy variety. Skin nearly black and pure white flesh.

Round Black Spanish. A large, Turnip-shaped sort. Skin and flesh same as long variety.

\section{SALSIFY or VEGETABLE OYSTER}

German, Haferwurzel. Italian, Sassefrica.

One ounce for 50 feet of drill.

Culture.-Soil and culture the same as for Parsnips. Sow as early as possible in the Spring. It is hardy and can remain in the ground all Winter for early Spring use, but can be dug in the Fall and treated the same as Parsnips (which see). Used the same as Carrots, or, after being boiled, is made into cakes and fried like oysters. Succeeds best in light enriched, deep soil.

Mammoth Sandwich Island. This variety grows very large and resembles a good size Parsnip. Very mild and delicate in flavor and very popular. Has a nice, oyster-like flavor. Pkt. 5c., oz. 20c.

\section{SPINACH}

German, Spinat. Italian, Spinace. One ounce of seed sufficient for 100 feet drill. 10 to 12 pounds per acre.

Culture.-Sow in early Spring, 1 inch deep in drills 1 foot apart, every two weeks for succession Soil should be rich and light. Spade in plenty of well rotted manure or sheep manure and a good, high grade fertilizer, such as "Bowkers" in drill, mixing with the soil. For Fall use sow in August, and for Winter crop in September. Cover what you have left over with straw or leaves after the ground is frozen Sow seeds of New Zealand variety in hills, 2 feet apart each way, 3 or 4 seeds in hill.

All varieties, Pkt. 5c., oz. 15c.

Victoria. Large, very dark green leaves, slightly crimpled. Remains in good condition a long time. A new variety which is becoming a great favorite with market gardeners.

King of Denmark. Leaves dark green and thick. Not inclined to run to seed for a long time. Excellent for market gardeners.

Prickly Winter. Use for Fall sowing as it is extremely hardy. Seed prickly. Leaves not so large as other varieties.

Bloomsdale, or Savoy Leaved. Of upright growth. Leaves curled and crimpled, thick and fleshy. Suitable for Fall sowing.

New Zealand. Yields an abundance of the tenderest Spinach during the hottest part of Summer, or in dry localities where ordinary Spinach runs to seed. Cut leaves as fast as produced and it will keep right on growing.

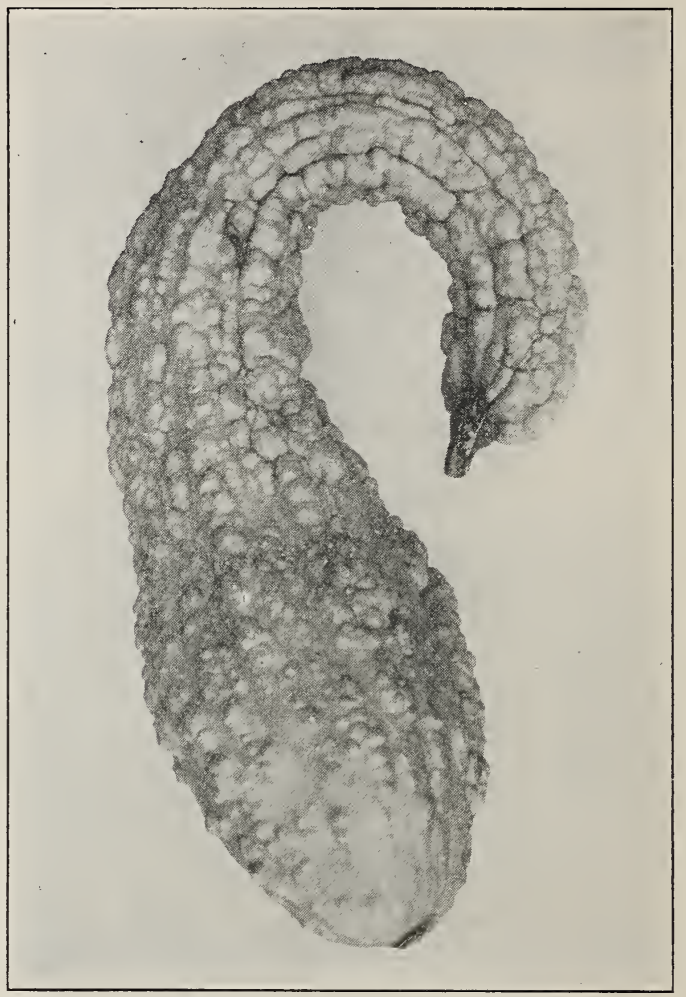

Early Summer Crookneck Squash

\section{SQUASH}

German, Kurbiss.

Italian, Zucca.

One ounce of seed for 25 to 40 hills (according to size of seed). 3 to 4 pounds per acre.

Culture.-Squash do best in warm, rich soil. Plant in well manured hills, same as for Melons or Cucumbers, the bush varieties 4 feet apart each way and the Winter sorts 8 to 10 feet, five to seven seeds in a hill. When danger from insects is past thin to three or four plants per hill.

\section{EARLY SUMMER VARIETIES}

Early White Bush. An early, round, flat Squash, handsomely scalloped. Color is clear white. Largely planted; one of the best early varieties. Pkt. 5c., oz. 15c.

Early Summer Crookneck. A well known and standard variety. Grows from 18 inches to 2 feet long. Best when picked small and tender. Shell is yellow and warted; flesh is thick and good quality. Pkt. 5c., oz. 15c.

English Vegetable Marrow. For summer and early Fall use. Oblong, shell cream color, flesh white. Pkt. 5c., oz. 15c.

Fordhook. (Vining). Small oblong variety, excellent for summer or winter. 8 to 10 inches long. Yellow, dry and and sweet. Pkt. 5c., oz. 15.

Italian Vegetable Marrow (Cocozella). Summer variety. Bush habit. Oblong, 16 inches long, color dark green with yellow and green stripes. Pkt. 5c., oz. 15c. 


\section{FALL AND WINTER VARIETIES}

Warted Hubbard. A favorite Winter Squash. Shell dark green and hard and warted; flesh, rich orange, dry and sweet. Splendid for cooking or pies. Pkt. 5c., oz. 15c.

Golden Hubbard. Earlier then the green Hubbard and a little smaller. Color, orange-red. Pkt. 5c., oz. 15c.

Boston Marrow. A good keeper and excellent flavor. Flesh is orange colored and fine grained; oval shape. Excellent for Winter use and canning. Pkt. 5c.. oz. 15c.

\section{TOMATO}

German, Leibesapfel. Italian, Pomo d'oro.

Culture.-Sow in hotbed, greenhouse or window in sitting room where night temperature does not go below 60 degrees, about the first of March, in drills 5 inches apart and $1 / 2$ inch deep. When plants are 2 inches high, transplant into paper pots or small boxes one to a box. Set in open ground when all danger of frost is past and ground is warm. Plant 3 feet a part in hills in which a liberal amount of sheep manure has bcen mixed. Set deep and water when transplanting. By training the Tomato vines on trellises or stakes, it will ripen better and be of finer quality.

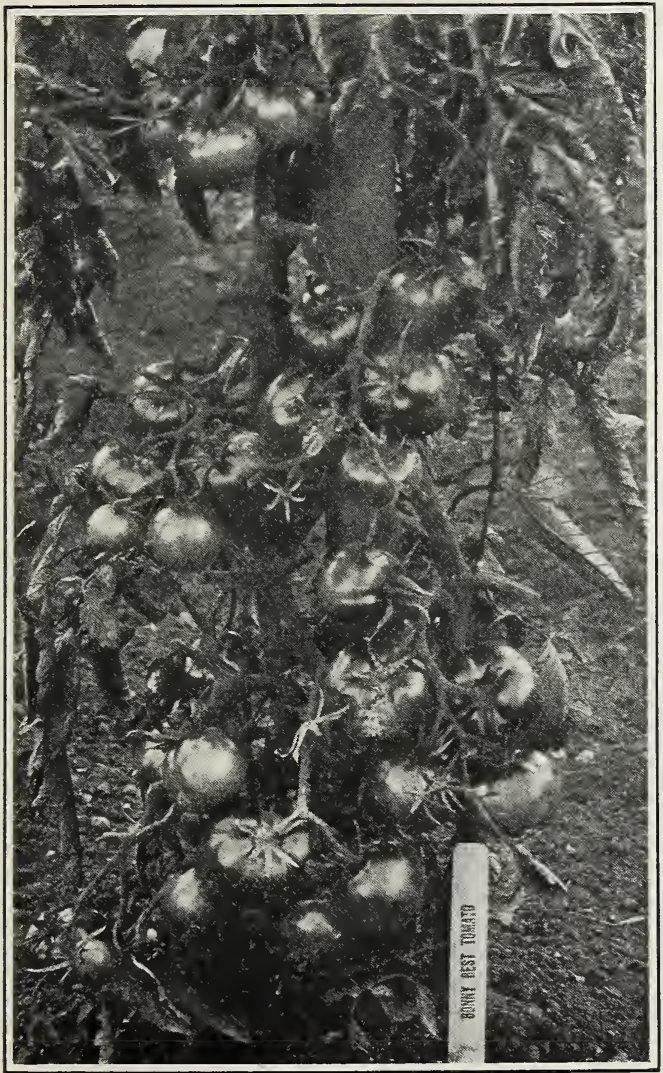

Bonny Best Tomatoes
Earliest Producer. This Tomato has shown wonderful results wherever grown last season. Always a prize winner for its shape, size and color. Good packer and shipper. Plants bear 40 per cent. more than other varieties. A very early ripening Tomato. Earlier and heavier producer than strains previously offered. Very resistant against blight. We have secured a limited quantity of this Earliest Producer Tomato seed and offer it as follows: Pkt. 10c., oz. $\$ 1.00$.

Acme. Ripens early, of medium, uniform size, round and smooth, pinkish in color. An excellent Tomato for the market gardeners. Pkt. 5c., oz. 35c.

Bonny Best. Ripens very uniformly; fruit is scarlet very solid and good interior color. vines are vigorous and produce a good crop of round fruit of excellent quality. Pkt. 5c., oz. 40c.

John Baer. An extra early scarlet fruited variety of superior merit. Vines hardy and productive. Largest of the extra early sorts and attractive in color. Nearly round, firm and smooth. Pkt. 5c., oz. $40 \mathrm{c}$.

June Pink. The earliest of the pink varieties and one of the best for the family garden. Skin is thin and smooth, and flesh is solid, of excellent quality and flavor. Pkt. 5c., oz. $45 \mathrm{c}$

Earliana. A fine scarlet Tomato; ready for the market very early; ripens uniformly and is a good yielder. Pkt. 5c., oz. 40c.

Chalk's Early Jewel. Fine, largè, smooth and scarlet. Similiar to Stone and early. Pkt. 5c., oz. $40 \mathrm{c}$.

Early Detroit. An early variety, better than Acme. Produces more fruits which are globeshaped, pink, heavy and firm. Holds its size well throughout the season. Pkt. 5c., oz. $45 \mathrm{c}$.

Dwarf Champion. Sometimes called "Tree Tomato." A second early pink variety. Desirable where space is limited. Vines grow about $2 \mathrm{ft}$. high; fruit smooth, medium size, and good quality. Pkt. 5c., oz. 45 c.

Ponderosa. A very large, solid Tomato. Color is pink, changing to a purple. Grown for exhibition on account of its large size. Of excellent quality and used in home gardens as it is quite mild in flavor. Pkt. 5c., oz. 50c.

Stone. Fruits are large and smooth, deep scarlet in color, and ripening evenly; meat is solid and firm. Very productive, a valuable variety for family use and for canning. Pkt. 5c., oz. 35c.

\section{SMALL FRUITED TOMATOES}

Yellow Plum, Yellow Cherry, Red Cherry, Red Pear, Yellow Peach, Strawberry or Husk. Used for preserving also for garnishing salads. Very mild in flavor. Pkt. 5c.

\section{TOBACCO}

German, Tobak Italian, Tabacco

One ounce of good seed is sufficient for 1 acre.

Culture.-Sow seed as early in Spring as possible after danger of frost is past. When plants are 6 inches high, transplant into rows 3 to 4 feet apart, with good space between plants.

Havana. We offer a very fine quality of Cuban grown seed of excellent flavnr. Pkt. 10c., oz. 40c. 


\section{TURNIP}

German, Weisse-Rüben.

Italian, Navone.

One ounce will sow 200 feet of drill. 11/2 to 2 pounds per acre.

Culture.-While Spring plantings of Turnip are important, the general or main crop is sown in late Summer or early Fall. Spring sown seed germinates very early and Turnips mature quickly. Do best on new ground. If manure is applied do it 3 to 4 weeks before planting, as it makes Turnips spotted. Sow in drills 12 to 15 inches apart and cover lightly. Thin to 6 inches apart in rows. For Fall and Winter use sow in July and August. Rutabagas are sown for stock feeding as well as for table use. Take up in November or before heavy frost, cut tops within 1 inch of crown and store in cool cellar or pit.

All varieties: Pkt. 5c., oz. 15c.

Extra Early Purple Top Milan. Best for Spring sowing. Of handsome appearance; somewhat flattened, white with purple top. Grows very rapidly.

Early White Milan. Similar in shape and size to the above and equally early. Surface smooth and white. Fine table quality.

Early Flat White Dutch. A popular early, white flat Turnip of medium size, smooth and of good quality.

White Egg. A good early, oval-shaped Turnip. Grows partly out of the ground. White, smooth skin, mild and sweet.
Purple Top White Globe. A fine table Turnip. Early and a heavy producer. Especially suitable for the home garden. Also a good Turnip for stock feeding as it will grow to large size if left in the ground until late.

Purple Top Strap Leaf. Probably the most extensively planted variety of Turnip. It is early, flat and of medium size, the lower portion white and upper part reddish purple. A fine table variety; flesh fine grained and sweet.

Snowball, or Six Weeks. A fine, pure white variety, maturing in six to seven weeks. Has a smooth, white skin and is nearly round. Does not grow very large but is one of the best early Spring sorts. Very tender and sweet.

Yellow Globe. One of the best yellow Turnips for general crop. Has a smooth skin and light yellow flesh, firm and sweet. Grows to large size. Is excellent for table use or for feeding stock. Keeps well until late in the Spring.

\section{RUTABAGA}

Culture.-Same as Turnip, only make rows at least 2 feet apart, and have plants 8 to 10 inches apart in rows.

All varieties: Pkt. 5 c., oz. 15c.

American Purple Top. Hardy, vigorous growing variety of excellent quality and one of the best for stock feed. Grows to a large size.

White Swede, or Russian. A large, white, globe-shaped variety. Flesh is fine quality, sweet and tender. Excellent for the table. May be grown to large size for stock feed.

\section{Seeds of Pot, Sweet and Medicinal Herbs}

The cultivation of herbs is very simple, as they need but little care beyond keeping down the weeds. Sow in early Spring in drills 12 to 15 inches apart and thin out young plants so they will not stand too thickly. Gather when just coming to bloom. Tie in bunches and dry in shade.

\section{All varieties: $\mathbf{P k t}$. 5c.}

Anise. Seed aromatic and caminative.

Caraway. For sowing. Used in flavoring and bread.

Coriander. Seeds aromatic. For sowing.

Dill. For flavoring pickles.

*Fennell. Seeds aromatic. For flavoring.
*Lavender. For flavoring, also for distilled toilet water.

Marjoram, Sweet. Used for seasoning.

Savory, Summer. Used as a culinary herb.

Sage. Broad leaved. A culinary herb.

Thyme.

Varieties preceded by * are perennial.

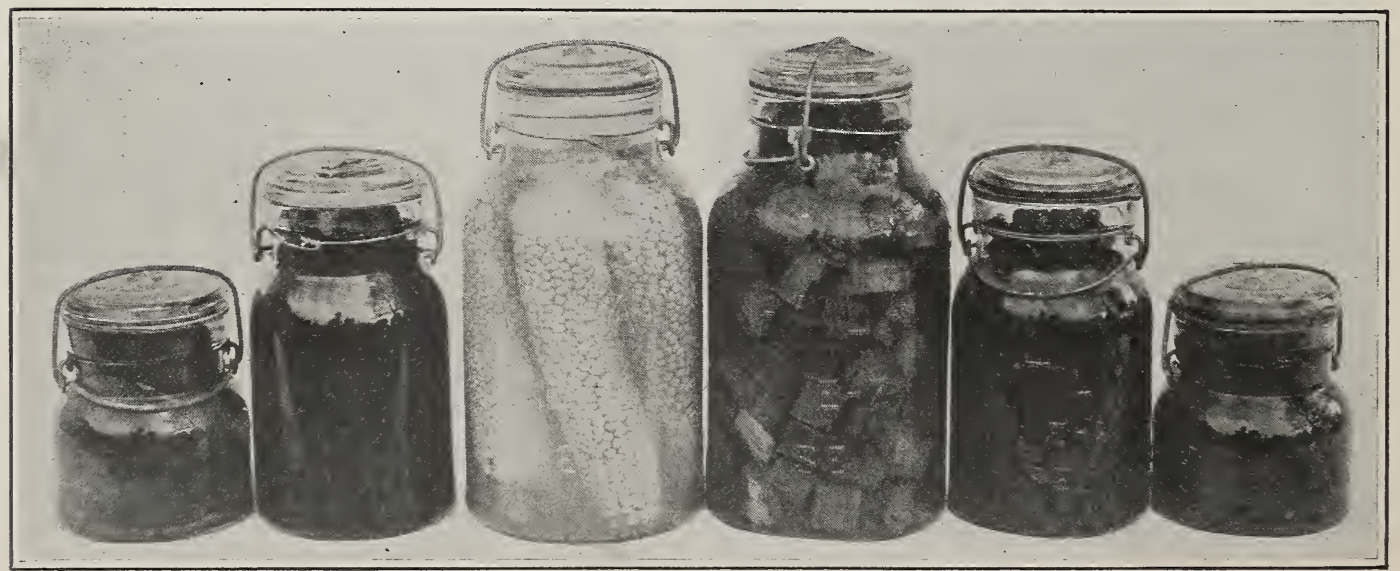

Can vegetables for winter use - from your own garden 


\section{Vegetable Plants and Culinary Roots}

We grow Vegetable Plants in large quantities and have them fresh every day in season. We offer the following:

Asparagus Roots

Brussels Sprouts

Cabbage, Early Varieties

Cabbage, Late Varieties

\section{Cauliflower}

Celery

Egg Plant

Horse Radish Sets

Kohl-Rabi

\section{Pepper}

Rhubarb Roots

Tomato, Pot Grown

Tomato, Transplanted

Market prices given upon application.

\section{Strawberry Plants}

After considerable experience with many varieties we have decided to stock the Peerless Everbearing Strawberry Plants. They are hardy, large, strong rooted plants and bear heavily. Not only will they give you Summer berries, but will also produce plentiful crops during the early Fall months. Those who have used our plants pronounce them "unexcelled," both in vigor of bloom and quality of fruit. Price, 25 plants $\$ 1.00,100$ plants, $\$ 3.00$.

We also furnish other standard varieties such as Ryckman, Brandywine, Ozark, Marshall, Dunlap, etc., etc., on order.

\section{0 \\ Annual Flower Seeds General Cultural Directions}

It is an excellent plan to mix all small seeds with sand or dry soil, and sow the mixture in drills or scatter broadcast. This separates the seed and makes it easy in thinning out or transplanting. A common mistake is the sowing of flower beds too deeply. As a general rule cover small seeds only to the thickness of the seed. With medium size seeds, such as Balsam, Zinnias, etc., cover only one-half in depth of the thickness of the seed. Such fine seeds as Petunias, Portulacas, etc., need only to be pressed into the soil with a board. Always press the soil after sowing all flower seeds. Seeds of the hardier annuals may be sown where they are to grow, but as a rule it is well to transplant as it makes the plants stronger and able to stand dry spells better. Keep all weeds down and the ground loosened often.

Hard Shelled Seeds, such as Canna, Japanese Morning Glory, Moonvine, Wild Cucumber, etc., should be soaked in warm water thirty-six hours before planting. Some of the varieties of seeds listed in our catalogue require or are benefitted by special handling and you will find these cultural directions in connection with the descriptive matter covering them.

ACROCLINIUM. Very pretty annual, "Everlasting," about 12 to 15 inches. Has white or rosypink flowers. When cut in bud and dried are good for Winter bouquets. Excellent in mixed border. Double mixed. Pkt. 10c.

\section{AFRICAN DAISY. (See Dimorphotheca.)}

AGERATUM (Floss Flower). Hardy annual. Easily grown and blooms until frost. Mix seeds with sand to prevent sowing too thickly. A fine bedding plant. Blue flowers.

Mexicanum. Lavender blue. Pkt. 10c.

Blue Perfection. Darkest color, compact growth. Pkt. 10c.

AL YSSUM (Madwort). Pretty little plants for bedding and edging in rock work. Blooms freely all Summer. Sow where seeds are to remain. Mix seed with sand to prevent sowing too thickly.

Maritimum (Sweet Alyssum). White. Pkt. 5c.

Little Gem, or Carpet of Snow. Dwarf or trailing habit. Pkt. 5c.

Tom Thumb. Dwarf compact habit, excellent for edging. White. Pkt. 5c.

Lilac Queen. A deep lavender lilac shade, dwarf, compact habit. Pkt. 10c.
AMARANTHUS. 3 to $5 \mathrm{ft}$. Annuals with brilliant foliage. Useful in borders or for center of large beds. Like a hot, sunny spot, not too rich. soil and plenty of room to grow to full size and beauty

Caudatus (Love Lies Bleeding). Blood red, drooping. Pkt. 5c.

Tri-Color (Joseph's Coat). Foliage crimson, yellow and bronze. Pkt. 5c.

Sunrise. Foliage bronze-crimson with tuft of scarlet leaves at end of branch. Pkt. 10c.

ANTIRRHINUM (Snapdragon). One of the best cut flowers and easily grown from seed. Succeed best in sunny location and rather light soil. Best treated as an annual, although it will frequently live through the Winter if protected.

Dwarf Varieties:

Tom Thumb, Mixed Colors. Pkt. 10c.

Semi-Dwarf Varieties:

White, Pink, Yellow, Carmine and Mixed. Pkt. 10c.

Giant Flowering Varieties:

White, Pink, Carmine, Yellow and Mixed. Pkt. 10c. 
ASPARAGUS.

Plumosus nanus. (Asparagus Fern.) A very graceful table fern with delicate, lace-like foliage. 10 seeds, $15 \mathrm{c}$., 100 seeds, $\$ 1.00$.

Sprengeri. (Emerald Feather.) Excellent for hanging baskets and for outside window boxes. 10 seeds, 15c., 100 seeds 50c.

ASTERS. General cultural directions. Sow in April indoors or in a coldframe in pots or flats. Transplant 1 in. apart, when they have made third leaf. Plant out in late May or early June. Soak the ground with Vermine before planting to rid it of all grubs, etc., that attack and destroy young plants. A later sowing may be made outdoors in May.

Semple's Late Branching. 16 inches and up. Beautiful for cut flowers. Flowers large, verydouble, on long, stiff stems, and colors clear and handsome. White, pink, rose, red, lavender, dark blue and mixed. Pkt. 10c.

Ostrich Plume. Tall, 16 in. and up. A fine type of the Giant Comet, but larger. Petals are long and twisted and produced in great abundance. Have long stems and are fine for cutting. White, pink, rose, red, lavender and dark blue and mixed. Pkt. 10c.

Queen of the Market. Half tall, 11 to 16 in. The best early Aster, usually in bloom two weeks before most other sorts. Of graceful spreading habit. White, pink, rose, red, lavender, dark blue and mixed. Pkt. 10c.

King Aster. 16 in. and up. Similar in habit to the Giant Branching. with long, stiff stems, petals resembling the quilled varieties, but longer and broader, center petals being curled and incurved, covering the crown. The bloom is round, full and very large, White, rose, red, lavender, pink, pink, dark, blue, mixed. Pkt. 10c.

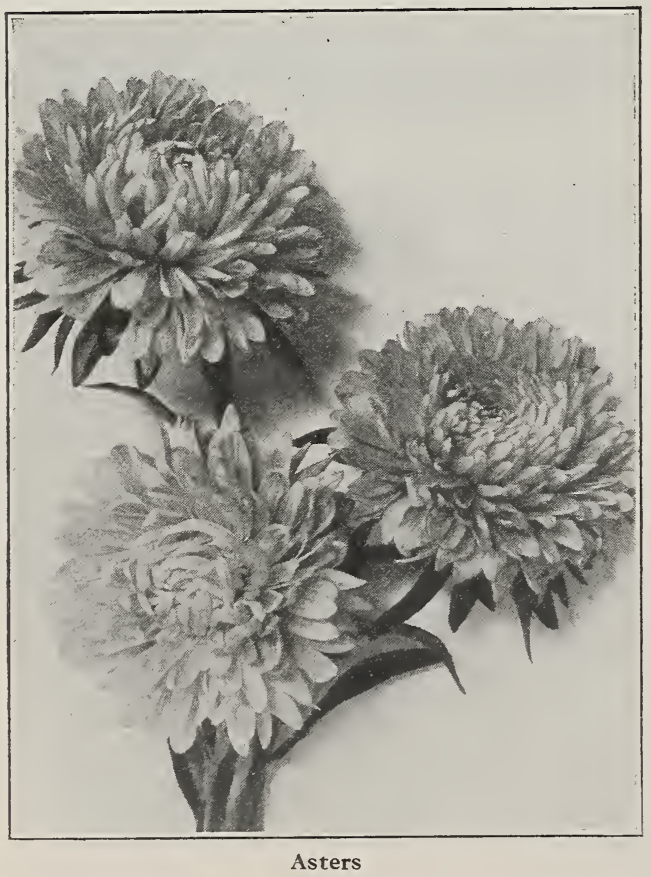

Daybreak. Half tall, 10 to 16 inches. A strong, bushy plant of even growth,. with full, round flowers on strong, stiff stems. Valuable for bedding. White, rose, lavender, pink, dark blue, mixed. Pkt. 10c.

\section{BACHELOR BUTTONS. (See Centaurea.)}

BALLOON VINE (Love in a Puff). A free growing, clean cut vine, 10 to $15 \mathrm{ft}$., with delicate clusters of bloom and large, round seed pods, resembling miniature inflated ballons, very odd and curious. A very effective vine. Pkt. 5c.

BALSAM, Double (Lady Slipper). A favorite garden flower. Produces gorgeous masses of beautiful and brilliant double flowers in profusion. They like the hot sun and plenty of water. Set 12 to 18 inches apart. Transplanting several times dwarfs the plants to better shape and makes the flowers more double.

Double Camellia Flowered. White, salmon, Prince Salfino (Striped and spotted white, lilac and scarlet), violet, scarlet and mixed. Pkt. 10c.

BEANS, Ornamental (Scarlet Runner). An exceedingly rapid grower, its strong vines being covered with bright, scarlet flowers from early Summer till Fall. Pick pods as formed to help bloom. Pkt. 10c.

BRACHYCOME (Swan River Daisy). $1 \mathrm{ft}$. A dwarf, free flowering annual. Bears a profusion of pretty blue or white Cineraria-shaped flowers the greater part of the Summer. Fine for edging small beds or for pots. Pkt. 10c.

CALENDULA (Pot Marigold). $1 \mathrm{ft}$. One of the showiest and bestfreefloweringannuals. Fineinmixed borders or beds. Continues in bloom from early Summer until frost. Valuable for pot culture in Winter and early Spring.

Orange King. Color a glowing orange. Pkt. 10c.

Lemon Kins. Large and sulphur yellow. Pkt. 10c. Mixed Double. Pkt. 10c.

CALLIOPSIS (Tickseed). $11 / 2$ to $2 \mathrm{ft}$. Splendid border plants, greatly prized for bouquets and vases. Will grow anywhere and their bright flowers are greatly prized, especially in city gardens.

Mixed. Containing all the most desirable sorts. Pkt. 10c.

CANARY BIRD VINE. 15 to $20 \mathrm{ft}$. A dainty vine with beautifully cut leaves and delicate canaryyellow flowers. These resemble a bird with wings outstretched. Does well in shade. Pkt. 5c.

CANDYTUFT. Especially adapted for massing in beds and borders, also for edging. Strong bloomers and fine for cutting.

Giant Hyacinth, Flowered. White. $1 \mathrm{ft}$. Finest of all white varieties. Pkt. 10c.

Lilac, Crimson, Rose Carmine, Mixed. Pkt. $10 \mathrm{c}$.

CARDINAL CLIMBER (Ipomoea quamoclit Hybrida). $25 \mathrm{ft}$. A very strong growing and attractive vine. Beautiful, fern-like foliage and covered with fiery-red cardinal flowers, 1 in. in diameter, in clusters. Wants warm, sunny location. Plant outdoors about May 20th. Soak seed in water for several hours to hasten germination. Pkt. 10c.

CARNATION. A handsome hardy border flower. Free flowering and easily grown in beds, borders or pots. 
Chabaud's Everblooming Mixed. A beautiful strain, originating in Southern France. Double flowers in great profusion. Pkt. 10c.

Marguerite. Mixed. Double flowers of large size and all colors; upright growth. Hardy if protected. Pkt. 10c.

CASTOR OIL BEAN. (See Ricinus.)

CELOSIA (Cockscomb). Very popular, easily cultivated annuals, having large, ornamental comblike heads. Fine for Summer flower beds. Quickly produced from seed.

\section{Cristata, or Crested.}

Tall Mixed. Crested. Pkt. 10c.

Dwarf Mixed. Pink, yellow and golden crested. Pkt. 10c.

Thompsoni magnifica. Plumed. Colors from light yellow to dark red. Pkt. 10c.

Plumosa aurea. Golden Plumed. Pkt. 10c

Plumosa Childsii (Chinese Wool Flower). Plants 2 to $3 \mathrm{ft}$. high. Starts bloom early, each branch bearing a ball of scarlet wool. These mixed with the green foliage resemble a huge bouquet. Bloom full until frost. Pkt. 10c.

CENTAUREA. Popular annuals such as Cornflower, Sweet Sultans, Bachelor Buttons, are included under this title. All are attractive flowering and of easiest culture.

Bachelor Buttons (Blue Bottle, Ragged Sailor), etc., Single. Pkt. 5c.

Double Blue and Mixed Colors. Pkt. 5c.

Yellow Sweet Sultan (Suaveolens). Pkt. 5c.

Imperialis Sweet Sultan. White, lilac, rose and mixed. Pkt. 10c.

Gymnocarpa (Dusty Miller). Fine cut, silvery foliage. Much used for borders. Pkt. 10c.

Candidissima. Silvery white leaves broadly cut Pkt. 10c.

CHRYSANTHEMUM (Painted Daises). $21 / 2 \mathrm{ft}$. Annual single, and double, mixed. Showy and effective garden favorites and grown for cut flowers. Come in many colors. Splendid Summer flowering border plants. Distinct from the perennial and Fall flowering varieties. Pkt. 10c.

CLARKIA. $2 \mathrm{ft}$. A popular Summer annual, perfectly hardy and will grow easily in ordinary soil. Bloom profusely and are bright and attractive, especially in large masses.

Elegans, Double Mixed. A fine mixture, containing all colors from white to purple. Pkt. 10c.

GLEOME pungens (Spiderwort). $5 \mathrm{ft}$. A showy garden annual, well branched with large heads of bright, rosy-crimson blossoms. Fine for large beds or in between shrubbery. Sow seed early in open ground as soon as weather is warm and settled. Give plants plenty of room. Pkt. 10c.

COB EA scandens (Cathedral Bells). $30 \mathrm{ft}$. A very handsome and rapid growing climbing vine. Flowers are bell-shaped, opening a clear green, but turning to a deep puprlish-blue. Plant seed edgewise. Pkt. 10c.

Flora alba. Same as above, with white flowers. Pkt. 10c.

Mixed. Blue and white. Pkt. 10c.

COLEUS. Mammoth Rainbow mixed. Handsome foliage plant. The color combinations are remarkably fine. A splendid border plant or for veranda boxes. Pkt. 10c.
COSMOS. Beautiful Autumn flowering plants, and producing flowers in white, crimson and pink shades. Fine for cut flowers in the Fall when other flowers are scarce. Sow in the Spring when danger of frost is past. Plant about 18 in. apart. When $1 \mathrm{ft}$. high pinch tops to induce bushy growth. Soil should not be too rich. Early flowering sorts are preferred for this location.

Double Pink. Early.

Double White. Early.

$\$ 0.10$

10

Double Red...................... . . . . . . .

Early Mixed......................... . . . . . .

Crimson. Early .................. 10

Pink. Early........................ 10

Klondyke, Yellow................... . . . . .

Lady Lenox. Pink, late................... . . . . . .

Lady Lenox. White, late............... . 10

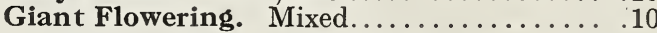

GYPRESS VINE (Ipomoea quamoclit). $15 \mathrm{ft}$. A very popular vine with delicate, fern-like foliage and numerous star-shaped flowers. Sow in May, first soaking seeds in warm water for several hours.

Mixed Colors. White and scarlet. Pkt. 10c.

DAHLIA. $4 \mathrm{ft}$. Dahlias can be grown from seed and will bloom the first year. Seed germinates easily. Plant in shallow box in March or April. Transplant to pots, and set outdoors when all danger of frost is past. Many pleasing and new colors and shapes may be obtained from seed.

Double and Single Flowering, Mixed. Pkt.10c.

DATURA (Trumpet Flower) (Angel's Trumpet). 2 to $3 \mathrm{ft}$. Handsome, showy plants, with large trumpet-shaped, fragrant flowers. Need a light soil, and warm, sheltered location. Make a good pot plant for greenhouse.

Cornucopia (Horn of Plenty). Large flowers, like three cones, one within the other. Color rich violet with white interior. Dig root and protect from frost. Pkt. 10c.

DIANTHUS (Garden Pinks). Annual varieties of these popular garden flowers. Flowers are brilliant, the contrasting variety of colors in flowers make them stand out distinctly. Not particular as to soil, but must have sunny location. Will survive if protected.

Heddewigii (Japanese Pinks). Single Mixed. Pkt. 10c. Double Mixed. Pkt. 10c.

Chinensis (India, or Chinese Pink). Large, double, fragrant flowers. Mixed colors. Pkt. 10c.

Laciniatus (Fringed Pink). An annual double fringed pink, very showy. Mixed colors. Pkt. 10c.

DIDISCUS. (Blue Lace Flower). Pretty pale lavender blooms excellent for cutting. Very free blooming. Pkt. 10c.

DIMORPHOTHECA (African, Golden or Orange Daisy). 12 to 15 inches.

Aurantiaca. Hardy annual from Africa. Plants bushy. Flowers are $21 / 2$ inches and over. Rich, glossy, orange-gold with dark center surrounded with black zone. Pkt. 10c.

DOLICHOS. (See Hyacinth Bean.)

DRACENA indivisa (Dragon Plant). Popular plants for pots or vases. Not hardy; long, narrow green leaves. Pkt. 10c. 
ESCHSCHOLTZIA (California Poppy). $1 \mathrm{ft}$. Very attractive annuals for edging or masses in beds. Fine cut, feathery foliage; profuse flowering, in bloom from June till frost. Bright, showy flowers. We offer a very fine selection of mixed colors from soft flesh pink to brilliant scarlet. Easily grown. Fine for cut flowers, cut in bud. Pkt. 10c.

EVERLASTINGS. (See Helichrysum.)

\section{FLAX. (See Linum.)}

EUPHORBIA. Variegata. Snow on the Mountain. A very showy plant with green foliage edged with green and white. Pkt. 10c.

FOUR O'GLOCK. (See Marvel of Peru.)

FORGET-ME-NOT. (See Myosotis.)

GAILLARDIA (Blanket Flower). 11/2 ft. Showy annuals, in bloom from early Summer till Fall. Brilliant colors, red and yellow predominating. Excellent for beds, borders and for cutting. Sow where they are to bloom. $10 \mathrm{c}$.

Lorenziana, Double Perfection Mixed. Pkt.

GOMPHRENA (Globe Amaranth). $2 \mathrm{ft}$. Hardy annual flowers, with red, clover-shaped blossoms; cut when in full bloom and dried they retain their beautiful coloring. Pkt. 5c.

GODETIA. $1 \frac{1}{2} \mathrm{ft}$. A very attractive, hardy annual and one that should be more extensively grown. Plants bloom freely and bear showy Azalea like flowers of satiny texture in rich and varied colors. Does hest in a rather poor soil.

Mixed Colors. Pkt. 10c.

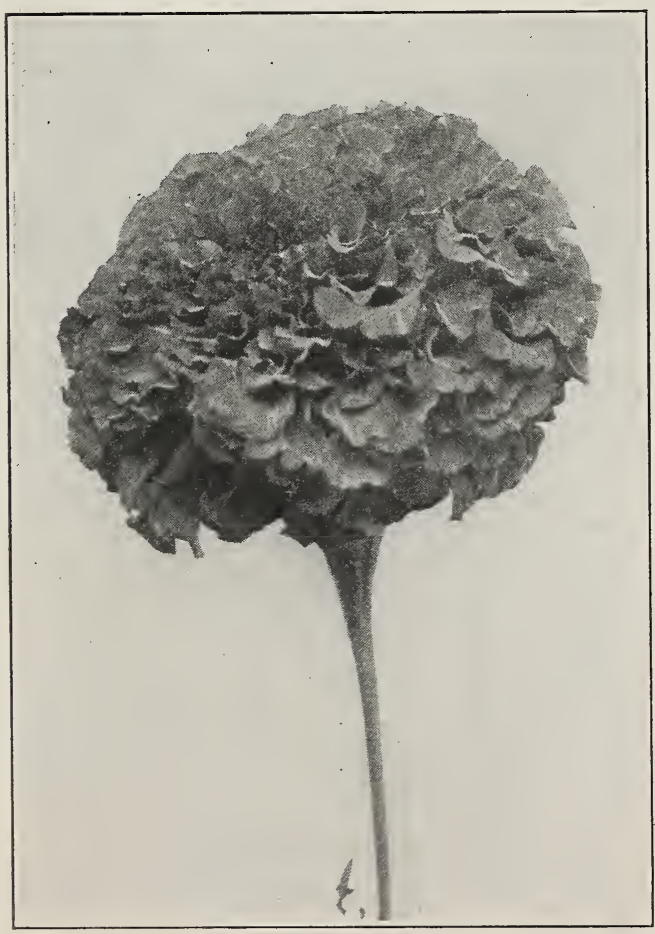

Marigold-See page 21
GOURDS. $20 \mathrm{ft}$. Quick growing vines for covering arbors, walls and trellises. Blossoms of many are striking and handsome. The fruits are of all sizes and shapes. Many of them curiously shaped and marked. Dishcloth, Apple, Pear, and Orangeshaped, Calabash, Sugar Trough, Nest Egg, Bottle, Dipper.

Mixed Varieties. Pkt. 5c.

GYPSOPHILA (Baby's Breath). $2 \mathrm{ft}$. Graceful plants much in demand for cutting and combining with other flowers in bouquets. Make several sowings during the season to keep up the supply.

Elegans, grandiflora alba. White. Pkt. 5c.

Mixed. Pink, white and carmine. Pkt. 5c.

HELIANTHUS (Sunflower). Grown extensively for brilliant effects; tall and imposing. They make a background for other lower growing plants and for filling waste spaces. The seed is extensively used for poultry.

Mammoth Russian. Pkt. 5c.

Common or Garden Variety. Pkt. 5c.

Double Hybrids. Pkt. 10c.

Minature. Single and Double Mixed. Pkt. 10c.

HELICHRYSUM (Strawflower), 2 to $3 \mathrm{ft}$. An ornamental plant for the garden when growing and also much prized for Winter bouquets. If intended for drying flowers should be gathered when partially open and dried in a cool place with heads downward.

Rose Carmine. Pkt. 10c.

Bright Red. Pkt. 10c.

Golden Yellow. Pkt. 10c.

Mixed. Pkt. 10c.

HELIOTROPE. A universal favorite because of its delightful fragrance and long blooming period. Equally good as bedding plants in Summer and pot plants in Winter. Easily grown. Seed sown indoors in early Spring make fine bedding plants.

Finest Mixed. Light and dark shades. Pkt. 10c.

HUMULUS japonicus (Japanese Hop). Variegated foliage. $20 \mathrm{ft}$. Rapid Summer climber. with dense foliage. One of the best annual vines for covering verandas, trellises, etc. Heat, drought and insects do not trouble it. Pkt. 10c.

HYACINTH BEAN (Dolichos). $10 \mathrm{ft}$. Rapid growing climber with pretty foliage and bean-like flower. Desirable as a cover for porches, trellises, etc. Sow seed in a sunny spot late in May.

Princess Helen. (Daylight.) White. Pkt. 10c.

Purple Soudan (Darkness). Rose violet flowers and dark, ruby-purple seed pods. Pkt. 10c.

Fine Mixed. Pkt. 10c.

KOCHIA (Summer Cypress) (Burning Bush) $21 / 2$ feet.

Tricophylla. An easily grown annual sown in the Spring. Grows quickly and makes a Cypresslike hedge of beautiful green. Late in the Autumn it becomes a deep red. A splendid plant for dividing the vegetable garden from the flower garden, or for quick growing non-permanent hedge. Pkt. 5c.

KUDZU VINE (Jack and the Bean Stalk). 8 to $10 \mathrm{ft}$. A very fast-growing hardy climber. Easily started from seed. Foliage is large and has rosypurple, pea-shaped blossoms late in the season. Makes a splendid permanent cover for verandas, trellises, etc. Pkt. 10c. 
LANTANA. $2 \mathrm{ft}$. A very desirable, half hardy perennial plant for bedding or greenhouse. A constant bloomer. Verbena-like flowers in white, red and yellow shades, and having an agreeable, aromatic odor. May be grown in pots and set out in Summer. Pkt. 10c.

LARKSPUR. Annual. $2 \mathrm{ft}$. One of the best known garden annuals. By careful selection it has been greatly improved in the color and size of the blossoms. Sow in the open ground in early Spring. Will produce flowers from July until frost. Splendid for beds or among the shrubbery. Also excellent for cutting.

Double Stock Flowered, Mixed Colors. Pkt. 10c

\section{LINUM (Flax).}

Grandiflorum rubrum (Scarlet Flax). A very effective and showy bedding plant, with fine foliage and scarlet-crimson flowers. $1 \mathrm{ft}$. Pkt. $10 \mathrm{c}$.

LOBELIA. A popular and beautiful plant for pot culture, edgings, ribbon bedding, hanging baskets, etc. Fully covered with bloom all Summer and until frost. Sow seed out of doors where plants are to grow. A stimulant given them when in bloom greatly improves the flowers. Are good Winter conservatory plants of trailing habit.

Erinus compacta. Crystal Palace. Deep rich blue, dark foliage. Best dark blue for bedding. 6 inches. Pkt. 10c.

Gracilis. Light blue flowers, light green foliage, trailing habit. Pkt. 10c.

Emperor William. Dwarf. Light blue. Pkt $10 \mathrm{c}$.

\section{LOVE-IN-A-MIST. (See Nigella.)}

LUPINUS (Lupine). $2 \mathrm{ft}$. Free flowering, easily grown annuals with long, graceful spikes of rich, variously colored, pea-shaped flowers. Excellent for mixed beds, borders and for cutting. Prefers a little shade.

Mixed Colors. Pkt. 10c.

MARIGOLD (Tagetes). 1 to $2 \mathrm{ft}$. Valuable because of their rich colorings of yellow and gold, from mid-Summer until frost. The dwarf varieties make a fine border for the tall ones. The African varieties have large, self-colored blossoms. The French are smaller and are striped and spotted.

Pkt.

French Dwarf, Double Mixed .......... \$0.10 French Legion of Honor, Single......... . . 10 African Tall, Double Mixed............ . 10 African Orange Prince, Double......... . 10 African Lemon Queen, Double. . . . . . . . . . 10

MARVEL OF PERU (Mirabilis) (Four o'Clock). $2 \mathrm{ft}$. A good, old-fashioned annual flower. Forms a nice, bushy plant covered with hundreds of starshaped blossoms, white, yellow, crimson and violet, and spotted. Makes a good hedge plant for temporary planting.

Mixed Colors. Pkt. 5c.

MATRICARIA (Feverfew). $3 \mathrm{ft}$.

Capensis fl. pl. A fine bedding plant with small double white flowers. Fine for cutting or as a pot plant. Are a perennial in a mild climate, but treated as an annual here. . Pkt. 10c.

MIGNONETTE. A well known, fragrant garden favorite. Used for cutting and in bouquets with other blossoms: Sowings made in April and again in July, will give a succession of bloom from early Summer to frost. Can also be grown in pots for Winter flowering.
Defiance. Large spikes and deliciously fragrant. Fine keeping qualities. Pkt. 10c.

Machet. Dwarf. Best for all purposes, either for indoors or outdoors. Pkt. 10c.

Pyramidalis. Tall, large flowering. Pkt. 10c.

Miles Spiral. Dwarf. $1 \mathrm{ft}$. Pkt. $10 \mathrm{c}$.

MOONFLOWER (Ipomoea). $20 \mathrm{ft}$. Beautiful twining, rapid growing annual climbers. Foliage very dense and odd-shaped. Fine for indoor or greenhouse culture. As the seeds are slow to germinate, they should be notched with a file before planting.

Grandiflora. Covered with large white flowers every evening and on cloudy days. Start seeds indoors. Pkt. 10c.

\section{MORNING GLORY (Ipomoea).}

Imperialis (Japanese Morning Glory). Improved mixed. The Japanese Morning Glory requires a warm location to do best. The south side of a building is best. This variety is beyond question the best of all Morning Glory. Variegated form of foliage. Flowers of gigantic sizes and beautiful colorings. Pkt. 5c.

Dwarf Morning Glory. Very showy and beautiful. Hardy annual for bedding and borders, also rockwork. They have a long blooming period and blossom freely in sunny location. Mixed, all colors. Pkt. 5c.

Francy-Fringed. Rapid climbers, same as the Japanese varieties, only that the petals are fringed; very attractive and pretty. Pkt. 10c.

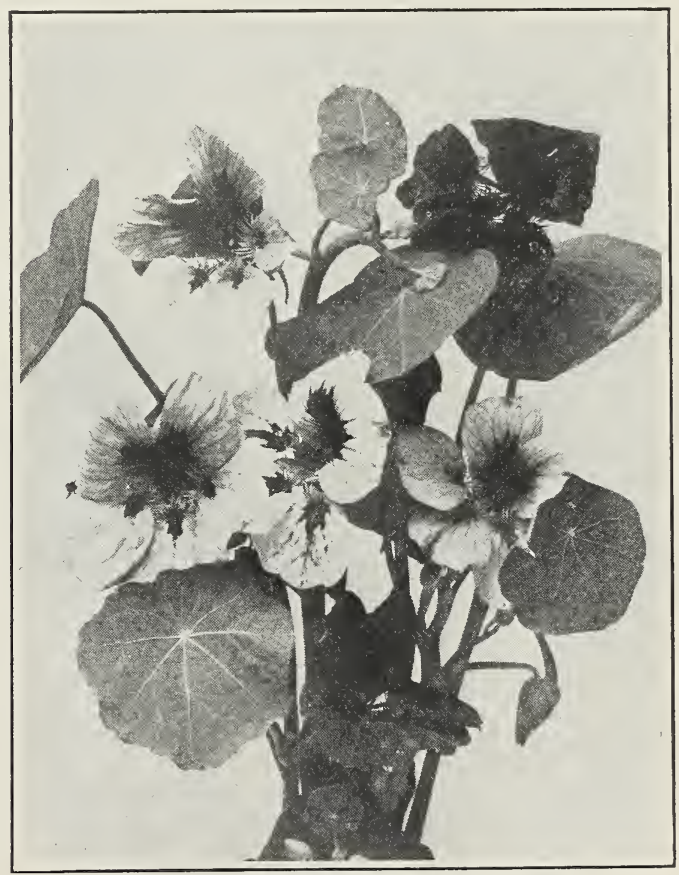

Climbing:Nasturtium-See page 22 
MYOSOTIS (Forget-Me-Not). $1 / 2 \mathrm{ft}$. to $1 \mathrm{ft}$. One of the best early Spring flowers, and make a splendid combination with Pansies and Daisies. They are especially effective when grown in masses. They are of a trailing habit. Best in shady, moist and cool location. Seed may be sown at any time in Spring or mid-Summer. Hardy if given slight protection during the Winter.

Alpestris. Royal blue, trailing habit. Pkt. 10c.

Dissitiflora. Rich blue, very early bloomer. Dwarf, compact habit and well adapted for planting among early Spring flowers. Pkt. 10c.

NASTURTIUM. Nothing excels Nasturtium flowers in duration of bloom. All they require is a moderately good soil and a sunny location. The dwarf varieties make excellent bedding or border plants. The tall varieties are luxurious climbers for veranda or covering railings or fences or for covering rough ground. Sow seed 2 in. deep and thin plants to 8 in. apart for dwarf varieties and 10 to 15 in. apart for tall and climbing varieties.

Special Mixture of Dwarf Nasturtiums. Pkt. 5c., oz. 15c.

Special Mixture of Tall Nasturtiums. Pkt. 5c., oz. 15c.

NICOTIANA (Tobacco Plant). 2 to $3 \mathrm{ft}$. Free blooming, half hardy annual. Flowers all Summer, tubular-shaped flowers.

Affinis (Tuberose-flowered Tobacco). Delightfully sweet scented white, flowers blooming continually. $\mathrm{Pk}$. 10c.

Sanderae Hybrids. A.splendid type in a great variety of colors. Pkt. $10 \mathrm{c}$

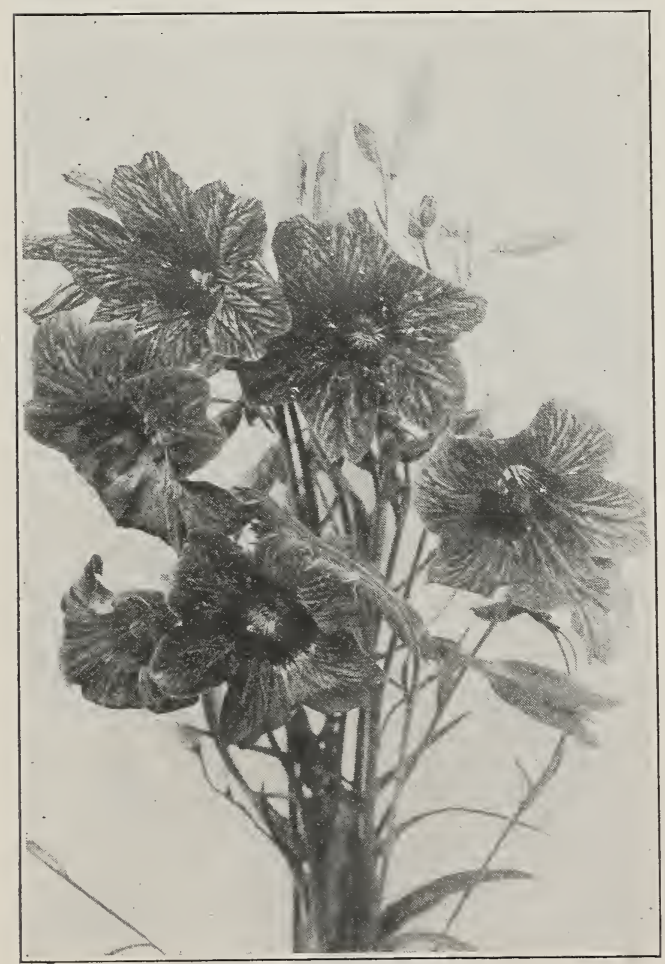

Salpiglosis-See page 23
NIGELLA (Love-in-a-mist). $1 \mathrm{ft} . \quad$ A hardy annual garden plant, easy culture. Fine cut foliage curious looking seed pods. Blue and white flowers. Grows in any good garden soil. Splendid for cutting. Mixed Colors. Pkt. 5c.

PANSIES. They are so well known that they do not require any description. Pansy seed germinates and the plants grow more freely in the early days of Spring and should, therefore, be sown in the latter part of April or early in May. Use good, rich soil composed of leafmold, well decayed cattle manure and good garden loam. Sow the seeds in drills, covering them not more than twice their diameter and pack the soil firmly over them. Bed may be covered with newspapers to hasten germination and prevent drying. About the middle of August is the best time for sowing Pansy seed for very early plants. Pansies are hardy and if covered with straw or leaves will Winter themselves and come out sturdy and strong in the Spring. We offer, Giant Trimardeau, as producing the largest and most beautiful blossoms in separate colors as follows:

Giant Golden Queen. Yellow.

Giant Lord Beaconsfield. Deep purple violet, shading to white.

Giant Snow Queen. White.

Giant Mixed. Pkt. 10c.

Masterpiece (Frilled Pansy). In a wide range of colors. Pkt. 25c.

Tufted Pansies, or Violas. Very free blooming in clear and distinct colors. Pkt. 10c.

Good Mixed. A splendid mixture of the best varieties. Pkt. 5c.

PETUNIA. A most pleasing display can be made with Petunias. Plants make a good strong growth and bloom freely until after hard frost. Petunia seed is a little difficult to germinate but it is not hard if a reasonable amount of care is used. Have the soil well pulverized. Sow seeds on the surface, pressing them into the soil, using a small, smooth board. Then cover lightly with sand or light soil. Seeds sown in a hotbed or in the house early in the Spring will produce flowering plants for June. Seeds of the double Petunia do not possess as much vitality as the single, neither will they all come double.

Howard's Star, Dwarf. Rich crimson, white star in the center; very showy. Pkt. 10c.

Rosy Morn (Nana compacta). Bushy, compact, medium size flowers, produced in great abundance. Colors bright pink with a broad white throat. Pkt. 10c.

Giant California. Flowers very large size, a great variety of colorings and markings with yellow throats. Colors are of almost every shade of crimson, white, lavender, etc. Pkt. 25c.

Double Fringed Mixed. Only a small percentage of the double are double. The reason for this is that the seed must be selected from the single flowers which have been pollinated with pollen from double flowers. Pkt. 50c.

Single Mixed. Pkt. 10c. 
PHLOX Drummondii (Flame Flower, Annual Phlox). $1 \mathrm{ft}$. One of the showiest and most easily raised of all annuals. Dazzling in effect and contrasting in colors, especially when sown in masses or ribbon beds. Produces a continuous supply of most attractive flowers in all possible varieties of stripes, veins, and eyes of many shades. Sow seeds out of doors as soon as danger of frost is past. Cutting flowers and seed pods make plants more bushy and lengthens blooming period.

Choice Mixed. Splendid, large flowering sorts. Pkt. 10c.

Cuspidata, Mixed (Star of Guedlingburg). Dwarf, with very pretty, star-shaped flowers. Mixed colors, Pkt. 10c.

POPPY. Annual Poppies are sown as early in Spring as possible in place where they are to remain, as they do not stand transplanting. Plant seed in succession two weeks apart for all Summer bloom. Mix seed with sand before sowing so as to distribute seed thinly and evenly.

Shirley. Best mixed singles; bright, dainty and gauzy. A favorite for cutting. Pkt. 10c.

Carnation Flowered Mixed. Very double and fringed. Pkt. 10c.

Flanders. The scarlet Field Poppy of Europe. Pkt. 10c.

Single Mixed. Pkt. 10c.

PORTULACA (Rose Moss). 6 in. Charming little hardy annual plants, flourishing under almost any conditions, although hot sun and light, sandy soil suit it best. Nothing prettier for edgings, rockwork, beds and undergrowth for tall plants. Seed does not germinate until hot weather, so sow late.

Single Mixed. Each strong plant will cover a space of about $1 \mathrm{ft}$. in diameter. Pkt. 5c.

Double Mixed. Flowers are full and perfect as tiny Roses. This type does not reproduce, so if double plants are desired, fresh seed must be obtained each year. As all seed is very fine, first mix with sand and sow lightly, and do not cover deep. Pkt. 10c.

RICINUS (Castor Oil Plant). Ornamental plants of stately growth and picturesque foliage. Gives a semi-tropical effect to the garden. Tall varieties grow 8 to $10 \mathrm{ft}$. high with leaves several feet across. Make a handsome hedge or screen.

Cambogensis. Dark maroon, stems black. Pkt. 5c.

Sanguineus. Red stems and seeds. Pkt. 5c.

Zanzibarensis. Very large size, immense leaves varying from light green to coppery bronze, with reddish ribs. Pkt. 5c.

RUDBECKIA bicolor superba (Cone Flower). $21 / 2 \mathrm{ft}$. Attractive, compact annual plants for beds or borders or clumps among shrubs. Showy, large yellow flowers with velvety brown central cones. Easily grown, suitable for cutting. Pkt. 10c.

SALPIGLOSSIS (Painted Tongue). $2 \mathrm{ft}$. Showy, half-hardy annuals, bearing beautiful, funnelshaped flowers, with dark veins on white, crimson, yellow and oragne grounds. Very easily grown, requiring light, rich, sandy loam. Bloom from late Summer until frost. If you have never tried this flower, buy a package of seed and you will always have it in your garden.
Grandiflora, Mixed................ Pkt. .10

SALVIA (Flowering Sage) (Scarlet Sage). $21 / 2 \mathrm{ft}$. A bedding plant that will keep the garden bright with color until late in the Fall. Very valuable for pot culture, for cutting and for borders. Sow seed in window boxes or frames in March or April and set plants outdoors in May; or sow outdoors by June 1st and protect from strong winds and heavy rains. Will grow and bloom profusely in any good light rich soil.

Clara Bedman, or Bonfire. A well known, compact form of Salvia, the freest blooming of all; covered with flaming scarlet spikes. Pkt. 10c.

Splendens. A well known bedding plant, with long, flaming flower spikes opening one at a time making a display until frost. Pkt. 10c.

SCABIOSA (Mourning Bride) (Pincushion Flower). $2 \mathrm{ft}$. A favorite garden annual. The beautiful flowers are borne on long, stiff stems and come in exquisite soft shades of many colors. Sow seed out of doors any time after danger of frost is past. They come into bloom in July and continue until frost. Make effective borders or beds. Give plenty of room and keep seed pods cut off.

Finest mixed. Colors from white down through. to Deep Blue and Black. Pkt. 10c.

SCARLET RUNNER BEAN. A great favorite in England and Europe, not only as an ornamental climber, but for its edible beans. Covered with bright, scarlet, pea-shaped flowers. Pkt. 10c.

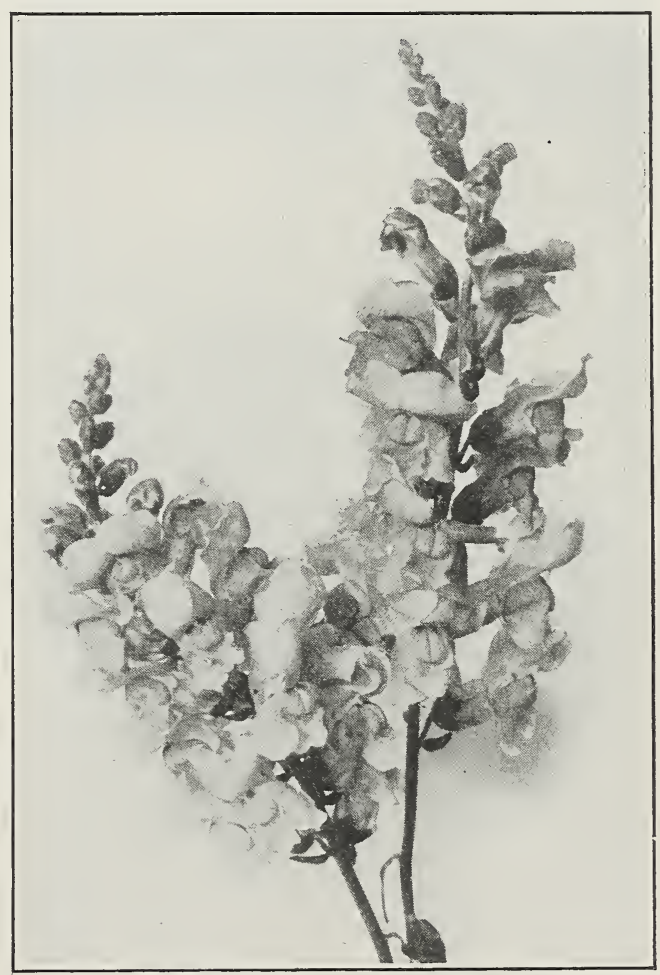

Snapdragon (Antirrhinum)-See page 17 
SCHIZANTHUS (Butterfly, or Fringe Flower). $1 / 2$ to $2 \mathrm{ft}$. Very beautiful and showy annual plants for beds or borders. Covered with a multitude of small, butterfly-like flowers in striking colors. Makes fine pot plants for the house for late Winter and early Spring flowering. For this purpose sow in the Fall.

Wisetonensis. Used largely as a pot plant for the house or conservatory. Free flowering, flowers varying from almost white with yellow eye, to brilliant rose with brown center. For outdoor flowering sow in February. Pkt. 10c.

Mixed Varieties. Pkt. 10c.

STOCKS (Gilly Flower). $1 \mathrm{ft}$. One of the most popular annuals. Unsurpassed for bedding, cutting, edging and pot culture. For early flowers sow under glass in March or April. Transplant seedlings when 1 in. high and transfer to garden in May, setting a foot apart. For later flowers sow outdoors in May. Plants which begin to bloom late may be potted and will bloom all Winter in a room cool and moist.

Ten Weeks Stocks. Light blue, white, canary, dark blue, crimson, Rose and Mixed. Pkt. 10c.

Cut-and-Come-Again, Stocks. Sown in March will bloom in July and continue until frost. Flowers double and very fragrant.

Princess Alice. White

Creole. Creamy-yellow

Sapphire. Dark blue.

La France. Silvery rose..

May Queen. Lilac.

Brilliant. Blood-red

Finest Mixed.

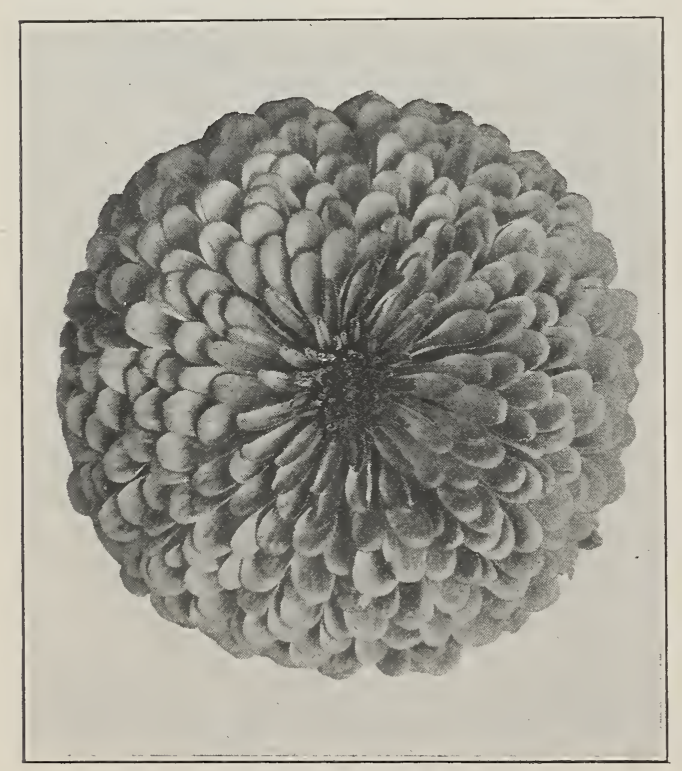

Zinnia-See page 25

\section{SUNFLOWER. (See Helianthus.) QUEEN GITY ORCHID FLOWERING SWEET PEAS}

We offer the following varieties as being the best of their kind. We might extend this list to include a much larger number of varieties without giving you anything better than we can in the above selection. In our "Extra Choice Blend" you will find a great variety of rich colors and an assortment which will please you.

Culture.-Sweet Peas do best in a cool, deep, moist soil and a sunny location. The ground should be deep and rich. Prepare in the Fall if possible, but if done in the Spring use well rotted manure. Bonemeal or sheep manure is excellent if rotted manure cannot be obtained. Sow early as Sweet Peas need the cool, moist Spring ground to make root growth. Sow in deep furrows, at least 6 inches deep. Cover seed 1 inch deep. When plants are 2 inches high thin to 3 to 4 inches apart and fill in with another inch of soil, always leaving a part of the plant above the surface. Continue as plants grow until trench is practically full. Water thoroughly and frequently during dry weather and give an application of liquid manure once a week. Mulch with hay or lawn rakings to hold moisture and keep ground cool. Pick blossoms often to prevent plants running to seed.

Pkt. Oz.

Blue Monarch. Strong blue....... \$0.10 $\$ 0.40$

Constance Hinton. White.......... . 10.40

Hercules, Pink ................... . $10 \quad .40$

King Edward. Scarlet............. . $10 \quad .40$

Florence Nightingale. Lavender..... . $10 \quad .40$

Warrior. Maroon.................. $10 \quad .40$

Primrose. Creamy-yellow . . . . . . . . . $10 \quad .40$

Conquest, Salmon-Pink. . . . . . . . . . 10 .40

Extra Choice Blend Spencer Mixed. . . $10 \quad .40$

Choice Mixed ................. . . . .25

THUNBERGIA (Black-Eyed Susan). $5 \mathrm{ft}$.

Alata, Mixed. Beautiful trailing plants for hanging baskets, lawn vases, also for fences and verandas. Flowers in buff, white, orange, etc., with dark eyes. Prefers a warm, sunny location. A tender, perennial, but grown as an annual. Pkt. 10c.

VERBENA. A pretty annual bedding plant or creeper. In good soil one plant will cover 3 to 4 ft. Splendid for beds, borders, window boxes, etc. For early Spring flowers sow under glass in February. For later flowers sow in March and April. Soak seed for a few hours in luke-warm water and sow in boxes with light, rich soil, covering $1 / 4 \mathrm{in}$. deep. When seddlings are $1 \mathrm{in}$. in height transplant. Set out in May in sunny location. Plants bloom from early Summer until frost.

Pkt.

Lucifer, Intense brilliant scarlet.......\$0.10

Defiance, Scarlet.................. . 10

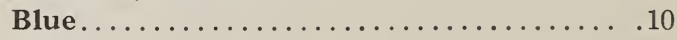

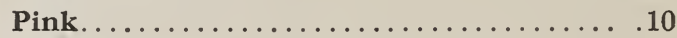

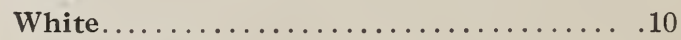

Choice Mixed.................... . 10

VIOLA. (See Pansy.) 
VISGARIA (Rock Lychnis). $1 \mathrm{ft}$. Free blooming annuals closely related to Lychnis. Make compact plants and are covered all Summer and Fall, with bright colored flowers, shaped like single Pinks and borne on long stems. Sow seed where they are to bloom, thinning out so as not to crowd.

Choice Mixed. Pkt. 10c.

WILD GUCUMBER (Echinocystis lobata). A very quick growing annual vine. Splendid for covering trellises, old stumps, fences, etc. Bright green, clean foliage and sprays of white flowers during July and August. Pkt. 5c.

WILD FLOWER GARDEN. A mixture of easily grown annuals for childrens gardens, shrubberies, roadside planting, etc. Pkg. 5c.

ZEA japonica (Rainbow Corn). $5 \mathrm{ft}$. An ornamental foliage plant which is highly effective and interesting. Grows quite bushy, with variegated foliage, bright green, silvery white, rosy-purple and sulphur-yellow. Excellent for mixed border. Pkt. $10 \mathrm{c}$.

ZINNIA (Youth and Old Age). This is an oldtime favorite and one of the most brilliant, satisfactory and showy annuals. Sow the seed early in a hotbed or sunny window and transplant or sow later in the open ground. Come into flower early and bloom until frost.

Salmon.......................\$0.10

Golden Yellow ................... . 10

Scarlet..................... .10

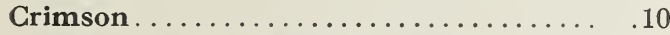

Large Flowering Double Mixed ........ . 10

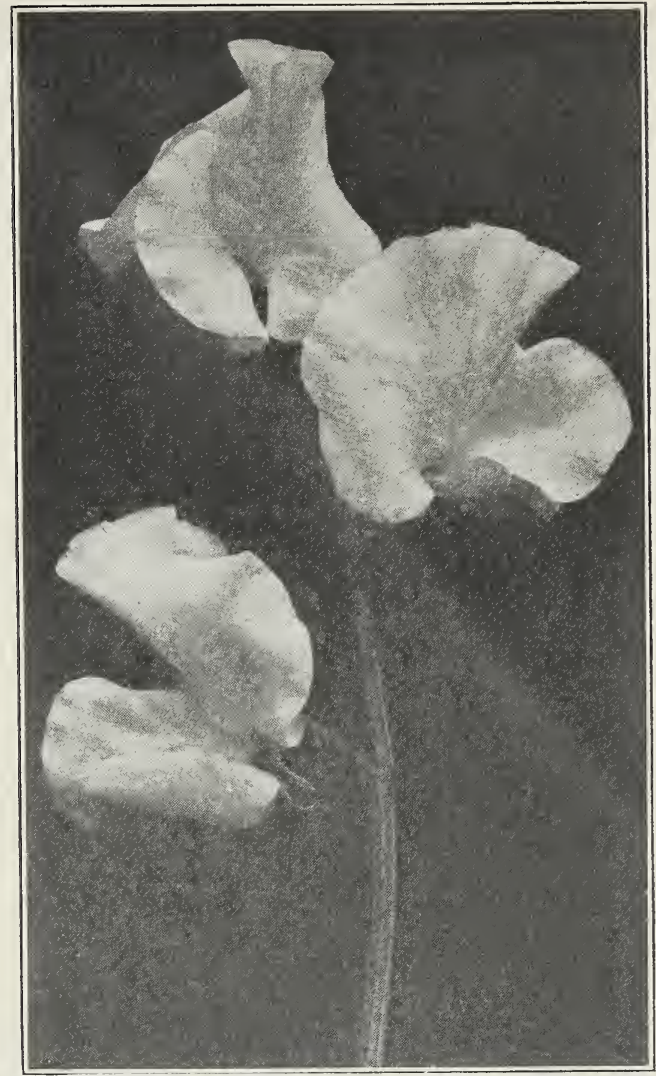

Sweet Peas

\section{BEDDING PLANTS}

During May and early June we have a large assortment of bedding plants such as

ASTERS,

SNAPDRAGONS,

ENGLISH DAISY, GARNATION, COSMOS, MARIGOLD,
MIGNONETTE,

FORGET-ME-NOT,

PANSIES,

PETUNIAS,

ANNUAL PHLOX, SALPIGLOSSIS,
SALVIA,

SCHIZANTHUS, SCABIOSA, STOCKS, VERBENA, ZINṄIAS,

Also Perennial Plants, which see on pages 36,37 and 38 . 


\section{Perennial Seeds}

Perennials are plants that bloom the second year from seed and the plant lives and blooms for many years. If sown in early Spring, many perennials will bloom the first year from seed. The tender and half hardy perennials are best sown in the Spring when danger of frost is past and the hardy varieties sown in the late Summer or very early Fall for next year's flowers. It is a good plan at the beginning of frost to cover lightly with straw, leaves or any dry litter to afford some protection from the extreme Winter cold. Remove as soon as the frost is out of the ground and loosen the surface of the soil around the plants which may be transplanted to the flower garden if they were not set in place in the Fall.

ACHILLEA (Milfoil, or Yarrow).

Ptarmica (The Pearl). $2 \mathrm{ft}$. One of the best white hardy plants. Covered with pure white flowers from sowing to Fall. Easily grown. Pkt. 10c.

ACONITUM (Monk's Hood).

Napellus. $4 \mathrm{ft}$. Does well in shade. Large, dark blue, helmet-shaped flowers in August. Pkt. $10 \mathrm{c}$.

Fischeri. Dwarf variety. 18 inches high. Pale blue flowers. Pkt. 10c.

AL YSSUM (Madwort). Pretty, small plants for vases, bedding, rockwork.

Saxatile compactum. (Basket of Gold). $1 \mathrm{ft}$. Bright yellow flowers. Pkt. 10c.

ANCHUSA (Alkanet).

Italica, Dropmore Variety. 3 to $5 \mathrm{ft}$. Starshaped flowers of rich gentian blue. May and June. Desirable in hardy borders. Pkt. 10c.

ANEMONE (Wind Flower).

Coronaria, Mixed (Poppy Anemone). Poppyshaped flowers, brilliant and showy. Fine for bouquets. Sow in Spring, and keep shaded until plants appear. Pkt. 10c.

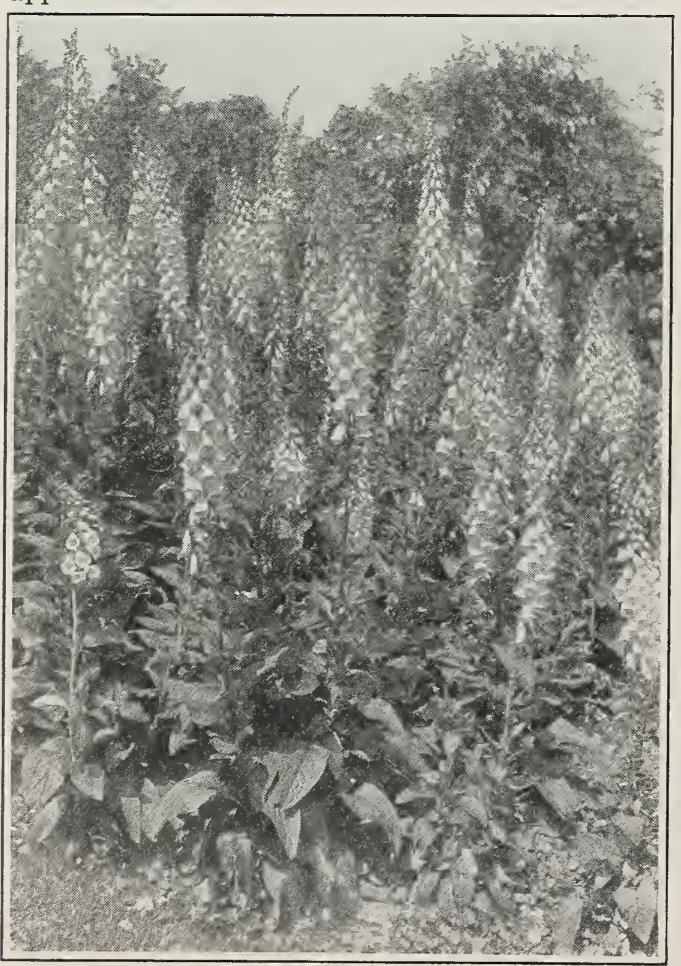

Foxglove
AQUILEGIA (Columbine). Sown in open ground early in Spring, will bloom first year, or planted in August or September will make vigorous plants, blooming is early Spring. Very graceful, generous blooms and well adapted for cut flowers.

Hybrid-Long-Spurred, MixedColors. Pkt.10c. ARABIS (Rock Cress).

Alpina. 6 inch. One of the earliest and prettiest white Spring flowers. Splendid for rockery or edging. Withstands drought. Pkt. 10c.

BELLIS perennis (English Daisy). Stands Winter if given light protection. Sow seed in August. Will bloom well into Summer.

Double Mixed. 6 in. Pkt. 10c.

BOCCONIA (Plume Poppy, or Tree Celandine). Effective for single specimens or in groups. $5 \mathrm{ft}$.

Cordata. Foliage green, spikes of cream-colored. Poppy-like flowers, 2 to $3 \mathrm{ft}$. long. Pkt. 10c.

BOLTONIA asteroides (False Chamomile). Similar to hardy Asters. $6 \mathrm{ft}$. tall. Pure white flowers like Michaelmas Daisies, bloom September and October. Pkt. 10c.

CAMPANULA (Canterbury Bells). Sow seeds in May or early June in fine soil. Transplant by August 1st to place where they are to bloom or transplant temporarily and put in permanent place by October 1st. When ground freezes cover lightly with straw or coarse hay.

Medium (Single Canterbury Bells). Beautiful bell-shaped blossoms. Pkt. 10c.

Double Mixed. Pkt. 10c.

Calycanthema (Cup and Saucer). This is the finest type of this old-fashioned and much prized garden flower. May be grown in pots for indoor decoration. White, blue, pink, lavender, and mixed. Pkt. 10c.

COREOPSIS lanceolata grandiflora. 2 to $3 \mathrm{ft}$. A very popular hardy plant. Flowers rich golden yellow, like a yellow Cosmos. Good for cutting. Blooms late in June and continues the entire Summer and Fall. Pkt. 10c.

CANDYTUFT (Hardy).

Iberis sempervirens. $1 \mathrm{ft}$. Low growing, foliage evergreen. Pure white flowers in Spring and early Summer. Much used for cemeteries and rockeries. Pkt. 10c.

Gibraltarica. Lilac flowers. Pkt. 10c.

GARNATION (Hardy Garden Pink).

Plumarius (Grass Pink, Scotch Pink, Pheasant Eye Pink). A beautiful, single hardy pink, flowers fringed and different colors. Pkt. 10c.

CHR YSANTHEMUM (Hardy Varieties).

King Edward VII. Large white flower sometimes called Moonpenny Daisy. Pkt. 10c.

Japonicum fl. pl., Double Mixed. Pkt. 10c.

DAISY, English. (See Bellis perennis).

DAISY, Shasta. $11 / 2$ to $2 \mathrm{ft}$. Large, showy flowers of glistening white, with golden centers. Splendid for borders. Pkt. 10c. 
DELPHINIUM (Hardy Larkspur). 5 to $6 \mathrm{ft}$ One of the most exquisite flowers we have. Very effective in beds or masses, in borders, in combination with the hardy Madonna Lillies. Sow in the Fall or very early Spring. Sown indoors in Spring and transplanted to the open as soon as weather permits should bloom in July or August. Sown outdoors in Spring will probably not bloom until following year.

Belladonna. Clear, turquoise-blue. Pkt. 10c.

Bellamosum, Rich, deep blue. Pkt. 10c.

Formosum. Rich dark blue with white center. Pkt. 10c.

Chinese alba grandiflora. White. Pkt. 10c.

Gold Medal Hybrids, Mixed. Colors from pearl white through to lavender and dark blue. Pkt. 10c.

DIGITALIS (Fox Glove). $3 \mathrm{ft}$. Highly ornamental and handsome hardy plants. Succeed with but little attention and give profusion of bloom during June and July. Excellent for naturalizing among shrubbery, the edge of woods, and other half shady places.

Gloxiniaeflora. Handsome, spotted, Gloxinialike flowers on long stems. Pkt. 10c.

GAILLARDIA (Blanket Flower). $2 \mathrm{ft}$. Among the showiest and most effective hardy perennial plants. Should be in every hardy border. Require little or no protection and take care of themselves. Flowers large, yellow and crimson, and shaped like a large Daisy. Fine for cutting.

Grandiflora, Mixed. Newest hybrids. Pkt. 10c.

GRASSES, ORNAMENTAL.

Erianthus (Pampas Grass). Grows 10 to $12 \mathrm{ft}$. high with sometimes 30 to 50 plumes. Pkt. 10c.

Eulalia japonica zebrina (Zebra Grass). 6 to $7 \mathrm{ft}$. A grass with long blades marked with broad yellow bands across the leaf. Attractive as specimen plants for the lawn. Pkt. 10c.

Pennicetum longistylum. Graceful, greenishwhite plumes. Excellent for beds. $2 \mathrm{ft}$. Pkt. 10c.

Pennicetum Rueppelianum (Purple Fountain Grass). Graceful green foliage and purple plumes. Fine for an edging for a bed of tall plants such as Cannas. Pkt. 10c.

Uniola la tifolia (Spike Grass). A native variety with pretty, graceful drooping panicles. Pkt. 10c.

GYPSOPHILA paniculata. $2 \mathrm{ft}$. White flowers, fine for bouquets. A favorite hardy perennial. Blooms first year from seed if sown early. Thrives in any good garden. Pkt. 10c.

HELENIUM (Sneezewort).

Autumnale superbum. A hardy perennial, growing well in almost any soil. Covered with heavy bloom of golden yellow flowers in late Summer. 5 to $6 \mathrm{ft}$. Pkt. $10 \mathrm{c}$.

Riverton Gem. Yellow, changing to red. $5 \mathrm{ft}$. Pkt. 10c.

Riverton Beauty (Hardy Black EyedSusan). Rich lemon-yellow with purple black cone.

HELIANTHUS (Perennial Sunflower).

Mixed Hybrids. Consists of the finest single flowering, hardy perennial sorts. Sown early will make flowering plants the first year. Pkt. $15 \mathrm{c}$.

HOLLYHOCK. 6 to $8 \mathrm{ft}$. Makes a beautiful showing in the hardy garden. As a background to hide a building or fence they are unsurpassed. The double and the single fringed are very fine and brilliantly colored. Seed sown by mid-Summer will produce flowering plants the following season.

Alleghany, Double Mixed. Very large flowers in colors from pale pink to deep red. Pkt. 10c.

Double White. Pkt. 10c.

Double Pink. Pkt. 10c.

Single Mixed Pkt. 10c.

HONESTY (Moonwort) (Satin Flower). $2 \mathrm{ft}$. A plant grown for its curious seed pouches, which are of a beautiful silvery appearance and used for house ornaments. Pkt. 10c.

LAVENDER Vera. Well known sweet scented, perennials. Fine in the mixed border. $3 \mathrm{ft}$. Pkg. 10c.

LATHYRUS. (See Peas.)

LOBELIA (Cardinal Flower).

Cardinalis. 1 to $2 \mathrm{ft}$. Rich, fiery cardinal flowers. Prefers a moist location. A fine, hardy border plant. Pkt. 10c.

LYCHNIS chalcedonica (Rose Campion), (Maltese Cross), (Scarlet Lightning), (Jerusalem Cross). 2 to $3 \mathrm{ft}$. Scarlet, single flowers, useful for massing in beds or borders. Will bloom the first season if sown early. Pkt. 10c.

Haageeana. Brilliant orange, scarlet, crimson, etc., in mixture. $1 \mathrm{ft}$. high. Pkt. 10c.

LUPINUS (Lupin).

polyphyllus. $3 \mathrm{ft}$. Blooms in May and June. Free flowering. Long, graceful spikes of Peashaped flowers, valuable in mixed borders and in beds for cutting. Prefers a little shade.

Mixed Colors. Pink, white, blue. Pkt. 10c.

LYTHRUM (Loose-strife).

Roseum Superbum. $3 \mathrm{ft}$. high. Spikes of rosy flowers. July to September. Pkt. 10c.

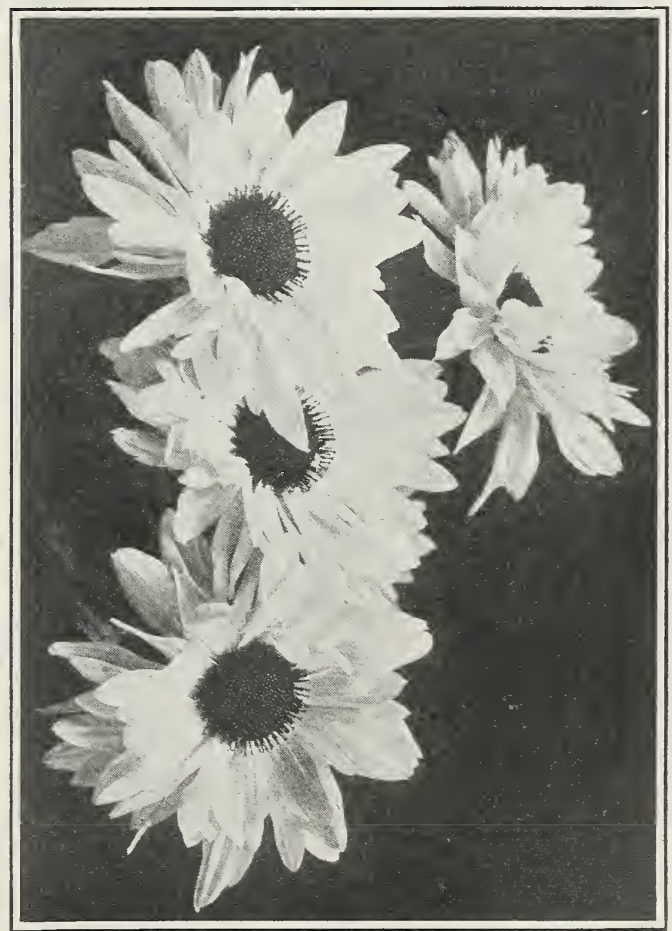

Shasta Daisy 
MYOSOTIS. Palustris semperflorens. Hardy Forget-me-not. Similar to the annual varieties but hardy. Fine border plant. Pkt. 10c.

PENTSTEMON (Beard Tongue). $3 \mathrm{ft}$. Highly useful and attractive perennial. Blooms from June until frost the first year if sown early. Pendant, bell-shaped flowers. Shaded and marked with scarlet, white and pink. Not quite hardy and best treated like Verbenas, Salvia, etc. Pkt. 10c.

PEAS (Hardy Sweet) (Lathyrus). Useful for covering walls, trellis, etc. Plants will live for years. Continually in bloom. Fine for cutting.

Mixed Colors. Pkt. 10c.

PHLOX, HARDY (P. decussata). Fine selection. Sow early in Fall. A very desirable addition to the hardy border. Mixed Colors. Pkt. 10c.

PHYSALIS Franchetii (Chinese Lantern Plant). Very ornamental. About $2 \mathrm{ft}$. high with bright, orange scarlet, lantern-like fruit. Pkt. 10c.

PLATYCODON (Balloon Flower) (Japanese Bell-flower). Very showy flowers throughout the entire season. Forms large clumps. Excellent for the hardy border or among shrubs. Flowers violet blue, steel blue and white. Pkt. 10c.

POPPY, HARDY.

Oriental, Mixed Hybrids. 21/2 ft. Sow seeds in early Spring. The plants disappear in mid-Summer and re-appear in Fall when they should be transplanted to permanent quarters. Large, cupshaped blossoms. Very showy and brilliant. Pkt. 10c.

Mixed, Pkt. 10c. Scarlet, Pkt. 10c

Iceland (Papaver nudicaule). $1 \mathrm{ft}$. Graceful, bright green foliage, with slender flower stalks. Brilliant flowers in profusion useful for cutting if picked in bud. Pick off seed pods and they will continue in bloom the entire season.

Finest Mixed Colors. Scarlet, white, orange, etc. Pkt. $10 \mathrm{c}$.

PYRETHRUM. Attractive hardy plants useful in borders.

hybridum (Finest Mixed Single). Large Daisy or Cosmos-like flowers in colors from white to pink and deep red with yellow centers. Bloom May and June, and again in Fall. A most graceful and long lasting cut flower. Pkt. 10c.
RUDBECKIA (Cone Flower). $3 \mathrm{ft}$.

purpurea. A most interesting hardy perennial with large, reddish-purple flowers, 4 in. across. Pkt. 10c.

laciniatus (Golden Glow). Pkt. 10c.

SALVIA azurea grandiflora. Blue perennial. A fine, showy plant with silvery-gray foliage and sky-blue, Salvia-like blossoms. $3 \mathrm{ft}$. July and August. Pkt. 10c.

SCABIOSA (Pincushion Flower). $21 / 2 \mathrm{ft}$.

japonica. From Japan. Lavender blue flowers on long, wiry stems. Fine for cutting. Pkt. 10c. SHASTA DAISY. (See Daisy).

STATICE (Sea Lavender). $1 \mathrm{ft}$. A beautiful, everlasting flower. Pretty plants for rockwork and in the Summer garden, in beds or borders. Flowers small and numerous and are dried for everlastings.

latifolia. Purplish-blue flowers. Pkt. 10c.

SWEET WILLIAM (Dianthus barbatus). A sturdy old-fashioned flower. Beautiful, fragrant and worthy of a place in every hardy border. Seed may be sown at any time from Spring to mid-Summer, as young plants bloom most freely. It is well to sow each year. Mixed Single. Pkt. 10c.

Mixed Double. Pkt. 10c.

latifolius atrococinneus fl. pl. (Everblooming Sweet William). A brilliant, crimson-scarlet variety and very effective wherever placed. Pkt. 10c.

VERBENA. $1 \mathrm{ft}$.

venosa (Hardy Garden Verbena). Much used for bedding purposes. Flowers from early Summer until late Fall. Bright purplish-heliotrope flowers. Pkt. 10c.

STOKESIA (Corn Flower Aster). $2 \mathrm{ft}$. A rare and beautiful hardy perennial plant bearing a large number of lavender-blue Bachelor Button-like flowers of large size. In bloom from July until frost. Splendid for the hardy border and for cutting. Pkt. 10c.

WALLFLOWER. Fragrant, half-hardy perennials blooming early in the Spring, with spikes of beautiful flowers. Protect in coldframe during Winter and plant out in April or early May.

Double Mixed. Pkt. 10c.

\section{Field and Farm Seeds}

Prices are all subject to market changes. Write or inquire for prices. Sacks extra.

TIMOTHY. The best and by far most important of all hay grasses. Produces a large crop of hay on moist loamy or clayey land. Not so well suited for light, sandy soils. Stands drought and extreme heat and cold. If sown alone use at least 25 pounds per acre; with Red Top and Red Clover, 15 pounds Timothy, 12 pounds Red Top and 2 pounds Red Clover; with Red Clover only, 20 pounds Timothy, 5 pounds Clover. Timothy weighs 45 pounds per bushel.

RED CLOVER, MEDIUM. One of the most valuable farm crops for pasture, hay or for turning under for green manure. Sow in Spring; 15 pounds to the acre. Clover weighs 60 pounds to the bushel.

RED or CRIMSON CLOVER. Mammoth. Should be included in all permanent pasture mixtures. Sow 10 to 14 lbs. per acre.

ALSIKE. A perennial 1 to $3 \mathrm{ft}$. high, succeeding best in cold, stiff soils and in marshy lands too wet for other varieties. A good honey plant for bees. Sow 8 pounds to the acre. Alsike weighs 60 pounds per bushel.

ALFALFA. Requires a deep, rich well drained soil as the tap root is very long, descending sometimes 10 to 15 feet. Sown at about the same time as Oats, in thoroughly prepared, deeply plowed soil at 20 to 25 pounds per acre. Cut when plant is in bloom. In suitable soil, it is a perennial and several crops may be cut each year. Alfalfa weighs 60 pounds per bushel.

WHITE CLOVER, CHOICE. A dwarf variety, spreading rapidly and very hardy. Valuable in permanent pastures as it stays green throughout the year. Sow in Spring 8 to 10 pounds per acre.

SWEET GLOVER, White Blossom. Improves the soil. Stands summer heat and winter cold. Has high feeding value. Sow in Spring or Fall, $20 \mathrm{lbs}$. per acre. Weighs 60 lbs. per bushel.

ORCHARD GRASS. Very hardy and productive and makes excellent hay. Stock of all kinds are very fond of it. Will stand considerable shade. Not suitable for lawns. Sow about 50 pounds per acre. Weighs 14 pounds per bushel. 
RED TOP, or HERD'S GRASS, SOLID SEED. A very hardy, perennial grass, succeeding best on moist land. It may be sown on dry lands and stands hot weather admirably. Remains green the greater part of the year. The trailing stems make a close, matted turf. Sow 12 to 16 pounds per acre. Red Top weighs 32 pounds per bushel.

BLUE GRASS, KENTUGKY. A very valuable pasture grass, very productive and nutritious. A true perennial lasting indefinitely and improving each year. Succeeds in almost any soil and stands long continued dry weather and hot sun. As it takes several years to get established it should be sown with other grasses. Sow 50 pounds per acre for pasture. Weighs 14 pounds per bushel.

BLUE GRASS, CANADIAN. A hardy perennial grass with creeping root stalks. Grows on poorest and dryest soils, sandy, gravelly or clayey, stands extremes of wet or dry and keeps green very late. Valuable for pastures. Sow 50 pounds per acre. Weighs 14 pounds per bushel.

RYE GRASS, FANCY ENGLISH. A carefully selected, dwarf growing variety, especially fine for lawns. Will make a fine turf in three weeks. Weighs 24 pounds per bushel. Sow 40 to 50 pounds per acre.

\section{MILLET}

(Weighs 50 pounds per bushel.)

JAPANESE. Especially valuable for planting on low lands. 10 to 15 pounds per acre.

HUNGARIAN. Produces a crop quickly and can therefore be planted later than the other sorts. $1 / 2$ to 1 bushel per acre.

GOLDEN. Extra large seed heads. Sow $1 / 2$ to 1 bushel to the acre.

\section{FIELD CORN}

Northern Grown Seed. 8 to 10 quarts per acre in hills for ears; 2 to 3 bushels per acre for fodder.

Pride of the North. Ears 8 to 10 inches long. Kernels closely set. Cob small and red; stalk medium, height 6 to 8 feet.

Leaming Improved. Similar in shape and size to Pride of the North. A fine ensilage Corn.

Eureka. A fine white Dent Corn, especially adapted for growing in this section. Ears 8 to 10 inches long and evenly filled out, maturing in about 100 days.

Genesee Valley Flint. A small nearly round kernel, deep yellow and very hard. Ears good size and well filled out. An early, quick growing variety, maturing in about 90 days.
Sanford Flint. One of the finest white flints grown. Very productive, medium size ear averaging 10 inches in length. Handsome, large, well filled grains.

Excelsior. A very early yellow Dent Corn. Large ears. Gives excellent satisfaction; a 90-day Corn. Seed grown in Pennsylvania and acclimated to eastern conditions.

\section{SEED GRAINS}

BARLEY, Six-rowed. Sow 2 bushels per acre. SPRING WHEAT, Marquis. Sow $1 \frac{1}{2}$ bushels per acre.

SPRING RYE. Weighs 56 pounds per bushel. Sow 1 to $1 \frac{1}{2}$ bushels per acre.

BUCKWHEAT. Weighs 48 pounds per bushel. Sow 2 bushels per acre.

\section{Recleaned Silver Hulled.}

Japanese.

COW PEAS. One of the largest yielding and most nutritious forage crops grown. Also improving the productiveness of the soil. Sow when ground is warm. Cow Peas fed either green or as hay, have a very high feeding value; $1 \frac{1}{4}$ to $11 / 2$ bushels per acre.

SOY BEANS. A native of the South as are Cow Peas, and considered by many their equal in value for pasturing or plowing under. Plant when the ground is warm and drill in at the rate of $3 / 4$ to 1 bushel per acre.

CANADA FIELD PEAS. Grown with Oats makes a hay or fodder which will double the production of milk. Sow early 2 bushels Peas and 1 bushel of Oats and harrow in. Cut when the Oats are in of Oats to the acre. Sow Peas and plow under and then sow the milk and pods formed in the Peas. Weighs 60pounds per bushel.

DWARF ESSEX RAPE. One of the best crops for sheep or hog pasturage. Ready to use in six to eight weeks. One acre will feed a dozen sheep for two months. Plant from April to August, 3 pounds per acre drilled in, or 5 pounds when broadcast. Weighs 50 pounds per bushel.

Spring Vetch. Used for soiling or fodder. Sow about 90 pounds to the acre, when alone or with Wheat or Oats about 50 pounds.

\section{OATS}

Oats. Excelsior Seed Oats. Heavy and full of life. Big yields of large well-filled heads. Sow $21 / 2$ bu. per acre.

\section{The Improved Soil Inoculator}

Contains introgin that draws nitrogen from the air and converts it into available plant food in the form of beads or nodules

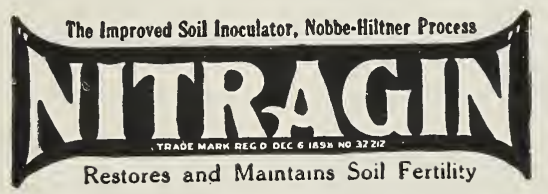

$$
\begin{gathered}
\text { Restores and Maintains Soil Fertility. } \\
\text { For Peas, Sweet Peas, } \\
\text { and Beans }
\end{gathered}
$$

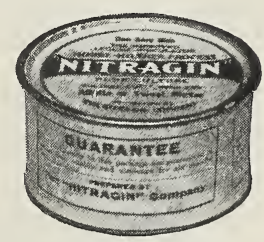

Garden size 20c per tube 


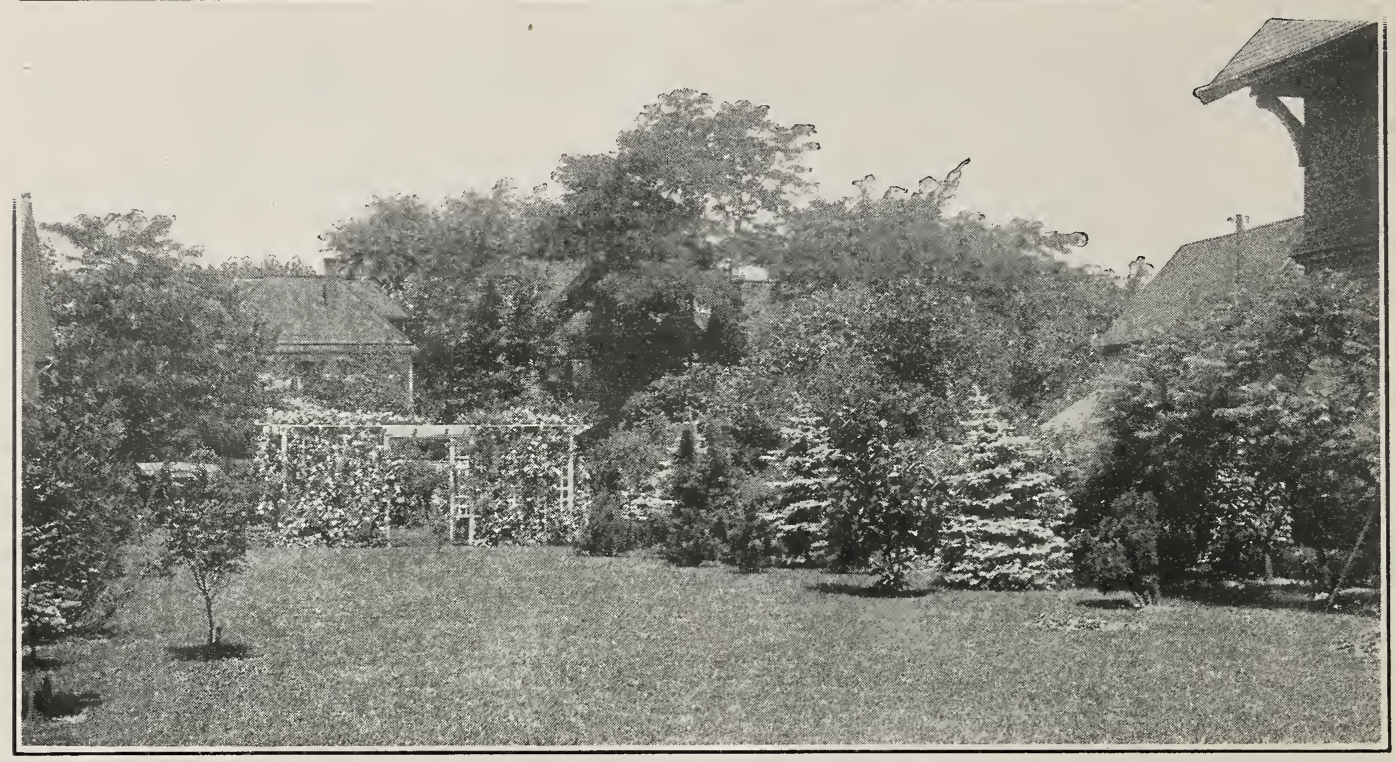

\section{Queen City Seed and Nursery Co.'s Lawn Seed Mixtures}

How to Make a Lawn. The soil should be rich and carefully prepared by spading and raking to make it fine and free from all large stones, roots, and hardened lumps of soil that cannot be readily broken. You cannot expect to get a good lawn on the soil that came from digging the cellar. If you are building a new home make the contractors save the top soil. If this is not suitable procure enough good soil to make the top surface at least a foot deep. This is the only way to get a thick, velvety lawn that will look well even in a dry season. At the final raking before sowing seed, add 1 pound of Sheep Manure to each 10 square feet of surface and then sow Lawn Mixture at the rate of 1 pound to 300 square feet of lawn. Rake again and roll to firm ground. When grass is four inches high cut with mower and thereafter every week or 10 days.

Renovating Lawns. You will find it will pay to re-seed your lawn lightly each year. As early as possible rake off all dead leaves and other litter, and give it a top dressing of Sheep Manure or Bone Meal at the rate of 1 pound to 25 square feet of lawn and rake it in. Then sow about 1 pound of Lawn Mixture to 500 square feet of surface and roll thoroughly. A later dressing of Sheep Manure is beneficial should the lawn show signs of becoming rusty during the Summer.

\section{SUPERIOR LAWN MIXTURE}

A splendid mixture of fine low growing grasses such as Kentucky Blue, Canadian Blue, Red Top, White Dutch Clover, Sheep Fiscue, etc., combined in such proportions as our experience has shown to make a fine close velvety lawn.

Price: $1 / 2$ lb., 20c., 1 lb., 40c., 5 lbs., $\$ 1.75,10$ lbs., $\$ 3.25,20$ lbs., $\$ 6.00$.

\section{SHADY NOOK LAWN MIXTURE}

On many lawns there are spots shaded by trees or spaces between houses where it is difficult to get a good green smooth surface. Frequently the soil in such places is sour and covered with moss and sorrel. These growths should first be removed with a sharp-toothed rake. Then give the ground a liberal coating of Agricultural Lime or Wood Ashes, or both. Spade this thoroughly into the surface soil and then sow Shady Nook Lawn Mixture, at the rate of 1 pound for each 250 to 300 square feet of new lawn. For old lawns add Lime and Wood Ashes as advised above, and sow proportionately less of seed, according to conditions and roll thoroughly.

Price: 1/2 1b., 25c., 1 lb., 45c., 5 lbs., \$2.00, 10 lbs., $\$ 3.75,20$ 1bs., $\$ 7.00$.

\section{QUEEN CITY “SPEGIAL" LAWN MIXTURE}

A well balanced mixture of English and native grasses of quick growing habits that will give you a nice green covering in a few days and form a good thick turf the first season. Per qt. 25c., 4 qts. 75c., pk. $\$ 1.25$, bu. $\$ 5.00$.

\section{GITY PARK LAWN MIXTURE}

A good mixture of various grasses, well proportioned. Will give a good green lawn of rich texture.

Price: 1 1b., 25c., 5 lbs., \$1.15, 10 lbs., \$2.20, 20 lbs., \$4.25.

Putting Green, or Golf Mixture. Lb., 65 cents.

Terrace Mixture. Lb., 45 cents. 


\section{Summer Flowering Bulbs}

\section{FOR SPRING PLANTING}

Bulbs are very easy to grow, are inexpensive, and give a variety of bloom that is unsurpassed in variety of color and time of blooming. As a rule they are planted out of doors soon after the weather becomes warm and settled. Dig after the first frost, when the leaves have turned yellow, and store in some dry place where they will not freeze.

For best results beds should be deeply spaded and a liberal amount of well rotted manure worked in.

\section{AMAR YLLIS}

For pot culture. They require a well drained, turfy, sandy soil and a growing and resting season. Start in moderate temperature and when leaves appear water carefully, and not in too great a quantity. After blossoming and at the approach of Fall, gradually withdraw water and allow bulb to ripen off. Protect from frost.

Florida Hybrids. Enormous individual flowers ranging from deep crimson, orange scarlet to lightrose, striped and variegated. Price $50 c, 75 c, 1.00$.

\section{GALADIUM ESGULENTUM}

\section{Elephant's Ear.}

A vigorous plant with large hanging leaves on long, stiff stems. Most effective either singly on lawns or in centers of beds, or as a background for other lower growing plants. Also planted in groups or as a border for Cannas. Grows to large size in rich soil and an abundance of moisture.

First size Bulbs 10c. each; large size 15c. each; Mammoth 25c. each.

\section{GANNAS}

Give fine results under almost any condition of soil and climate. For best results, however, they should have a sunny location and a generous amount of well decayed manure should be spaded into the bed and water supplied freely. Start plants indoors in pots and set out when ground is warm.

All varieties, except as noted, 10c. each,

\section{$\$ 1.00$ per doz.}

King Humbert. Red. Large flowers, orangescarlet in color, measuring 6 inches across; rich coppery and bronze foliage, broad and massive; 4 to 5 feet high.

King Humbert. Yellow. (Queen Helene). Same as King Humbert Red in habit of growth and flowering, with yellow flowers dotted with red and green foliage. Some plants occasionally give a scarlet or scarlet striped flower.

Florence Vaughan. Bright rich golden yellow spotted with red. Grows to large size and perfect form. Green foliage; 4 feet.

Mrs. A Conard. Has large shaded salmon-pink flowers in abundance. Splendid for planting singly or in beds. Foliage green; 5 feet. $15 \mathrm{c}$ each.

Pennsylvania. Flowers an intense vermilion scarlet overlaid with an orange sheen. Flowers. produced freely. Foliage a rich green; 5 feet.

Shenandoah. Flowers are salmon-pink borne in large clusters. Foliage rich ruby red. $4 \mathrm{ft}$.

Wyoming. True orchid-flowered variety, with magnificent orange-colored flowers. Foliage purple. 5 feet.

\section{DAHLIAS}

One of the most showy Autumn flowers. A sandy soil, well enriched, and a sunny location is preferred, yet good results may be obtained on almost any soil. Plant about 3 feet apart. Large clumps of roots should be divided, leaving one or two eyes to the tuber. Plant tuber flat on side, about 6 inches deep. Cultivate until blooming period. Take up tubers after hard frost, allow to dry off and store in sand or dry earth in a cool, dry place, safe from frost. Do not plant out until ground is warm.

Decorative. Crimson, White, Yellow, Pink, Purple and Mixed.

Ball. Red, Pink, Yellow, White, Purple and Mixed.

Cactus. Red, White, Pink, Yellow, Purple and Mixed.

Mixed colors $10 \mathrm{c}$ each.

Separate colors $15 \mathrm{c}$ each.

\section{GLADIOLUS}

Everyone should grow these easily cared for and most satisfactory bulbs. Plant some early and follow every 10 days for succession of bloom. Set 2 to 6 inches deep, according to size and about 6 inches apart. Cut flower spike when first blossom unfolds. Place in winter and the buds will open well and last for several days if water is changed daily

\section{Prices subject to change.}

America. Soft flesh pink, tinged with lavender. Doz. 50c., 100, $\$ 3.50$.

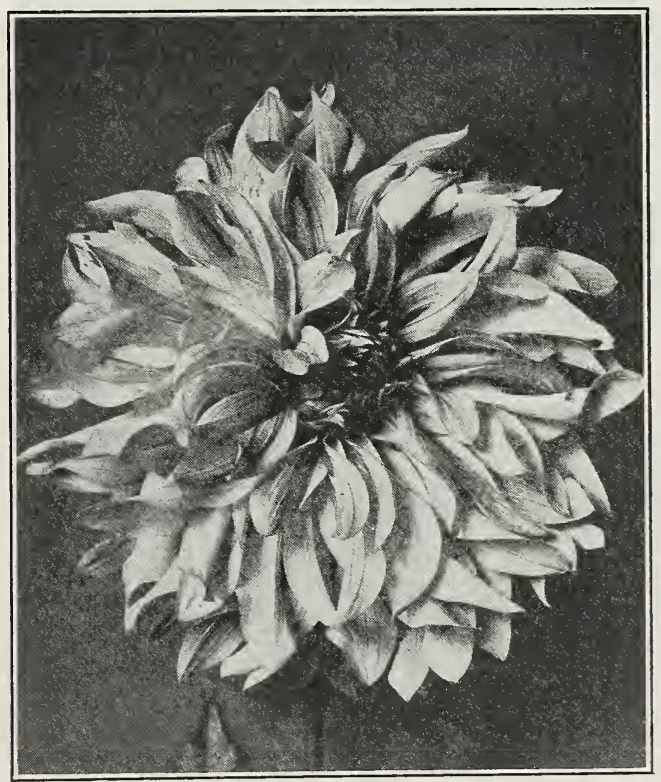

Cactus Dahlia 
Ali. Fine lavendar blue inside, slightly darker outside. Strong stem and flowers of good size. A very attractive blue. Doz., $\$ 1.00 ; 100, \$ 7.50$.

Baront Hulot. A deep blue of an indigo shade Smaller flowers than some other varieties but very effective. Doz., $\$ 1.00,100, \$ 7.50$.

Chris. Dark maroon-red, with purple shades. Fine for contrast with lighter shades. Doz.,85c., 100, $\$ 6.50$.

Conspicuous. A splendid light blue. Has a darker blue spot with yellow center. Very beautiful. Doz., 85c; $100, \$ 6.50$.

Glory. A deep old rose shade. One of the newer varieties and well worth growing. Doz. $\$ 1.00 ; 100$ for $\$ 7.50$.

Halley. Large flowers of a delicate Salmon-pink, very early. Doz. 60 c., $100, \$ 4.50$.

La Grandesse. Fine large flower, white, slightly tinting into light pink. Doz. 70c.; 100 for $\$ 5.00$

Loveliness. Cream color. Many flowers open at same time. Very showy spike.

Doz., $\$ 1.00,100, \$ 7.50$.

Marchall Foch. A beautiful salmon pink, with spotted red throat. Doz. $\$ 1.00 ; 100$ for $\$ 7.00$.

Mrs. Frank Pendleton. Large size flowers of a salmon-pink color with deep carmine blotches in the throat. Very rich and effective. Doz. 90c., 100, $\$ 6.50$.

Mrs. Francis King. Large flowers, light scarlet or flame color, very effective. Doz., 50 c., 100, $\$ 3.50$.

Niagara. A delightful cream shade, blending to a canary-yellow, splashed with carmine. Doz., $\$ 1.00$, $100, \$ 7.00$.

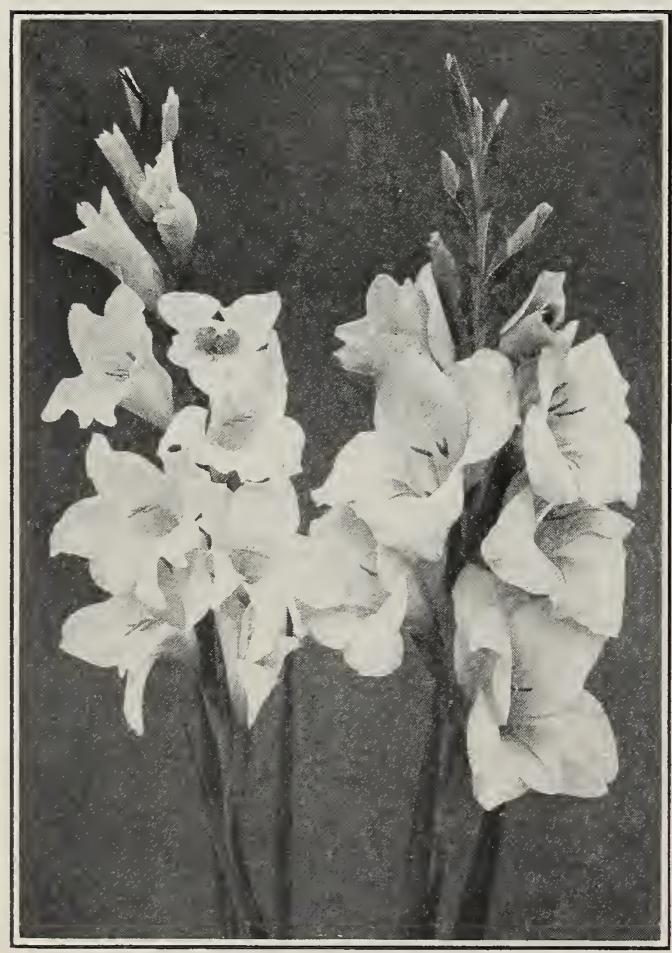

Gladiolus
Odin. Exquisite deep salmon-rose, with broad red spear on lower petals. Shaped like "Holley" and equally early. Doz., $\$ 1.00 ; 100, \$ 7.50$.

Panama. A deep pink or rose color. Best of all pink sorts. Doz. 85c., 100, $\$ 6.50$.

Peace. Immense pure white flowers with a touch of lilac on lower petals. Doz. 75c., 100, $\$ 5.50$.

Pink Perfection. Soft, rosy pink with white stripe in center of each petal. Doz., \$1.00, 100, $\$ 7.50$.

Primulinus Hybrids, Mixed. Flowers of good size borne profusely in all shades of yellow, orange, buff, copper and variegated with these colors. Growth vigorous. Most graceful and beautiful for vases. Doz. 50c., 100, $\$ 3.50$.

Prince of Wales. Delicate salmon rose; aflower of great merit. An early flowering sort. Doz. $\$ 1.00$, 100, $\$ 7.00$.

Red Canna. Similar to Mrs. Francis King but brighter and taller. An excellent cut flower variety. A beautiful scarlet. Doz. $\$ 1.00,100, \$ 7.50$.

Schwaben. A clear canary-yellow with a small blotch of deep garnet in the throat. Doz. 85c., 100, $\$ 6.50$.

War. Dark blood red shaded with crimson-black. The leading red flower. Doz. 85c., 100, $\$ 6.50$.

Wilbrink. This is a sport of Halley but colored similar to America, a soft flesh pink. Doz. 70c; 100 for $\$ 5.00$.

Mixed Gladioli. A splendid mixture of good sorts, including hybrids, which will give you a rare and beautiful assortment of colors. Many fine varieties are included in this mixture. Doz. 35c. $\$ 2.50$ per 100 .

\section{HARDY GARDEN LILIES}

Auratum (Golden Banded Lily of Japan). This beautiful Lily has flowers 6 to 8 inches in diameter, composed of six white petals with chocolate-crimson spots and a broad, golden band in center of each petal. Very fragrant. Suitable for pots indoors. Each, 30c., doz., \$3.00.

Speciosum alba. Grows about $4 \mathrm{ft}$. tall; fragrant, glistening white flowers. Suitable also for pot culture. Each, 30c., doz. $\$ 3.00$.

Regale (Myriophyllum). A rare lily from Japan. Very hardy. White, shading to yellow with pink tinge on outer petals. Each $\$ 1.00$, doz., $\$ 10.00$.

Speciosum rubrum. White, heavily spotted with rich, rosy-crimson spots. Grows 3 to $4 \mathrm{ft}$. tall. One of the most popular garden varieties. Blooms in August. Each, 30c., doz., \$3.00.

candidum (Madonna, St. Joseph's, Annunciation Lily). For Fall planting. Ready in late August. One of the finest and hardiest outdoor white Lilies. Very fragrant. Especially fine when planted with Delphinium. Multiplies freely. Each, 25c.

tigrinum (Single Tiger Lily). Flowers orangered, spotted black. Very hardy and multiplies freely. Each, 15c.

LILY OF THE VALLEY. Well known and popular Spring flowering plant, flowers bell-shaped, white and fragrant. Prefers a partly shaded rather moist location. A few clumps will start a bed and will require but little care. Clumps, each, 25 c. 


\section{Miscellaneous Bulbs and Roots}

DOUBLE PEARL TUBEROSES. One of the most delightfully fragrant and beautiful of the Summer flowering bulbs. Start indoors in pots for early bloom. Plant out of doors when ground is warm. Successive plantings out of doors may be made for late blooms. Not hardy; must be treated same as Gladioli. Each, 10c., doz., \$1.00.

HYACINTHUS candicans (Summer Hyacinths). Planted among shrubbery, or with scarlet Geraniums. They produce a beautiful effect in August and September, with their Fall flower-spikes 3 to $4 \mathrm{ft}$. high, with 20 to 30 white, bell-shaped blossoms. Not hardy. Each 10c., doz. $\$ 1.00$.

MADEIRA VINE (Climbing Mignonette). A tuberose-rooted, rapid-growing climber. Fine for trellis or screened porch or veranda. Fleshy, heartshaped leaves and hanging stems of fragrant white flowers. Each, 10c., doz. $\$ 1.00$.

CINNAMON VINE (Chinese Potato or Yam). Very tall climber with deep roots. A tropical plant but hardy here. Glossy heart-shaped leaves and sweet scented flowers. Each 10c.

\section{BEGONIAS - TUBEROUS ROOTED}

Beautiful pot plants for the home or greenhouse, also valuable for bedding. They flower in great profusion throughout the Summer and Fall until frost. Start in March or April in pots in the house or in hotbeds for outdoor flowering. Set bulbs with tops slightly covered and water sparingly until plants are growing. Prefer a moist, partly shaded place, sheltered from strong winds.

Single Varieties. In separate colors, rose-pink, salmon, yellow, white, pink, orange. Large bulbs each, 25c., doz., $\$ 2.75$; mixed, 'each, 25c., doz., $\$ 2.50$.

Double Varieties. Orange and yellow, rose, salmon, scarlet, white, large bulbs. Each, 30c., doz., $\$ 3.00$.

\section{GLOXINIA}

A bulbous greenhouse or indoor plant producing large, funnel or trumpet-shaped flowers of exquisite beauty. Bulbs may be potted up in a mixture of equal parts of peat, loam and sand. Start with a light watering and increase supply as plant grows. After blossoming moisture may be gradually withdrawn, not allowing the bulb, however, to become wholly dried off. After a resting period the bulb will start new.

Mixed Hybrids. Each, 35c.

\section{PEONIES}

While we have many customers who inquire for Peony roots for Spring planting, and while we would gladly furnish them at that time, we wish to impress on them the advisability of Fall planting. Clumps of medium size, planted in the Fall will flower the following Spring, whereas, clumps planted in the Spring will not blossom as a rule until the following year. Peonies are one of the most popular hardy garden plants. They will stand the most severe weather with little or no protection. During June they will afford a display that is unequaled. Every garden should have a few clumps of these beautiful rose-scented flowers.

Cultural Directions.-Peonies thrive best in rich soil. Add manure, poultry droppings, or any other form of fertilizer, while the plants are dormant. Do not set the clumps more than 3 inches below the surface of the soil. Most Peony growers advise the moving and dividing of the roots every five to six years. A falling off in bloom indicates that the plants need moving or that there is lack of fertilizer. The presence of ants while the plants are in bloom need cause no alarm as they do not seem to do any harm.

We offer the following varieties as being among the best of their respective colors. They are all rose-perfumed and excellent keepers. This makes them especially fine for cutting.

Festiva Maxima. Very large globular blossom. Pure white-flecked crimson.

Boule de Neige. Pure white. Large, fragrant.

Duchesse de Nemours. White, yellow center.

Louis Van Houtte. Deep red.

Francis Ortegat. Red with yellow stamens.

Edulis Superba. Silvery pink.

Rose Aimeable. Very large. Rose pink.

Madame Forel. Violet rose. Lavendar pink when fully open.

Queen Victoria. White. Outer petals, light pink.

Good Planting Roots, 50 cts. each.

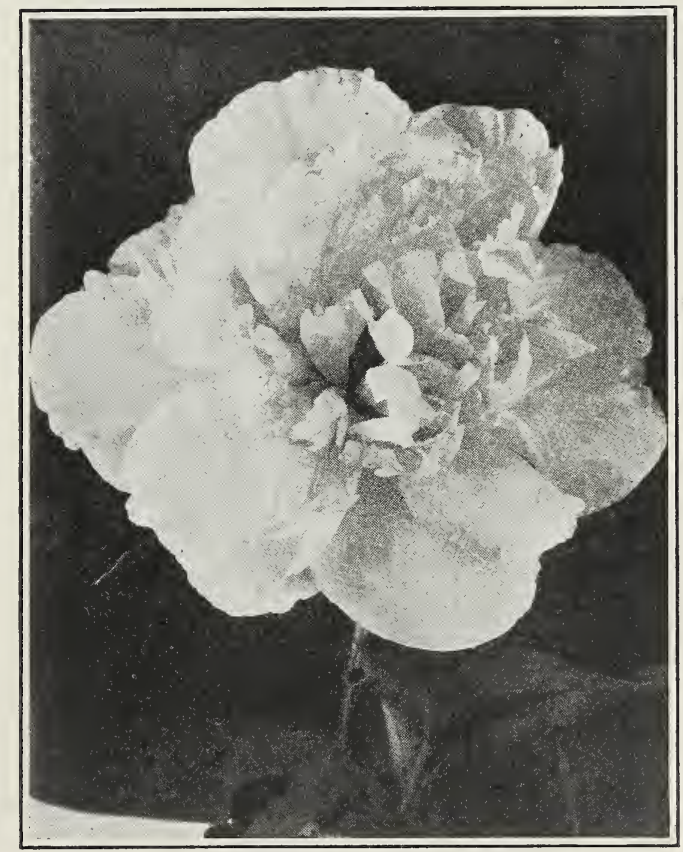

Peony Queen Victoria 


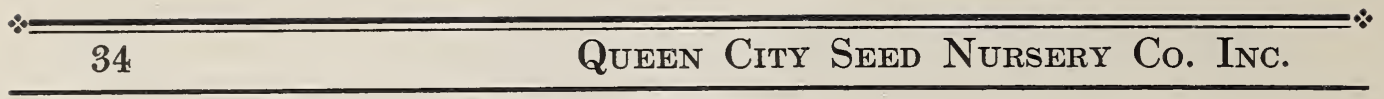

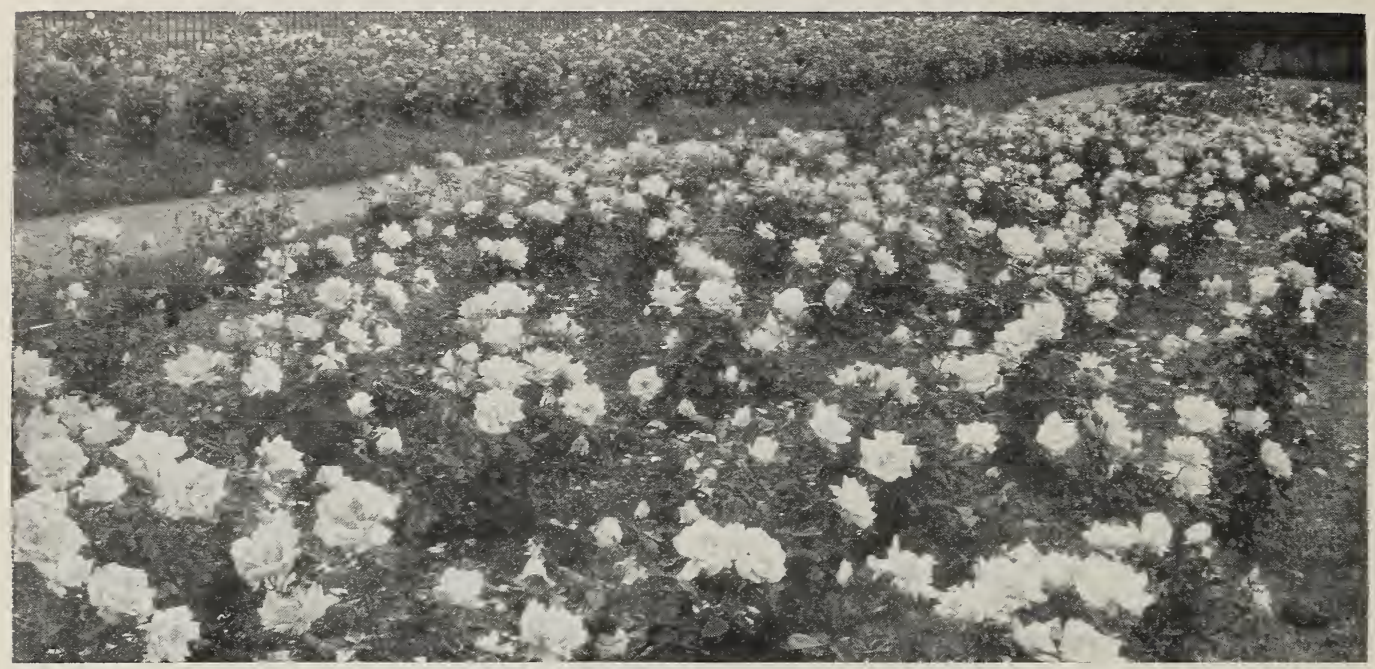

Killarney Roses

\section{Selected Hardy Garden Roses}

Roses should be planted as early in the Spring as the ground can be worked. Handle carefully as they need attention when planted. They require a good sunny location, well drained and rich soil. When making the bed it is well to take out the soil to a depth of 18 inches to 2 feet and fill in well rotted cow manure to the depth of 10 to 12 inches and then replace top soil. Press down firm and then set the bushes a little lower than they were in the nursery, covering the graft 3 to 4 inches to prevent suckering as much as possible. Prune back to two or three eyes on each stalk, as all flowers are borne on new wood.

\section{Hybrid Perpetual, or June Roses}

\section{Strong, dormant 2-year old plants. Each 75 cents.}

Frau Karl Druschki. Snow white; buds perfectly formed. Two crops of blooms each season. Fine for cutting as it lasts well.

General Jacqueminot. Brilliant crimson scarlet; superb flowers, very fragrant. Good for all purposes.

Marshall P. Wilder. Deep rich, glowing red. Extra large, semi-globular, full. Very strong grower and free bloomer.

Magna Charta. Bright rose, very large. Blooms early in the season; sweet scented and fine texture.

Margaret Dickson. White, with pale flesh center. Petals very large and shell-shaped. A fine variety.

Mrs. John Laing. Soft pink, abundant bloomer; large flowers of fine form and lasting well. A variety of especial merit.
Harrison's Yellow. A deep golden yellow.

Mrs. R. G. Sherman-Crawford. Deep, rosypink, white at base of petals. Distinct from all other H. P. Roses and one of the finest grown.

Paul Neyron. Deep Rose, largest of all roses; fine foliage. Free blooming.

Ulrich Brunner. Brilliant, cherry-crimson flowers of immense size and bold, globular form. Long blooming season.

Persian Yellow. A fine deep golden yellow. Double flowers.

Crested Moss. Rose color, beautifully crested. 


\section{Hardy Everblooming Hybrid Tea Roses}

These have been produced by crossing the free blooming Tea Roses with other varieties, principally the June flowering or Hybrid Perpetuals, thus combining the hardiness of the Hybrid Perpetuals with the free blooming habit of the Teas. Hybrid Teas need protection during the Winter by mounding the soil about the stems to a height of 8 or 9 inches, just before the frost, and then cover entire bed with leaves or straw. You may put a 12-inch fence of poultry wire around the bed and fill in with leaves and then put on a few boughs to hold the leaves. Do not remove covering until all danger of frost is past. Prune back to 6 to 8 inches in Spring. Strong, dormant 2-year old plants. Each \$1.00, except as noted.

American Beauty. A well known variety. Deep rosy carmine in color and very fragrant. Quite hardy in all localities.

Columbia. A splendid, large, full double Rose. Very lasting. A strong grower and almost thornless. Brilliant rose-pink.

Gruss an Teplitz. Bright, scarlet-crimson, velvety texture. Very free flowering and vigorous in habit.

Gen. McArthur. Bright crimson, one of the best red roses for bedding purposes. Not subject to mildew. Long blooming.

Hoosier Beauty. Buds long and slender, flowers large and full. Glowing crimson with dark shadings.

Jonkheer J. L. Mock. A rose of giant size. Enormous deep rose colored blossoms on strong vigorous stems, a grand garden rose.

Killarney Pink. A vigorous rose. Long pointed buds, bush pink suffused with pale pink.
Los Angeles. A magnificent Rose in color, form and fragrance. Buds are long and pointed, expanding into a large flower. Color is flame-pink with coral and gold at base of petals. Price, $\$ 1.25$.

Lady Hillingdon. Deep apricot yellow. Long pointed buds in large numbers. Fine shape.

Mrs. Aaron Ward. A distinct Indian yellow shading lighter towards the edges. A strong compact grower.

Duchess of Wellington. $\left\{\begin{array}{l}\text { Intense saffron-yellow } \\ \text { stained, deep crimson } \\ \text { changing to deep saffron- } \\ \text { vellow as flowers develop. } \\ \text { Very free flowering. }\end{array}\right.$

Mme. Caroline Testout. Bright, satiny rose, with brighter center. Free flowering.

Ophelia. A delicate Rose, opening to a beautiful salmon-flesh pink, shaded with rose. A long bud on good stems.

Sunburst. A magnificent giant yellow rose. Of fine quality and a good bloomer.

\section{Climbing Roses}

Strong, dormant 2-yr. plants, each 75 cents.

Climbing American Beauty. A new climber, wonderful beauty. Flowers are early, a deep rosy carmine, with shaded center of rich carmine-crimson. Vigorous growing. Succeeds in almost any location.

Crimson Rambler. The best known of the climbing Roses, and an old favorite.

Dr. W. Van Fleet. Buds are pointed and of a flesh pink on stems 12 to 18 inches long; splendid on cutting.

Dorothy Perkins. Soft light pink. Flowers in large clusters, very lasting.

Excelsa. Intense crimson, with lighter edges; fine foliage.

White Dorothy. Clear, silvery white with bright yellow stamens which add to the attractiveness of the flowers. Free bloomer. Very hardy.

Paul's Scarlet Climber. A wonderful scarlet that does not fade. Flowers medium size, semidouble in clusters of three to twenty flowers. Strong climbing habit and very hardy.

Yellow Rambler. Flowers medium size, cupshaped, blooms in large clusters, lasting three to four weeks. Color, light yellow.

Baby Rambler. A deep crimson similar to a Crimson Rambler, but a dwarf type.

Train Climbing Roses on face of trellis or fence so that when Winter comes they may be laid down and the snow be allowed to cover them. This prevents Winter killing and gives nice green stalks for quick growth in the Spring.

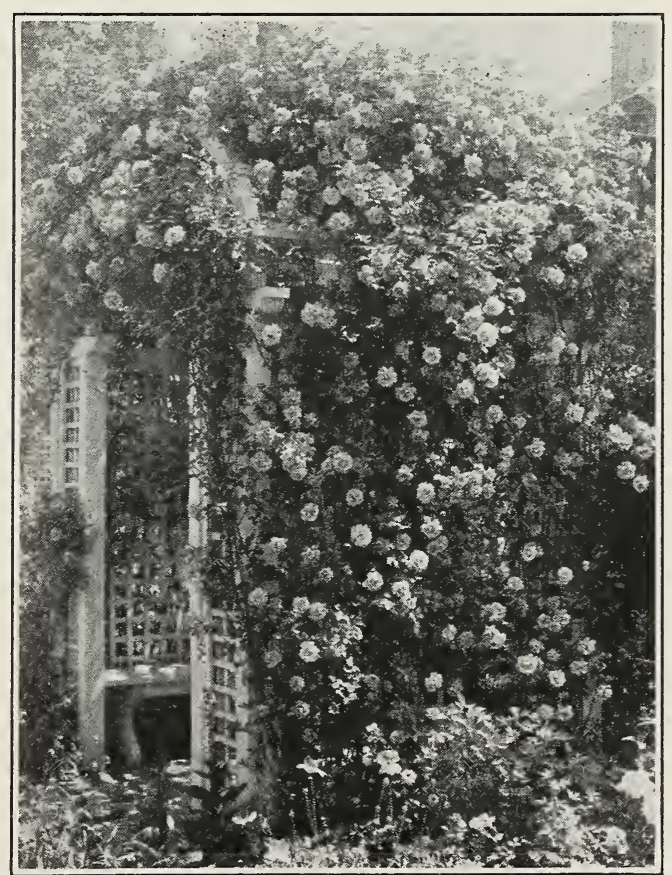

Climbing American Beauty 


\section{Perennial Plants}

The great interest in the old-time favorites of our mothers' and grandmothers' gardens has led us to grow in our own nurseries a choice assortment of perennials for Spring planting. These are from the choicest seed obtainable, either of our own selection from specimen plants, or from specialists in the growing of perennial seeds. We have included in this list a few biennials (H. B.) as they are planted and grown in the hardy border with perennials (H.P.).

ACONITUM Napellus (Monk's Hood). H.P., 4 feet. Helmet-shaped blue flowers. Does well in shade. One of the best of the blue perennials. Each 25c., doz., \$2.50.

ACHILLEA (Milfoil, or Yarrow). A fine, hardy plant, covered with white flowers June to September, 2 feet high.

Ptarmica fl. pl. (The Pearl). Double flowering. Each 25c., doz., \$2.50.

ALTH $Æ$ A, or HOLLYHOCK. Alleghany Single and Double Mixed H.P., 6 to 8 feet. Make a fine background next to a building, high wall or fence, or a fine row in a garden. The double varieties are very desirable, but the new semi-double and fringed types are also very popular. Colors from pure white to deep red. Each, 20c., doz., \$2.00.

ALYSSUM, saxatile compactum (Basket of Gold). H.P., 1 foot. In the Spring each plant is a mass of golden yellow flowers. Each, 25c., doz., $\$ 2.50$.

ANEMONE (Wind Flower). H.P., 9 inches. Poppy-like flowers in Spring, brilliant and showy. Fine for bouquets. Each, 25c., doz., $\$ 2.00$.

Whirwind. White.

Queen Charlotte. Pink.

Japonica Rubrum. Red.

Japonica Alba. White.

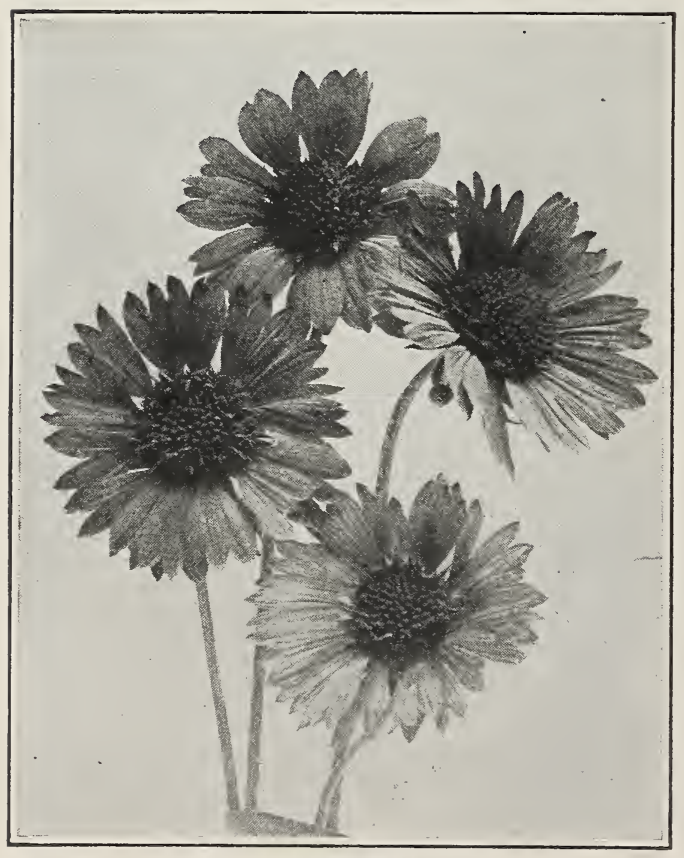

Gaillardias
ANTHEMIS (Hardy Marguerite). 2 feet. A most satisfactory hardy perennial bearing Daisylike golden yellow flowers all Summer. Excellent for cutting. Each, 25c., doz., \$2.50.

ANCHUSA (Alkanet).

Italica (Dropmore variety). Star-shaped flowers of rich gentian blue. May and June. Desirable in hardy borders. Each, 25c., doz., $\$ 2.50$.

Pyramidalis. (Chimney Bellflower). Porcelain blue.

Persicifolia. (Peach Bells). 2 feet high. Blue flowers.

AQUILEGIA. caerulea hybrids (Columbine). H.P. Charming, hardy plants, bearing in May and June countless exquisite blossoms in blue, white, rose, yellow, purple and striped. Thrive in ordinary garden soil, but do best in partial shade.

Each., 25c., doz., $\$ 2.50$.

BOCGONIA (Plume Poppy).

Cordata. A beautiful plant well adapted to planting in shrubbery borders or massing for effect. Creamy white Poppy-like flowers, 6 to 8 feet. July and August. Each 25c., doz., \$2.50.

BOLTONIA (False Chamomile).

Latisquama. Pinkish lavender Aster-like flowers in great profusion. August and September; 4 to 5 feet. Each, 25c., doz., \$2.50.

CAMPANULA. H. P. This old-fashioned stately and showy flower is a favorite with all. Easy to grow. Transplanted in the Fall to a permanent location and covered lightly with evergreen branches, straw or coarse hay, after ground freezes they will come through the Winter nicely.

Medium calycanthema (Cup and Saucer).

Rose, Pink, White and Mixed Colors. Each, 25 c., doz., $\$ 2.50$.

CHRYSANTHEMUM, Hardy. Planted in sheltered locations at the base of walls, buildings, shrubberies, etc., they are wonderfully satisfactory, making an effective display after other garden flowers are destroyed by frost.

We have the following: Each Doz. Autumn Glow. Red...........\$0.25 \$2.50

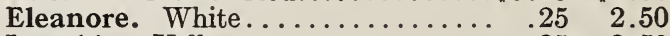

Lenobia. Yellow................... .25 2.50

Rosea. Pink............... .25 2.50

COREOPSIS. lanceolata grandiflora. H.P. A fine, hardy plant with large bright yellow flowers produced in great abundance from June to frost. One of our showiest perennials. Each, 25c., doz., $\$ 2.50$.

DELPHINIUM (Larkspur), H.P., 4 to 6 feet. One of the most exquisite and effective flowers we have for beds or massing. Splendid in combination with white Lilies (Madonna, or Candidum). Plant 1 to 2 feet apart.

Belladonna. Clear turquoise-blue. Each, 25c., doz. $\$ 2.50$.

Hybrids, English. Various shades of blue. Each, 25 c., doz. $\$ 2.50$. 
DIGITALIS gloxiniaeflora (Foxglove). Mixed colors. White, Pink, Lilac and Purple. Each 25c., doz. $\$ 2.50$.

DIEL YTRA. (Bleeding Heart). An old fashioned favorite. Heart shaped pink flowers. Strong clumps Each, 50c.

EUPATORIUM. Coelestinum. Light blue flowers similar to Ageratum. Flowers Aug. to frost. 18 to 24 inches. Each, 25c.

FUNKIA (Plaintain Lily).

Subcordata Grandiflora. Large, white, lily shaped, fragrant flowers Aug. to Sept. Each 25c.

GAILLARDIA grandiflora. H.P., 1 to $1 \frac{1}{2}$ feet. Among the showiest and most effective hardy plants. Large, showy flowers. Should have a place in every hardy border. Require but little protection and thrive in almost any soil. If kept picked will bloom until frost. Mixed. Each, 25c., doz., $\$ 2.50$.

\section{GRASSES. Ornamental.}

\section{Eulalia. Spike grass.}

Eulalia. Zebrina. Striped crosswise.

Eulalia. Japonica variegata. Striped lengthwise. Each, 25c. doz. $\$ 2.50$.

GYPSOPHILIA paniculata (Baby's Breath). H.P. Pure white. Plants make fine clumps for garden use. Each 25c., doz. $\$ 2.50$.

HELENIUM (Sneezewort).

autumnale superbum. Golden yellow flowers in broad-spreading heads, during late Summer and early Fall. 5 to 6 teef. Each 25 c., doz. $\$ 2.50$.

HEMOROCALIS. Yellow Day Lily. Popular hardy plants belonging to the Lily family. Succeed everywhere. Each 25c.

HOLLYHOGK. Double. Red, maroon, yellow, white, pink, and mixed. Each 20c.

L YCHNIS. H.P., 2 feet. Brilliant flowers, shaped like a Maltese cross; 1 foot high. May and June.

Viscaria. Pink. Chalcedonia. Red. Each, 25c. doz. $\$ 2.50$.

LUPINUS. Large spikes of flowers. May and June. Blue, white, yellow and mixed 25c. each. $\$ 2.50$ doz.

LOBELIA. Cardinalis. Rich cardinal flowers on spikes 24 to 30 inches long. Each, 25c. $\$ 2.50$ doz.

MONARDA (Bergamot) (Horse Mint).

didyma. Showy plant, 2 to 3 feet high, with compact heads of bright red flowers, during June to August. Foliage fragrant. Each, 25c., doz., $\$ 2.50$.

M YOSOTIS (Forget-Me-Not).

palustris semperflorens. This variety remains in flower a long time. Color blue. Good for shady spots in the rock garden; 10 inches high. May to September. Each, 25c., doz., $\$ 2.50$.

\section{PACHYSANDRA.}

terminalis. Small white flowers. Foliage deep green; evergreen. Excellent where a green carpet is required. Looks well on graves, around shrubs, and under trees where grass will not grow. Each, 30c., doz., \$3.00.

\section{IRIS}

GERMAN IRIS (Iris germanica). These are among the most desirable and easiest grown of our early flowering hardy plants. Flowers are of exquisite coloring. Best results are obtained by planting in well drained, sunny locations, barely covering the roots. Avoid use of manure.

Celeste. Falls, bright blue; uppers, delicate grayish blue, all having a lavender effect.

Edith. Standards, light blue; falls, purple.,

Fulda. Satiny white, lower petals lilac, feathered yellow.

Her Majesty. Standards, old rose; falls, white, striped rosy lilac. A very large flower.

Innocence. Pure white, penciled purple and orange.

Madame Chereau. White, elegantly frilled with a wide border of clear blue.

Madame Pacquette. Rosy claret.

Mrs. H. Darwin. Satiny white, veined crimson.

Queen of May. Very dainty, soft rose-lilac almost pink.

All: Each, 25c., doz. $\$ 2.50$.

JAPANESE IRIS (Iris Kaempferi). This beautiful flower, in its improved form, is as popular as the Peony and the Phlox. It blooms about the middle of June and continues for four to five weeks. Succeeds in almost any soil, but rich soil and plenty of water when flower-buds are forming gives heavier blooms and larger flowers. Splendid for cut flowers. Cut in the bud state the blooms open after being placed in water. Various colors. shades and markings.

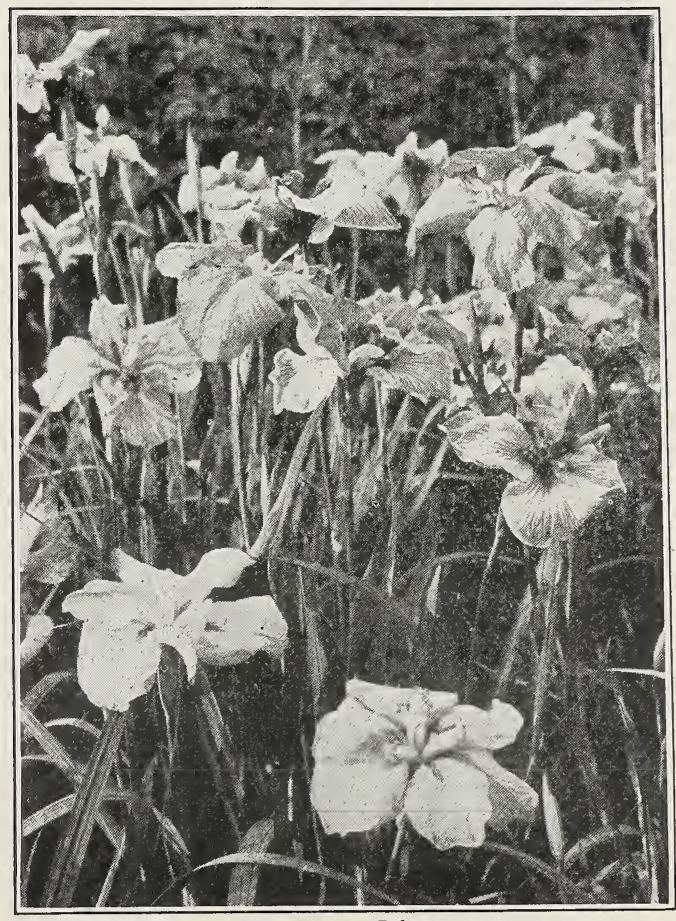

Japanese Iris 
Gekka-no-mami (Waves under Moonlight). Glistening white, with creamy white stigmas. Each, 25c., doz., $\$ 2.50$.

Kumo-no-obi (Band of Cloud). Bright clear purple with halo and rays of white; throat golden and standards white, tipped with purple. Each, 25 c., doz., $\$ 2.50$.

Momiji-ne-taki (Maple Waterfall). Double variegated variety, bright crimson purple, feathered in white. Each 30c., doz. $\$ 3.00$.

Purple and Gold. Double large flowers, often 10 inches across, and free blooming. Color, rich violet with white petals, tipped with violet. Throat golden. Each 25c., doz. $\$ 2.50$.

PHYSALIS. (Chinese Lantern). Each 25c.

PHLOX. In variety. Each 25c., doz. $\$ 2.50$. A few of the named varieties are the fullowing:

Eliz. Campbell. (Salmon pink).

Beacon. Deep pink.

Thor. Pink, deep eye.

Antoni Merie. Lavender.

Iris. Blue.

Coliquet. Scarlet.

Rynstrom. Pink, deep eye.

Bridesmaid. Pink and white.

Struthers. Deep pink.

Lingard. White.

Pearl. White. Each 25c. doz $\$ 2.50$.

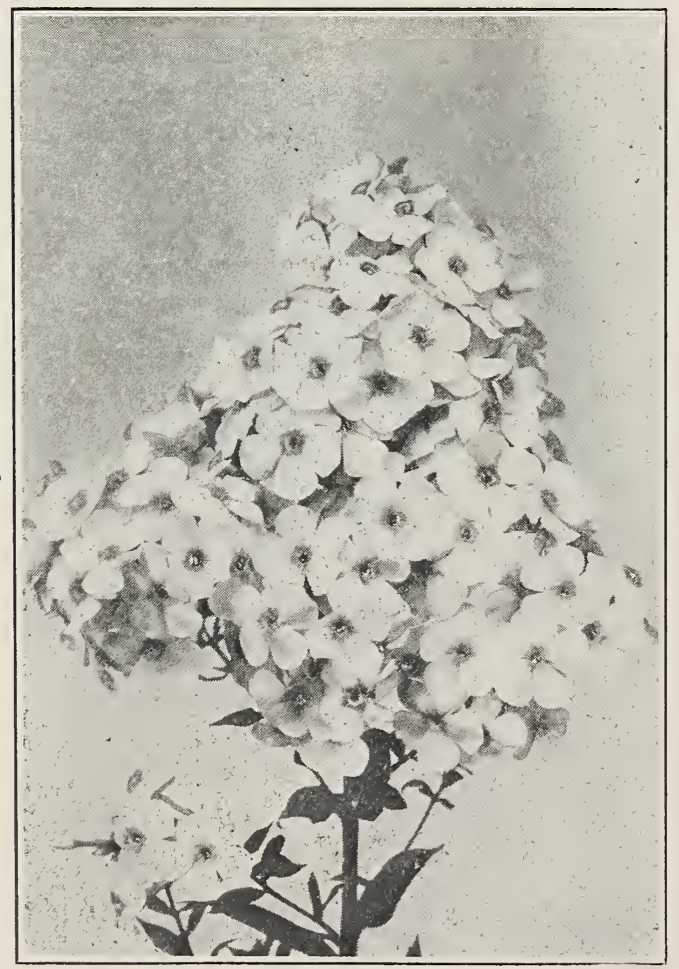

Phlox
POPPY, Oriental. H.P. For permanent beds they are unequaled. Effective among shrubbery. Tall growth; large, showy, scarlet flowers. Each, 25 c., doz. $\$ 2.50$.

Iceland. H. P. A graceful plant with bright green, fern-like foliage. The flowers are borne on 12-inch stems. Pick off seed pods and they will bloom the entire season. Mixed colors. Scarlet, orange, white, etc. Each 20c., doz. $\$ 2.00$.

PYRETHRUM. roseum hybridum. H.P. Useful in borders. Fine, Daisy-like flowers useful for cutting. Come in a variety of colors borne in great profusion in May and June and again in the Fall. One of the most graceful and long-lasting cut flowers. Each 20c., doz. \$2.00.

Double Flowering. In crimson, pink and white. Each 50c.

POL YANTHUS. English Mxd. Hardy spring flowering primrose. Each 35c.

RUDBECKIA (Cone Flower).

purpurea (Grand Purple Cone Flower). Bushy plants 3 feet high, blonms July to October. Flowers 4 inches across, of a reddish purple color with brown center. Each, 25c., doz., $\$ 2.50$.

laciniata, fl. pl. (Golden Glow). Double yellow flowers. August and September; 6 feet. Each 25c., doz. $\$ 2.50$.

\section{SALVIA.}

azurea grandiflora. A Rocky Mountain species with sky blue flowers; 3 to 4 feet. August and September. Each, 25c., doz. $\$ 2.50$.

\section{SCABIOSA.}

caucasica (Pincushion Flower). Handsome, hardy plant and should be grown by everyone; beautiful soft lilac flowers; 2 to 3 feet. June to August. Each 25c., doz. $\$ 2.50$.

SHASTA DAISY (Hardy Chrysanthemurn). H.P Bushy growth. Bears a profusion of immense white flowers on long stems. The blooms are very lasting and showy. Fine for indoor decoration. Each 25c., doz. $\$ 2.50$.

STOKESIA laevis (Cornflower, Stokes' Aster). H.P., 18 inches. Handsome Cornflower-like flowers, 4 to 5 inches across. July to October. Easy culture and most desirable for the hardy border. Mixed colors. Blue and white. Each 25 c., doz. $\$ 2.50$.

SWEET WILLIAM (Dianthus barbatus). H.P. The merits of this sturdy, old-fashioned flower are becoming more generally recognized. Beautiful, fragrant and easily grown. Large heads of flowers and wide range of colors. Each 15c., doz. $\$ 1.75$.

TRITOMA. (Red Hot Poker). Blooms Aug. to Oct. orange-scarlet spikes 3 to 4 feet high. Each 30c.

VERONICA (Speedwell).

longifolia subsessilis. Blue. A very beautiful herbaceous plant. Very attractive. Blooms until late Fall. August; 2 feet. Each 25c., doz. $\$ 2.50$.

YUCCA (Adams' Needle).

filamentosa. Of tropical appearance with sword-like foliage and pyramidal clusters of creamy white flowers; 4 to 6 feet. June and July. Each 25c., doz. $\$ 2.50$. 


\section{Flowering and Ornamental Shrubs}

Shrubs are not particular as to location, although some of the blossoming varieties require more care than others. The time of bloom for the greater number is in the Spring, although some come later, prolonging the blooming period. The variegated and golden leaved sorts, together with those bearing ornamental fruit, will make a varied display.

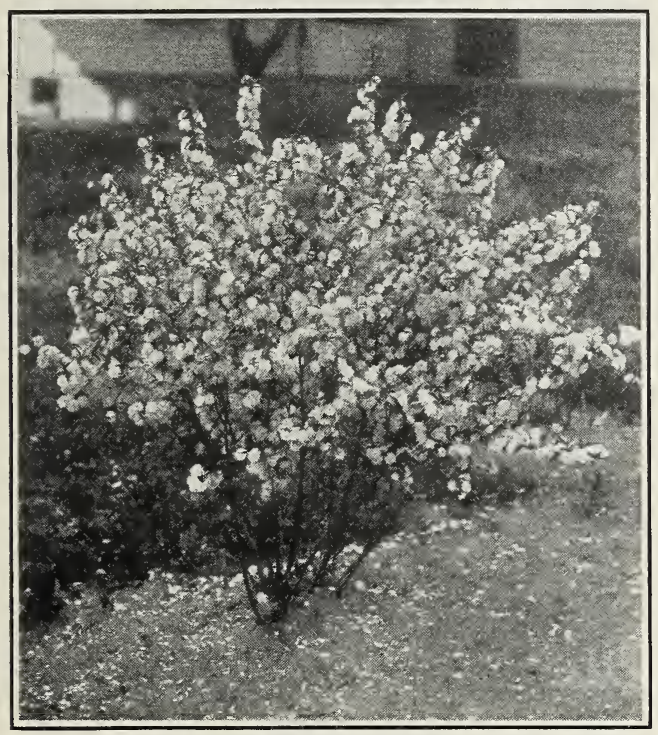

Flowering Almond

ALMOND, Flowering. A bushy, shrub, or dwarf tree rarely over 5 feet tall, bearing rose and blush colored double flowers in early Spring. Hardy and very attractive. Heavy plants. Each, $\$ 1.00$.

ALTHÆA, or Rose of Sharon. Bush form. White, red, pink and purple. An attractive, hardy shrub with large, showy blossoms. Excellent for a flowering hedge or to grow singly. Each, 50c. Tree form, Each 80c.

ARALIA (Angelica Tree, or Hercules' Club). A. spinosa. Prickly stems and immense panicles of snow-white flowers in August. Each 50c.

AZALEA. Hardy varieties Lutea. Yellow.

Canensis. Native semi-dwarf. White.

Rosea. Red. $\$ 2.00, \$ 2.50$ and $\$ 3.00$ each according to size.

BERBERIS. Thunbergii, or Japan Barberry. One of the best lawn or border shrubs. Compact, low growing and especially suitable for a hedge or a border along walks and drives or in front of low verandas. Foliage a deep green, turning red in the Fall, followed by scarlet berries.

Small 25c; $\$ 2.50 \mathrm{doz}$.

Large 40c; $\$ 4.50 \mathrm{doz}$.

BUDDELIA (Butterfly Bush). Violet colored flowers in slender, drooping panicles. A charming and graceful plant. Each, 75c.

BURNING BUSH, or STRAWBERRY TREE (Euonymus europaea). European Burning Bush. Forms a tree sometimes 30 feet high. Fruit rose colored. Hangs on late in fall and is very ornamental. Each, 90c.
CATALPA Bungei. A dwarf variety with attractive round head. Desirable for small lawns and formal gardens. Each, $\$ 2.00$.

CAL YCANTHUS, Carolina Allspice, or Sweet Scented Shrub. Handsome plant, tall with large, glossy foliage and spicy, fragrant, chocolate-red flowers about 2 inches iacross. Does well either in sunny or shady location. Each 50c.

CHERRY. Double Flowering Pink. A beautiful tree-shaped shrub, similar in form to the Flowering Almond, but more free growing. Covered in spring with double pink button-like flowers. 3 to 4 feet, $\$ 1.50$.

CLETHRA, Alnifolia. Sweet pepper bush, white flowers in fragrant spikes. Dense, low growing shrub. Each 50c.

GRAB, Bechtel's Double Flowering. A tree of medium size with flowers of large size and beautiful pink color. Resembles a fragrant double pink Rose. Each, $\$ 1.50$.

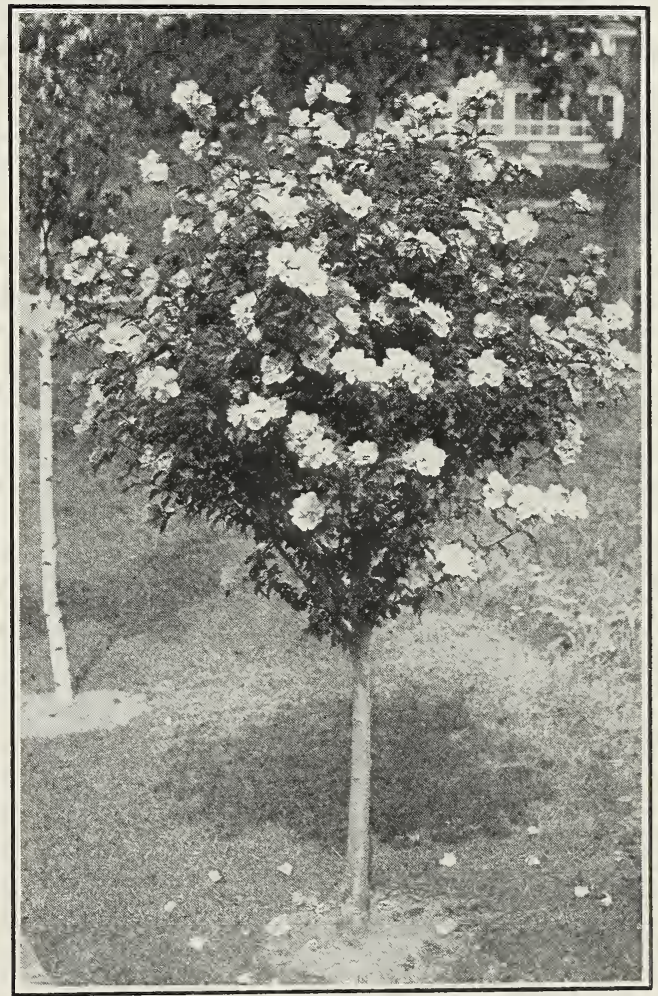

Al thea 


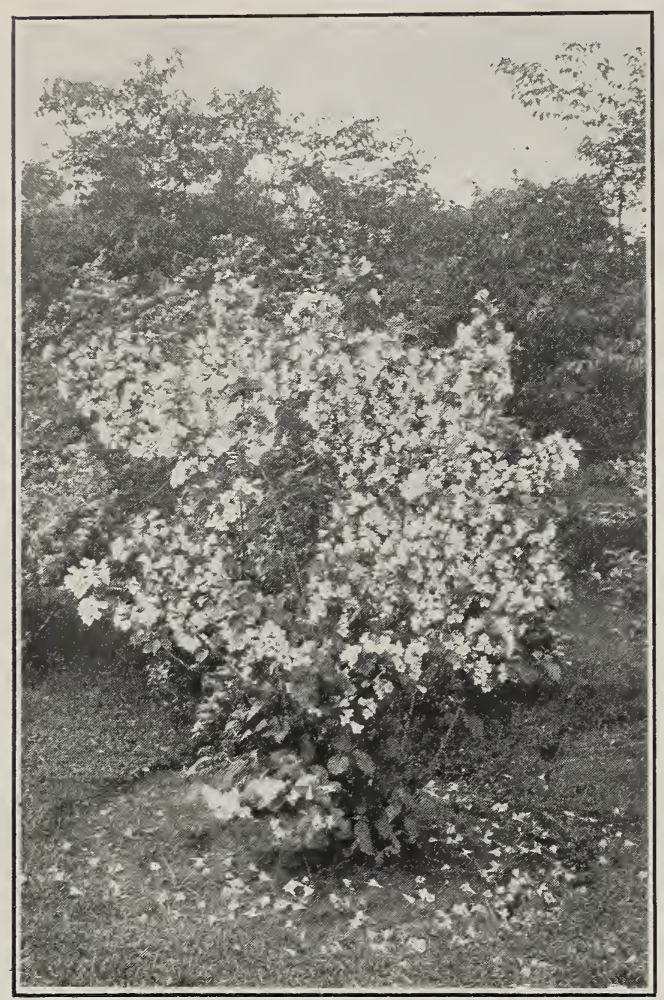

Diervilla or Weigela

CORNUS, or Dogwood. Hardy shrubs with handsome foliage, often turning a brilliant red in the Fall and with attractive flowers and fruits. The red and yellow branched varieties are especially attractive in Winter.

Mascula, or Cornelian Cherry. Yellow flowers in April before leaves appear and scarlet fruits in Autumn. Blooms very early. Each 50c.

Lutea. Golden or yellow bark. White blossoms. Each 50c.

siberica, or Siberian Dogwood. Rapid growing shrub with white flowers in May and June and bright red bark in Winter. Each $50 \mathrm{c}$.

COTONEASTER. An upright and dense growing shrub. Dark green leaves and showy bright red berries borne along the stems, 4 to 5 feet. Each 50 c.

CYDONIA japonica, or Japanese Quince. A handsome and ornamental shrub. Covered with bright red flowers early in Spring before the leaves appear. Foliage bright glossy green and remains all Summer. One of the best hardy shrubs. Each 80c.

DEUTZIA. Very ornamental and popular shrubs, with snowy white or pinkish flowers in tassel-like clusters in Spring, and early Summer. Thrive in almost any soil and well adapted to borders and shrubberies. D. Lemoinei is the hardiest white. D. gracilis and D. crenata require light protection.

Pride of Rochester. A fine variety, large double white flowers tinged with rose. Blooms early in June. Each 50c. crenata. Tall, up to 6 feet. Blooms in advance of others. Large double pink flowers. Each 50c. gracilis. Low growing, 3 feet high. Slender arching branches, bright green leaves. Snow white flowers. May and June. Each 60c.

DIERVILLA, or Weigela. Beautiful shrubs, blooming in May, June and July. Trumpet-shaped flowers, very abundant and close together. Very desirable for the border or for grouping.

candida. White flowers, Each 60c.

Amabiles. Pink. Each 60c.

rosea. Rose-colored flowers, Each 60c.

Eva Rathke. Large crimson flowers. Each 80c. Desboise Rose. Each 60c.

ELDER, or Sambucus. Beautiful leaves as well as flowers and fruit. Bloom in June. Requires vigorous pruning.

Golden Elder. (Yellow-leaved nigra aurea). Each 50c.

FORSYTHIA, or Golden Bell, suspensa. One of the showiest early flowering shrubs, with brilliant yellow flowers in great numbers appearing before the leaves; 8 to 10 feet high. Each 50c.

Fortuneii. Growth upright. Flowers bright yellow appearing before the leaves. 8 to $10 \mathrm{feet}$, Each, 50c.

HONEYSUCKLE, or Lonicera. Shrubs of upright habit, with fragrant flowers and red berries. Thrive in almost any garden soil, preferring sunny location. Prune during the Winter.

Morrowii. Yellow flowers followed by red fruits. Each 50c.

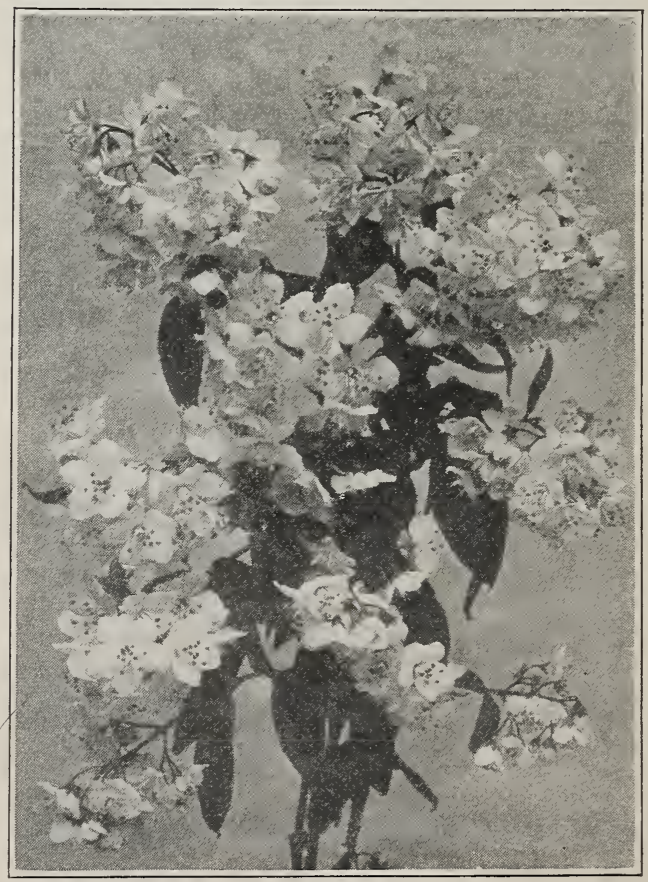

Deutzia 


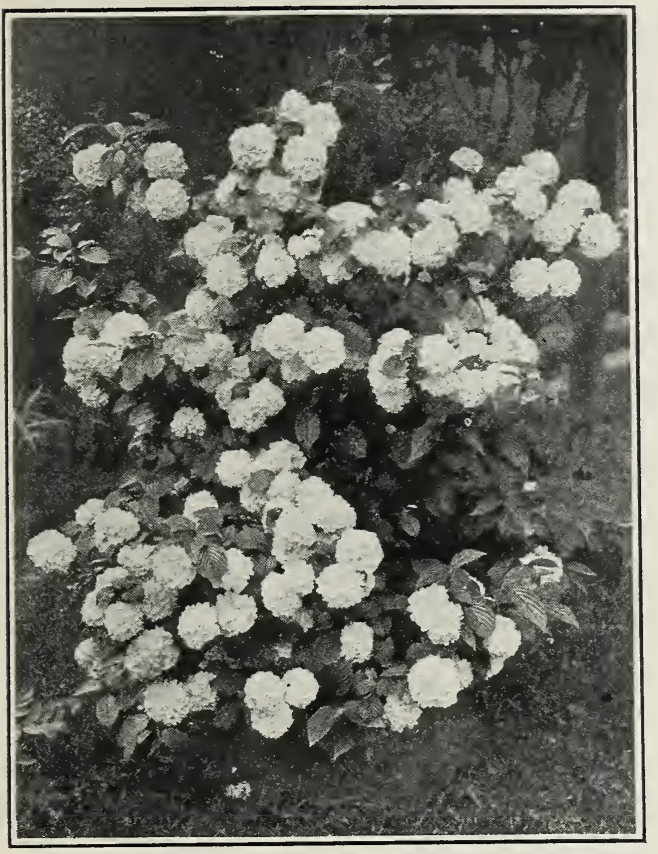

Japan Snowball,Viburnun plicatum

tartarica alba. Produces an abundance of fragrant white blossoms in May and June, followed by yellow berries. Each 50c.

tartarica rubra. Bright red flowers followed by red fruit. Each 50c.

HONEY LOGUST. Gleditschia. A rapid growing hedge plant. Has delicate attractive leaves and powerful spines. A good defensive hedge. Each 25c.

HYDRANGEA. One of the best and most reliable shrubs, giving a large number of showy white flowers in August. To secure large clusters of blossoms, prune in Fall or early Spring to 2 or 3 buds on each branch.

arborescens (Snow Hydrangea). The snowwhite blooms are much like the snowball flower, but larger and more attractive. Coming into bloom after the Spring blooming shrubs have finished makes it valuable for the garden. Each 80c.

paniculata grandiflora. A most popular and widely planted shrub, perfectly hardy, standing heat and cold. Flower panicles are white, changing to rose and remain in good condition for weeks. Bùsh form, each 80c. Tree form, each, $\$ 1.50$.

KERRIA, or Corchorus. A shrub with tender, bright green branches which are ornamental even when bare of leaves. Does well in almost any soil and in shade or sun. Excellent for use in front of taller shrubs. Orange-yellow flowers in May and occasionally during the Summer.

japonica. 12 to 18 inches, double yellow. Each $75 \mathrm{c}$.

LIGUSTRUM, or Privet. Very fine for shrubberies or hedges. Have dark green, clean foliage, rarely attacked by insects and stays green until late Fall. Stand the dust and smoke of the city and grows well in almost any soil.
Amurense (Armoor River Privet). Oblong, glossy foliage, small white fragrant flowers, half evergreen. Each 25c.

ovalifolium (Californian Privet). Rapid grower with bright shiny leaves. Grows freely in almost any soil, is compact in form and can be trimmed to almost any shape. Desirable for hedges. Each 12c., $100, \$ 10.00$.

LILAC, or Syringa. One of the best ornamental shrubs for borders or as specimens. Very hardy and will stand neglect and drought. Blossoms in early Spring and are very fragrant.

vulgaris, or common. Tall growing, 8 to 15 feet, with large clusters of fragrant purple flowers. Each 60c.

alba (Common White Lilac). Each 60c.

japonica (Giant Japan Tree Lilac). Leaves thick, pointed and dark. Flowers in very large clusters, creamy white. Each, $\$ 1.00$.

persica (Persian Purple). Native of Persia. Leaves small, dark green. Flowers, abundant, delicate and purple. Each, $\$ 1.00$.

French Red, $\$ 1.00$ each.

French White, $\$ 1.00$ each.

PHILADELPHUS, or Mock Orange or Syringa . Tall, vigorous growing shrubs with an abundance of fragrant white flowers, excellent for cutting. Will thrive well in any well drained soil. Prune after flowering. Cut out branches which are three to four years old. Good for backgrounds and screens.

coronarius (Garland Syringa). One of the best and earliest. Has large clusters of pure white fragrant flowers in May; 6 to 12 feet. Each, 60c.

aurea (Golden Syringa). Medium high. Foliage golden yellow. Each, 60c.

grandiflora. Large flowered. A vigorous, upright grower. Slender branches with an abundance of pure white, fragrant flowers in June. Each, 60c.

PEACH, Flowering (Persica). Double Red Flowering Peach. An ornamental shrub or small tree. A very attractive species of the flowering fruits. Each 60c.

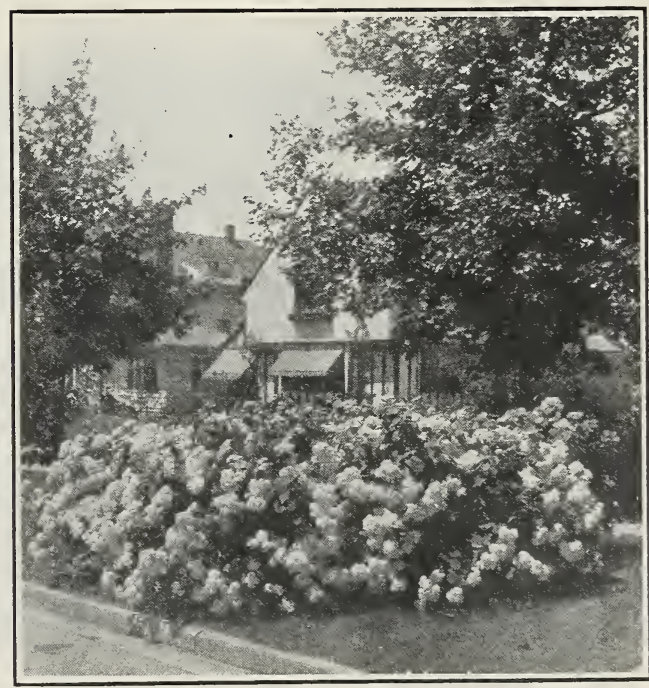

Hydrangea Arborescens 


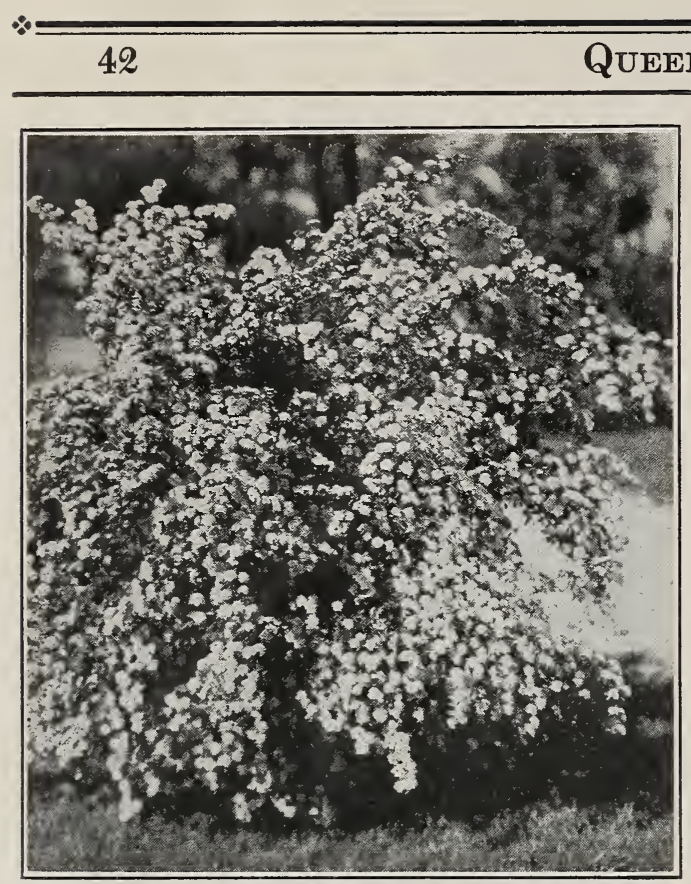

Spirea Van Houteii

PURPLE FRINGE (Rhus cotinus). From the south of Europe. Admired for the curious fringe of hair like flowers covering the surface of the shrub in mid-summer. Each 75c.

PRUNUS, triloba, or Double Flowering Plum. A low growing, hardy shrub with slender branches and double pink flowers in advance of the leaves. Each, \$1.00.

Pissardii (Purple Leaf). Dwarf shrub, single white flowers. Leaves crimson turning to purple. Each $\$ 1.25$.

RHODODENDRON

Maxima. White and pink.

Catawbiense. Purple.

Canadenca. Pink small early, $\$ 2, \$ 3, \$ 4, \$ 5$, and $\$ 6$ each, according to size.
RIBES, or Flowering Currant. Grows 4 to 7 feet high. Flowers yellow and spicy fragrant, borne very abundantly in May. Each 50c.

SPIREA. All are medium size or low shrubs and well adapted for borders or shrubbery. Easy culture and rapid grower. Will grow in almost any moderate moist soil.

S. Billardii. Rose-colored bloom lasting nearly all Summer. Very fine and showy. Each 60c.

S. prunifolia (Bridal Wreath). Beautiful double white blossoms, very profuse. Blooms in May. Foliage scarlet in Autumn. Each 60c.

Van Houteii. One of the best varieties of Spiraea. Bush is round and graceful with long, thin, arching branches. The white flowers are in clusters, and so numerous that the bush is snow white when in full bloom. Each 50c.

Bumalda (Anthony Waterer). A low growing shrub with deep rose colored blooms during the latter part of the Summer. Each 60c.

SYMPHORICARPOS, or Waxberry. For massing in the edge of beds or borders. Will thrive in almost any soil. They hold their fruit late into the Winter.

racemosus, or White Snowberry. Grows to medium size with pink flowers in July, followed by waxy berries in the Fall and early Winter. Each 60c. vulgaris, or Indian Currant. Low growing, spreading and graceful habit and attractive foliage. Beautiful clusters of red berries which last into the Winter. Each, 50c.

VIBURNUM (Arrow Root, or Snowball). A tall growing shrub, leaves broad and elegant. Flowers are pure white and borne in clusters like big balls of snow. Plant is excellent to use in border or as a specimen plant.

plicatum (Japan Snowball). One of the best varieties of Snowball on account of its freedom from plant lice. Each, 75c.

Opulus sterile (Snowball). Globes of pure white flowers. Each 50c.

Opulus (Highbush Cranberry). Foliage yellowish, green. Large white blooms in June. In fall covered with large red berries. Each 75c.

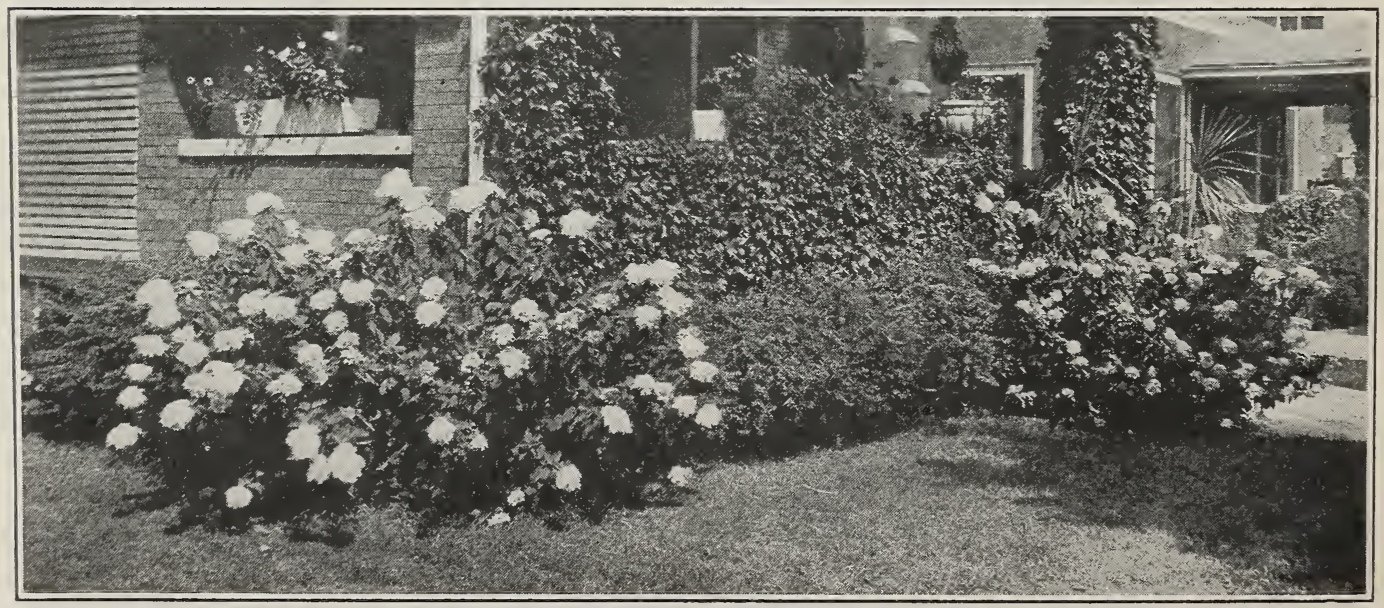

This porch is made inviting and beautiful at small expense. A hedge of Barberry, a few Hardy Hydrangeas and back of them, Ampelopsis vines 


\section{Hardy Climbing Vines}

AMPELOPSIS Veitchii, or Boston Ivy. Very rapid grower. Handsome glossy green foliage turning to orange and scarlet in the Fall. Best vine for covering brick or stone walls. Each $\$ 1.00$.

quinquefolia (Common Woodbine, or Virginia Creeper). Sometimes called five-fingered Ivy. Leaves larger than the Boston Ivy and turn to bright crimson in the Fall. Each 50c., doz. $\$ 5.00$.

ARISTOLOCHIA Sipho, or Dutchman's Pipe. Rapid grower with large heart-shaped leaves and flowers of brownish color, resembling a miniature pipe. Excellent for covering arbors and screens. Each $\$ 1.25$.

BIGNONIA radicans, or Trumpet Vine. Clings to bark or walls. Foliage fern-like, flowers orangescarlet and trumpet-shaped. Each 50c.

CELASTRUS scandens, or Bittersweet. A native climbing or trailing plant or vine with large leaves. Yellow clusters of flowers in May or June, followed by orange-colored berries in the Fall. Each $50 \mathrm{c}$.

CLEMATIS. They need rich, well drained soil, plenty of water, and crowns must be planted 3 inches below surface of ground. Partly shaded position is best. Quite hardy, but it is best to mulch them during the Winter.
Mme. E. Andre. Bell-shaped, heavy-petaled flowers borne in profusion for a long season. Bright scarlet color. Each $\$ 1.00$.

Jackmanii. Very hardy and free growing, with deep purple flowers. Is most satisfactory of its class. Blooms on shoots of the present season, so should be pruned early in the Spring. Each, \$1.00.

paniculata, or Japanese. The best small flowering variety. Rapid grower. Flowers pure white, very fragrant and very abundant. Blooms in September when other vines have finished. Each $50 \mathrm{c}$.

LONICERA, or Honeysuckle (Hall's Japan). A strong growing almost evergreen vine; flowers pure white changing to yellow. Fragrant; covered with bloom from July to November. Each 50c.

LYCIUM, or Matrimony Vine. A well known hardy, fast growing vine with handsome scarlet fruits in the Fall. Used as a ground cover or trailer under trees or on steep slopes to hold soil in place. Each 50c.

WISTARIA. One of the best hardy climbers. Given a sunny location and liberal manuring it grows rapidly and is magnificent in bloom.

chinensis. Delicate violet blue blossoms, richly perfumed. Each 80c.

alba. White blossoms. Otherwise similar to above variety. Each 80 c.

\section{Evergreens}

As our stock of Evergreens is variable as to varieties and sizes, we can only list a few of the most commonly used kinds and heights. If there is anything you are in need of in this class of trees and shrubs, consult us for further information. The best time for planting Evergreens is in April and late August or early September. A little extra care in planting and mulching will be repaid by better growth and less loss.

On all Evergreens if balled and burlapped, add 25 cents each.

\section{JUNIPERIS (Juniper).}

Sabina (Savin Juniper)." A low spreading tree with handsome dark green foliage; very hardy; suitable for lawns and cemeteries; 18 inches. Each, $\$ 6.00$.

Communis Hiberica. Irish Juniper. Erect and tapering, deep green foliage, a pretty little tree or shrub. 12 to 18 inches, $\$ 1.25$ each, 18 to 24 inches $\$ 2.25$ each.

virginiana (Common Red Cedar). Varies in color of foliage. In Summer it is a bright green and in Winter a bronze hue; 18 to 24 inches. Each, $\$ 1.00$.

PICEA (Spruce).

excelsa (Norway Spruce). One of the best evergreens for hedges and windbreaks. A tall tree of perfect pyramidal form. Very popular; 18 to 24 inches, $\$ 1.00$ each; 2 feet, $\$ 1.25$ each; 2 to 3 feet, each $\$ 2.00 ; 3$ to 4 feet, each $\$ 3.00$.

Kosteriana (Koster's Blue Spruce). A beautiful selected strain of the Colorado Blue Spruce; 12 to 18 inches. Each, $\$ 6.00$.
HEMLOCK (Abies canadensis). A beautiful lawn tree, makes a fine hedge; $2 \frac{1}{2}$ feet. Each, $\$ 5.00$.

\section{PINUS (Pine).}

Mugho (Dwarf). An upright, small pine bush; 12 to 18 inches, spread. Each $\$ 5.00$.

\section{THUYA (Arborvitae).}

occidentalis (American Arborvitae). A fine evergreen for hedges and easily transplanted. Grows rapidly and with little care; 12 to $18 \mathrm{inch}, 75 \mathrm{c}$ each; 2 to 3 feet, each $\$ 2.50 ; 3$ to 4 feet, each $\$ 3.50$; 5 to 6 feet, each $\$ 6.00$.

Var. globosa (Globe headed). Grows in a low thick globe form with attractive foliage; 2 foot each, $\$ 4.00$; small, 12 to 18 inch, $\$ 1.00$ each.

Var. pyramidalis (Pyramidal Arborvitae). A beautiful, upright evergreen of compact habit similar to Irish Juniper or erect Yew; 18 to 24 inches, Each, $\$ 2.00 ; 2$ to 3 feet, $\$ 3.00 ; 3$ to 4 feet, $\$ 5.00 ; 4$ to 5 feet, $\$ 6.50$ each. 


\section{Fruit Trees and Small Fruits}

The supply of fruit trees and small fruits is extremely small, due to the heavy demand during the past two or three years and the limited amount of expert help available to nurserymen. The quality of the fruits offered is excellent, however, but is offered subject to being on hand on receipt of order and also subject to change in price.

\section{FRUIT TREES}

\section{APPLES-STANDARD}

\begin{tabular}{|c|c|c|}
\hline Baldwin & McIntosh & Jonathan \\
\hline Spy & Banana & Greening \\
\hline King & $\begin{array}{l}\text { Duchess } \\
\text { Astrachan }\end{array}$ & Wealthy \\
\hline
\end{tabular}

PEARS-STANDARD

Bartlett

Clapp's Favorite

11/16 inches and up. Each, \$1.50.

Seckle

\section{CHERRIES-SOUR}

$11 / 16$ inches and up. Each, $\$ 1.50$.

Early Richmond. Medium, dark red, acid, June.

Montmorency. Large red, productive, 10 days later than Early Richmond.

\section{CHERRIES-SWEET}

$11 / 16$ inches and up. Each, $\$ 1.50$.

Black Tartarian. Very large, black, juicy; last of June.

Rockport. Large pale amber, light red in the sun. Sweet and good. June.

\section{PEACHES}

Crawford

9/16 inches and up. Each, $\$ 1.00$.

Elberta

\section{Yellow St. John}

\section{QUINCE}

2 to 3 feet. Each, $\$ 1.50$.

Orange

\section{Champion}

\section{PLUMS}

11/16 inches and up. Each, \$1.50.

Abundance. Large oblong.

Burbank. Large, clear cherry red, very sweet.

Lombard. Oval, violet red.

German Prune. Large oval, dark purple.

Reine Claude (Bavay's Green Gage). Round, greenish yellow; sugary, rich and excellent.

\section{SMALL FRUITS RASPBERRIES Doz., $\$ 1.00$.}

Cuthbert. Red.

Marlboro. Red. Cumberland. Black.

Columbian. Purple. Saint Regis, Everbearing.

\section{BLACKBERRIES}

Eldorado

$$
\text { Doz., } \$ 1.00 \text {. }
$$

\section{GRAPES}

Concord. Good vines. Each, 25c.

Niagara. Each, 30c.

Delaware. Each, 35c.

Catawba. Each, 30c.

\section{GOOSEBERRIES}

Downing. Green. Each, 25c.

Houghton. Red. Each, 25c.

\section{CURRANTS}

Cherry. Deep red, large. Each, 25c.

Wilder. Red, large. Each, 25c.

White Grape. Large, yellowish white. Each, 25c. re

Black Each, 25c.
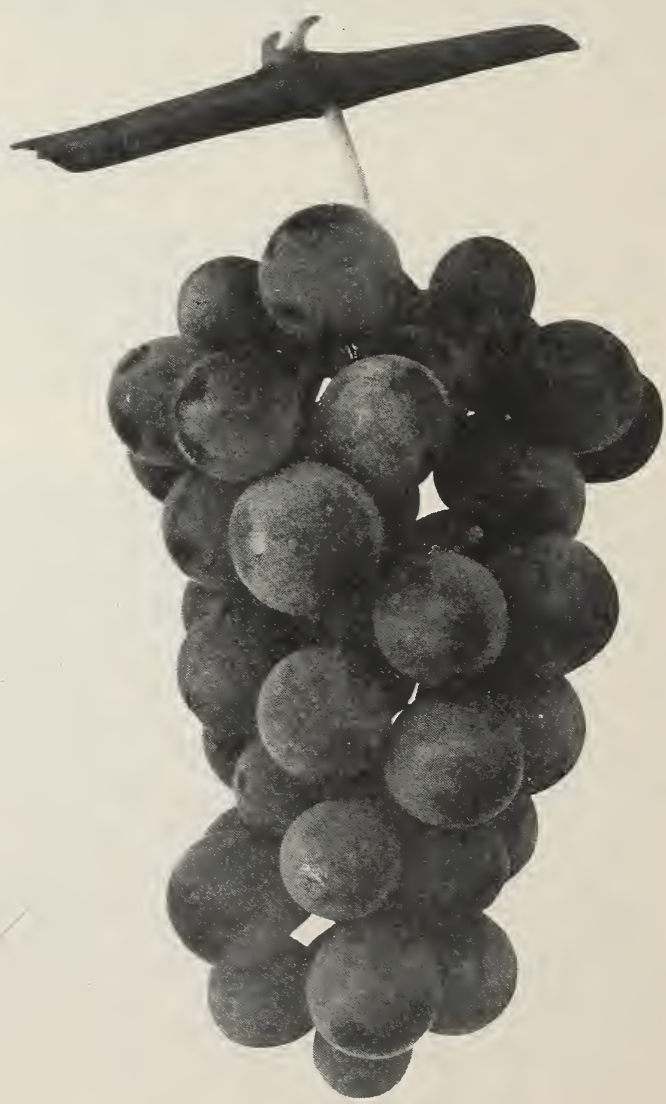

Concord Grapes 


\section{Fertilizers, Etc.}

\section{Prices very variable and subject to change without notice}

Acid Phosphate. Price variable. Ask for quotations.

Alpho Humos. For top dressing lawns and improving garden soils. Per lb. 4c. 100 lbs. $\$ 3.00$ : Special prices on large quantities.

Bowker's Lawn and Garden Dressing. A good all-round fertilizer for the home vegetable and flower garden, for stimulating lawns, etc. 10 lbs. 75 c., 25 lbs. $\$ 1.50$., 50 lbs. $\$ 2.50,100$ lbs., $\$ 4.00$.

Clay's Fertilizer. Imported English Fertilizer largely used by growers and florists. 56 lbs. Bags. $\$ 7.00$. $112 \mathrm{lbs}$. bags $\$ 12.00$.

Wizard Brand Powdered Sheep Manure. For vegetable and flower gardens, lawns, shrubs, etc., Safe and easy to apply. 5 lbs., 40 c., 10 lbs. 65 c., 25 lbs. $\$ 1.00,50$ lbs. $\$ 1.75 .100$ lbs. $\$ 3.00$.

Grain and Fruit Fertilizer. $1 \%$ ammonia, $8 \%$ phosphate $4 \%$ potash. Prices vartable.

Bowker's Special Potash Fertilizer. $4 \%$ Nitrogen, $8 \%$ Ac. Phos., $7 \%$ Potash. Prices variable.

Agricultural Lime, Fine Ground. Beneficial to all vegetable growth. Corrects the acidity of the soil. Excellent for lawns. 5 lbs, 15c., 10 lbs, 25c., 20 lbs, 50c., 50 lbs. $\$ 1.00$.
Wood Ashes. High in potash. Lightens the soil and is a good fertilizer. 100 lbs. $\$ 3.00$.

Shredded Cattle Manure. $100 \mathrm{lb}$. bags only. A rather coarse animal manure. Excellent for improving and lightening the soil and for mulching. Bag $\$ 3.00$.

Blood Meal, or Flour. 85 per cent. protein, or 13 per cent. nitrogen. A rich and concentrated fertilizer and forcer. $5 \mathrm{lbs}$. 50 c., 25 lbs. $\$ 2.00,100$ lbs. $\$ 6.00$.

Bone Meal. Fine ground. Excellent for mixing with the soil for potting. Fine for Roses. Assists in sweetening the soil. Pkgs. 15 and 25c., 5 lbs. 40 c., 10 lbs. 65 c., 25 lbs. $\$ 1.00,50 \mathrm{lbs}$. $\$ 1.75 .100$ lbs. $\$ 3.00$

Bone Flour. $100 \mathrm{lbs} . \$ 7.00$

Moss, Sphagnum. For filling Orchid baskets and for mixing with potting soil to hold moisture. In bales 35 to $40 \mathrm{lbs}$. lb. $15 \mathrm{c}$.

Peat, Orchid. For potting Orchids, etc. Lb., 25c.

Nitrate of Soda. Price very variable, ask for quotations.

Sulphate of Ammonia. Price very variable, ask for quotations.

Muriate Potash. Prices variable, ask for quotations.

Soot, Scotch. In $125 \mathrm{lb}$. bags only. $\$ 6.00$ per $100 \mathrm{lbs}$.

\section{StIM-U-PLANT \\ PLANT STIMULANT TABLET}

Trade Mark Registered U. S. Patent Office

Plant food in tabet form. Most modern and scientific method of fertilizing all kinds of growing plants in home garden orchard and on farms. A tablet with a guaranteed chemica analysis of 11 per cent Nitrogen, 12 per cent. Phosphoric Acid and 15 pim as high water soluble materials of great feeding power.
Tablets should be used directly in the soil at the base of the plants or dissolved in water and applied to the soil. Do not spray on the foliage. Packed in four sizes.

Trial Size containing 10.tablets............... \$0.15 Small Size containing 30 tablets ................ 25 Medium Sire containing 100 tablets..............................

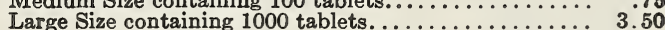

Superior House Plant Food. An ordorless plant food immediately soluble in water and available to plant growth as soon as applied. In cans, 25c., 50c. and $\$ 1.00$

"'Better Bloom." A harmless plant food especially adapted for flowering plants and ferns. Pkg., 25c.

"Shur Gro." Plant Food and Fertilizer. Odor- less. Pkg., 10c; 10-lb. bag, 50c. For lawns, flowers, and vegetable gardens.

New Plant Life. A liquid plant food and tonic. Promotes foliage and blooms. An ideal preparation for Ferns and all other house plants. Price 25c per can.

White Rose Plant Food. A combination of Ammonia, Phosphoric ac. and Potash in Proper proportions to give the very Best Results. Per can 25c. 5 -lb. can, 75c, 10 lbs., $\$ 1.25,100$-lb. bag, $\$ 6.50$.

\section{POULTRY FEEDS and SUPPLIES}

We have a very complete line of Poultry Remedies and Supplies too numerous to list; also Prepared Poultry Feeds. All kinds of grains. As prices on Feed are variable we would be glad to quote on application. 


\section{Garden Implements and Requisites}

Asparagus Knives.

B oxes, Aluminum Savo. A. $-8 \times 9 \frac{1}{2} \times 23$, $\$ 3.00 ;$ B. $-8 \times 91 / 2 \times 29$ inches, $\$ 4.00 ;$ C. $-8 \times 91 / 2 \times 35-$ inches, $\$ 4.50 ;$ D. $-8 \times 91 / 2 \times 41, \$ 5.00 ;$ E. $-8 \times 12 \times 12$ inches, $\$ 3.50$; F. $-12 \times 12 \times 12$ inches, $\$ 4.00$.

Brackets, Hanging.

Bleachers, Celery. Doz., 45c; 100, $\$ 3.00$.

Boxes, Green Wooden Regular 18 in. $75 \mathrm{c}, 24$ in. 80 ;c 30 in. $\$ 1.00 ; 36$ in. $\$ 1.15 ; 42$ in. $\$ 1.25 ; 48$ in. $\$ 1.50$.

Heavy. 24 in. $\$ 1.15 ; 20$ in. $\$ 1.35 ; 36$ in. $\$ 1.50$; 42 in. $\$ 1.75$.

Boxes, Window, Success. 24 in. "A" $\$ 1.35$ each; 30 in. $\$ 1.75$ each; 36 in. $\$ 2.75$ each; 42 in. $\$ 3.50$ each; 30 in. "D" $\$ 3.50$ each; 36 in. $\$ 4.50$ each.

Brackets. Success. $\$ 1.00$ pr.

Bellows, Powder. Small, 10c; Medium, 15c.; Jumbo, 30c.

Cans, Greenhouse Watering. Round. 4 qt., $\$ 2.75 ; 6$ qt.. $\$ 4.00 ; 8$ qt., $\$ 4.50 ; 10$ qt., $\$ 4.75$; 12 qt., \$5.25.

Cans, Greenhouse Watering. Oval. 6 qt., $\$ 4.75 ; 8$ qt., $\$ 5.00 ; 10$ qt., $\$ 5.50$.

Dibbles. Wood handle, iron point.

Forks. Digging or Spading, Manure; D. Handle, Hay, 2 and 3 tines, long handle, Ladies Weeding, short handle.

Garden Labels. 8 in., 15c. doz, 100, 85c.; 10 in., 20c. doz.; 100, $\$ 1.00 ; 12$ in., 25c. doz., 100, $\$ 1.30$. $40 \mathrm{c}$.

Grafting Wax. 1/4-lb., 15c.; 1/2 lb., 25c.; 1 lb.,

Garden Tools for Ladies. Set 3 pieces.

Grass Hooks, or Sickles.

Hoes, Garden, Draw, Scuffle and Drill.

Hose, Garden and Greenhouse.

Hose Couplings and Nozzles and Menders.

Hose Reels.

Labels-Pot. 41/2 inch, Painted, 30c. per 100; $\$ 2.30$ per $1000 ; 5$ in., plain, 30c. per $100, \$ 2.30$ per 1000 ; 5 in., painted, 35 c. per $100, \$ 2.75$ per 1000 ; 6 inch, painted, 40c per $100, \$ 3.00$ per 1000 .

Labels, Tree. Copper Wire. $3 \frac{1}{2}$ in., painted, 40 c per $100, \$ 3.00$ per 1000 .

Labels, Weatherproof No. 2. 50c. per doz., $\$ 4.00$ per 100.

Plant Stakes. Bamboo and Green. $2 \mathrm{ft}$., 15c. per doz., $\$ 1.10$ per $100,21 / 2 \mathrm{ft}$., $18 \mathrm{c}$. per doz., $\$ 1.25$ per $100 ; 3 \mathrm{ft}$., $20 \mathrm{c}$. per doz., $\$ 1.50$ per $100 ; 4 \mathrm{ft}$., $25 \mathrm{c}$. per doz., $\$ 2.00$ per 100 ; 5 ft., 30 c. per doz., $\$ 2.25$ per 100 ; $6 \mathrm{ft}$., plain, 35c. per doz., $\$ 2.50$ per $100 ; 10 \mathrm{ft}$. plain, 10c each; $\$ 1.00$ per doz.

Plant Stakes. Wood. Green. Square. $2 \mathrm{ft}$., 40 c. per doz., $\$ 2.50$ per $100 ; 21 / 2 \mathrm{ft}$., $50 \mathrm{c}$. per doz., $\$ 4.00$ per $100 ; 3 \mathrm{ft}$., $75 \mathrm{c}$. per doz., $\$ 5.50$ per 100 ; $31 / 2 \mathrm{ft}$., 90c. per doz., $\$ 7.00$ per $100 ; 4 \mathrm{ft}$., $\$ 1.25$ per doz., $\$ 9.00$ per $100 ; 5$ ft., $\$ 1.75$ per doz., $\$ 13.00$ per 100 ; 6 ft., $\$ 2.00$ per doz., $\$ 17.00$ per 100 .

Plant Stakes. Wood. Round. Green. $21 / 2 \mathrm{ft}$., 60 c. per doz., $\$ 4.50$ per $100 ; 3$ ft., 80 c. per doz., $\$ 6.00$ per $100 ; 31 / 2 \mathrm{ft}$., $\$ 1.00$ per doz., $\$ 7.25$ per 100 ; $4 \mathrm{ft}$., $\$ 1.25$ per doz., $\$ 9.00$ per $100 ; 5 \mathrm{ft} ., \$ 1.75$ per doz., $\$ 13.00$ per 100 .

Plant Stakes, Pot. 12 in., 8c. per doz., 40c. per $100 ; 18$ in., 10c. per doz., 50c. per 100.

Pruners. Long-handled Tree. $6 \mathrm{ft}$., $\$ 1.50$ each; $12 \mathrm{ft}$., $\$ 1.75$ each.
Pots. Standard, $3 / 4$ and Bulb.

Pots. Standard, $3 / 4$ and Bulb.

\begin{tabular}{|c|c|c|c|c|c|c|c|}
\hline & Each & Doz. & 100 & & Each & & \\
\hline & in.. & $\$ 0.18$ & $\$ 1.20$ & 7 in. & & & \\
\hline $21 / 2$ & in.. & .20 & 1.50 & 8 in.. &.$\quad .25$ & 2.50 & \\
\hline 3 & in.... & .30 & 2.00 & 9 in.. & .35 & 4.00 & \\
\hline & in....\$0.05 & .40 & 3.00 & 10 in.. . & .50 & & \\
\hline & in.... .06 & .65 & 5.40 & 11 in & .75 & 8.00 & \\
\hline 6 & in.... .12 & 1.20 & 8.20 & 12 in... & 1.00 & 10.00 & \\
\hline rchi & id pots. & Each & Doz. & & & Each & \\
\hline & & & & 8 in & & & \\
\hline & & & 3. & & & & \\
\hline & & .40 & 4.5 & 10 in. . & & 1.00 & \\
\hline & & & & & & & \\
\hline & & 0 & .2 & $8 \mathrm{i}$ & & & \\
\hline & & & .4 & $10 \mathrm{i}$ & & & \\
\hline & & & & 11 in. & & .18 & \\
\hline & & 08 & 80 & 12 in. & & .25 & \\
\hline
\end{tabular}

HANGING BASKETS. No. $150 . \quad$ Each Doz. 9 in.......................... $\$ 0.50 \quad \$ 5.00$

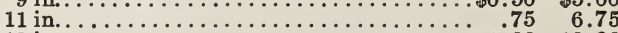
13 in.......................... $1.00 \quad 10.00$

No. $25.83 \frac{1}{4}$ in.................... .60 6.00

No. 333

7 333.

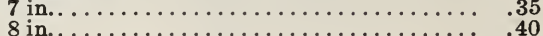

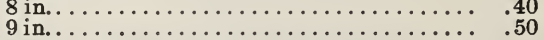

Wire Baskets. Small 40c; Med. 50c; large 60c.

Fern Dish Linings. 4 in., $8 \mathrm{c}$ each; 5 in., $10 \mathrm{c}$. each; 6 in., 12c. each; 7 in., 15c. each; 8 in., 25 c. each.

Paper Pots, Neponset. $21 / 4$ in., 10c. per doz., $21 / 2$ in., 12c. per doz., 60c. per $100 ; 3$ in., 15c. doz. $75 \mathrm{c}$. per $100 ; 31 / 2$ in., $20 \mathrm{c}$. per doz., $\$ 1.00$ per 100 ; 4 in., 25c. per doz., $\$ 1.20$ per 100 ; 5 in., 35c. per doz., $\$ 2.00$ per 100 . 6 in., 45 c. per doz., $\$ 2.50$ per 100 .

Raffia. Best quality natural color. Lb. 25c, 5 lbs. $20 \mathrm{c}$

Saws, Pruning. 6 different styles and sizes.

Scythe Stones.

Shears, Pruning, English Hedge, Grass, Border, English Lopping.

Shovels, Garden, Square and Round Point.

Spades, Garden. Square Point, Extra Heavy Garden.

Sprinklers, Rubber, Plant. $\$ 1.30$ each.

Sprinklers. Lawn. Various sizes and styles.

Sprayers. Hand, Garden. Compressed Air Tank, Knapsack. 1 and 2 qt. tin, brass and galvanized.

Sprayers. Bucket, also large size Garden Tank and wheelbarrow sprayers.

Twine. Sea Island, Ball, Silkateen, Spool.

Thermometers. Common Tin and Wood Backs, Dairy, Brooder, Incubator, Self-Registering.

Trowels. Garden, Transplanting.

Trellis. Wood. Green. 25c., 50c., 75c., \$1.00, $\$ 1.50$ each.

Trellis. Pot, Wire, 7 sizes.

TUBS, Cedar. Green painted.

No. 1,6 in. diameter.$\$ 0.75$ No. 8,13 in. diameter $\$ 2.00$

No, 2,7 in diameter. meter 2.40 (in diameter 1.00 No 11,16 in diameter 3.00 No. 5, 10 in. diameter. 1.20 No. 12, 17 in. diameter 3.30

No. 6,11 in. diameter. 1.50 No. 13, 18 in. diameter 4.00 No. 7, 12 in. diameter. 1.70 No. 14,19 in. diameter 4.70

Wheelbarrow. Wooden, Garden.

Weeders. Excelsior, Magic, Cultivator, Adjustable, etc.

Water Ballast Rollers. 


\section{Insecticides and Remedies for Plant Diseases}

\section{All prices subject to market changes.}

ANT Destroyer. For use in the garden and on leaves. Breaks up and destroys ant nests. $1 / 4 \mathrm{lb}$. $25 \mathrm{c}, 1 / 2 \mathrm{lb}$. $40 \mathrm{c}$.

Aphine. An insecticide that kills plant lice of many species. Destroys Green, Black and White Flies, Thrips, and prevents white and brown scale. Dilute with 15 to 40 parts of water. $1 / 4$ pt. $25 \mathrm{c}$., $1 / 2$ pt. $45 \mathrm{c}$., 1 pt. $75 \mathrm{c}$., 1 qt. $\$ 1.25$, 1 gallon, $\$ 3.00$.

Arsenate of Lead Powder. One to $1 \frac{1}{2} \mathrm{lbs}$. to 50 gallons of water. Effective against all chewing insects. Sticks well to the foliage. It is white and shows where it has been applied. $1 / 2 \mathrm{lb} ., 25 \mathrm{c} ., 1 \mathrm{lb}$., 45c., 5 lbs., $\$ 2.00$., 10 lbs., $\$ 3.75$.

Black Flag Powder. Kills Ants, Bed Bugs, Roaches and certain Moths and insects in house and on plants. $25 \mathrm{c}, 40 \mathrm{c}, 75 \mathrm{c}$.

Black Leaf 40. For spraying vegetables, fruits and flowers, to destroy lice and sucking insects. 1 oz. bottle, 35c., 1/2 lb., $\$ 1.25$., 2 lbs., $\$ 3.75$, 10 lb. tin, $\$ 13.50$.

Bordeaux Zinc, Dry. For fungus diseases and chewing insects. A combined spray. $1 \mathrm{lb}$., $50 \mathrm{c}$.

Bordeaux Mixture, Dry. For all fungus diseases $1 \mathrm{lb} .40 \mathrm{c} ; 5 \mathrm{lbs}$. $\$ 1.60$.

Copper Solution. Prevents black and brown rot, mildew and other grape diseases, pear and apple scab, leaf blight, tomato rot, etc. Dilute 1-100 parts of water, spray lightly. Qt., \$1.25.

Cut Worm Killer. 1 lb., pkg., 35c.

Dalmatian Powder. For Roaches, Ants and Lice. $1 / 4$ lb. $50 \mathrm{c}, 1 \mathrm{lb}$. $\$ 1.50$.

Fish Oil Soap. For washing trees and destroying insects on bark, also for lice. $1 / 2 \mathrm{lb}$. pkg., 20c., $1 \mathrm{lb}$. pkg., 30c., 5 lbs., $\$ 1.00$

Fungine. For mildew, rust and other blights; does not stain foliage. $1 / 2$ pt. $40 \mathrm{c}$, 1 pt. $65 \mathrm{c}$., qt., $\$ 1.25$.

Grape Dust, Hammonds. For prevention of mildew on Roses, Grapes, Gooseberries. Apply with bellows. 5 lbs., $90 \mathrm{c}$.

Hellebore. Apply dry or mix with water, 3 ozs. in 1 gallon. $1 / 4 \mathrm{lb} .20 \mathrm{c} ., 1 / 2 \mathrm{lb} .35 \mathrm{c} ., 1 \mathrm{lb} .65 \mathrm{c}$.

Kerosene Emulsion. For cabbage worms, scale on trees, melon lice, rose bugs, etc. Dilute with 25 to 50 parts water, 1 qt. can, $75 \mathrm{c}$.

Lemon Oil. For destroying scale, caterpillar, mealy bug, ants, etc. $1 / 2$ pt., $35 \mathrm{c} ., 1$ pt., $60 \mathrm{c} .$, qt., $\$ 1.00$.

Lime Sulphur Solution. For San José scale. 1 gallon makes 15 gallons with water. 1 qt- $60 \mathrm{c} ., 1$ gal. $\$ 1.25$.

Lime Sulphur, Dry. Soluble in water. Light and convenient for spraying fruit trees and shrubs when dormant against San José oyster shell scale, peach leaf, curl and brown rot. $1 \mathrm{lb}$. makes 4 gals. spray. Lb. 30c., 5 lbs., $\$ 1.25 ; 10$ lbs., $\$ 1.90$.
Melrosine. A concentrated liquid insecticide, a positive remedy for Rose Bugs, Plant lice, Black, Green and Saw Flies, Red spiders, Aster Bugs, Mealy Bugs etc., Price $50 \mathrm{c}$. and $\$ 1.00$ per can.

Nicofume Liquid. For spraying for aphis, thrips, plant lice, flies on Chrysanthemums, etc., also for fumigating greenhouses. $1 / 4-\mathrm{lb}$. can $75 \mathrm{c}$., $1-1 b . \$ 2.25$.

Nicofume Tobacco Paper. For fumigating. 24 sheets $\$ 1.25,144$ sheets $\$ 5.00,288$ sheets $\$ 11.00$.

Nicoticide. A tobacco spray used against Green Fly and Thrip on Plants. $1 / 4$ pt. can $75 \mathrm{c}, 1$ qt. can $\$ 4.25$.

O. K. Plant Spray, Wilson's. A powerful and efficient spray against Lice, Scale, White Fly, etc. Gal., $\$ 3.00$.

Para Dichlorobenzene. A remedy for Peach Tree Borers. Use $1 \mathrm{oz}$. to each tree. $1 \mathrm{lb} .40 \mathrm{c}$.

Paris Green. Use at the rate of $1 \mathrm{lb}$. to $200 \mathrm{gal}-$ lons water as a spray. For all chewing insects. Lb. 65c., 2 lbs. $\$ 1.15 .5$ lbs. $\$ 2.75$.

Path and Gutter Cleaner, Hammond's. For killing weeds, ivy, grass, etc., in paths, gutters, tennis courts, etc. 1 gal. makes 40 gals. Qt. 75c.

Pomodust. A dusting powder to prevent blight and black spot on roses; also kills chewing insects. $1 \mathrm{lb}$. cans $25 \mathrm{c}$ each, $5 \mathrm{lb}$. cans, $85 \mathrm{c}$.

Pyrox. Best and safest and most effective allround spray for all chewing insects, blights and fungus. A splendid potato spray. Lb. $40 \mathrm{c}$., $5 \mathrm{lbs}$. $\$ 1.50,10 \mathrm{lbs}$. $\$ 2.50,25 \mathrm{lbs}$. $\$ 5.75$.

Scalecide. For San José scale. A miscible petroleum oil. Mixes readily with water. 1 gal. to 15 to 20 gals. water. Qt. can 60c., gal. $\$ 1.45$.

Slug Shot, Hammond's. One of the finest dusting powders for all insects on Cabbage, Turnips, Beets, potato bugs, currant worms, etc. Helps to prevent blight on Melons, Cucumbers, Roses, etc. Lb. 20c., 5 lbs. 60c.

Soap, Sulpho-Tobacco. For plants and animals. Remedy for Black and Green Alphis, Mealy Bug, Red Spider on Plants and Lice and Fleas on domestic animals. Price $3 \mathrm{oz}$. cake $15 \mathrm{c}, 8 \mathrm{oz}$. cake $25 \mathrm{c}$.

Sulphur Powder. Valuable protection against mildew on Grapes, Roses, etc. Lb. 20c., 10 lbs. 15c. per $\mathrm{lb}$.

Thrip Juice. 1 pt. 75 c., 1 qt. $\$ 1.10$.

Tobacco Dust. Lb. 15c., 10 lbs. $\$ 1.00,100$ lbs. $\$ 8.00$.

Tree Tanglefoot. One application remains sticky for three months. Protects trees from all climbing insect pests. Lb. tin 50c., 5-lbs. $\$ 2.40$.

Vermine. A germicide for all soil vermin, such as cut, eel, wire and grub worms, ants, slugs, maggots, etc. $1 / 2 \mathrm{pt}$. cans $45 \mathrm{c} ; 1 \mathrm{Pt}$. cans $75 \mathrm{c} ; 1 \mathrm{Qt}$. cans $\$ 1.25$. 


\section{For Everything that Grows}

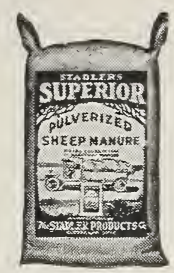

A concentrated natural fertilizer that promotes strong healthy growth of all plants and makes a rich fertile soil. Absolutely weedless and far superior to chemical fertilizers and stable manure.

For Lawns, Gardens and Shrubbery it is unequalled-produces thick velvety green turf, healthy foliage and vivid colored flowers. Use $10 \mathrm{lbs}$. for each 100 square feet raked into surface soil.

Vegetable Crops-Promotes quick early growth of crisp tender vegetables. A profitable fertilizer for the practical grower. Use in drill or broadcast $10 \mathrm{lbs}$. for each 100 square feet.

Florists need this manure. It is safe and dependable for feeding, mulching or as a liquid manure. Its strong forcing action insures a profitable crop.

Potted Plants-One tablespoonful for each 6-inch pot once every two weeks will give your plants new life.

Liquid Manure-Fine for house plants and window boxes. Mix one pound of manure to five gallons of water. Apply direct to soil once a week until plants show healthy growth.

\section{Don't Plant Without Superior Brand}

ONE BAG EQUALS A WHOLE WAGON LOAD OF STABLE MANURE

Prices: $5 \mathrm{lb}$. bag 40c; $10 \mathrm{lb}$. bag $65 \mathrm{c} ; 25 \mathrm{lb}$. bag $\$ 1.00 ; 50 \mathrm{lb} . \$ 1.75 ; 100 \mathrm{lb}$. bag $\$ 3.00$.

WE SELL THE FAMOUS

PLANET Jr.

CULTIVATORS - SEEDERS - WEEDERS

AND OTHER

GARDEN TOOLS

Call and examine the samples we have on exhibition

CATALOGUE FREE 


\section{Our New Department}

\section{Domestic and Imported BIRDS}

HARTZ MOUNTAIN and ST. ANDREASBURG CANARIES Guaranteed Singers

Paroquets

Gold Finches

Java Rice Birds

Japanese Robins

Panama and Brazilian Parrots

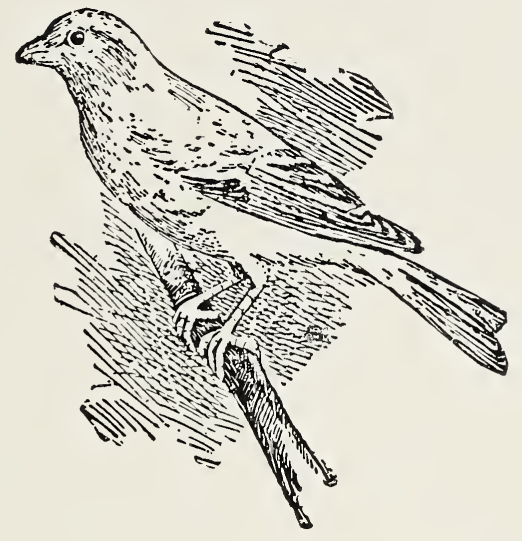

BIRD CAGES

in large assortment of

Styles and Sizes

Brass and Ivory Finishes

BIRD SEEDS

and

SUPPLIES

BIRD REMEDIES

SEED CUPS

\section{GOLD FISH}

FANCY JAPANESE FAN TAILS, COMETS, TELESCOPES.

AMERICAN GOLD AND PEARL FISH

AQUARIUMS

in many styles and sizes

Globe, Squat, Square and

Ornamental

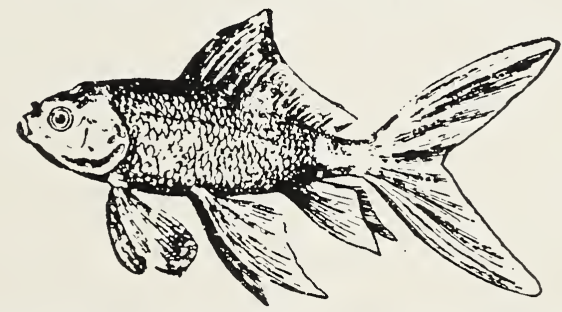

Natural Fish Food Caboma Fish Plant Aquarium Pebbles

Fancy Shells

Aquarium Ornaments

(Special Wholesale Prices to Dealers on Gold Fish)

BENNETT'S MILK BONE-OLD TRUSTY

SPRATT'S OVALS, SQUARE, FIBO. AUSTIN'S DOG BISCUIT

CLAYTON'S DOG REMEDIES SPRATT'S DOG REMEDIES

SERGEANT'S DOG REMEDIES

DR. DANIEL'S DOG REMEDIES

FREE EXPERT ADVICE ON BIRDS AND PET STOCK

\section{QUEEN GITY SEED AND NURSERY CO. Inc.}

Seed Store: 616-618 WASHINGTON STREET opp. Washington Market, BUFFALO, N. Y.

Greenhouse and Nursery Stock: South Eggertsville Road, Eggertsville, N. Y. 

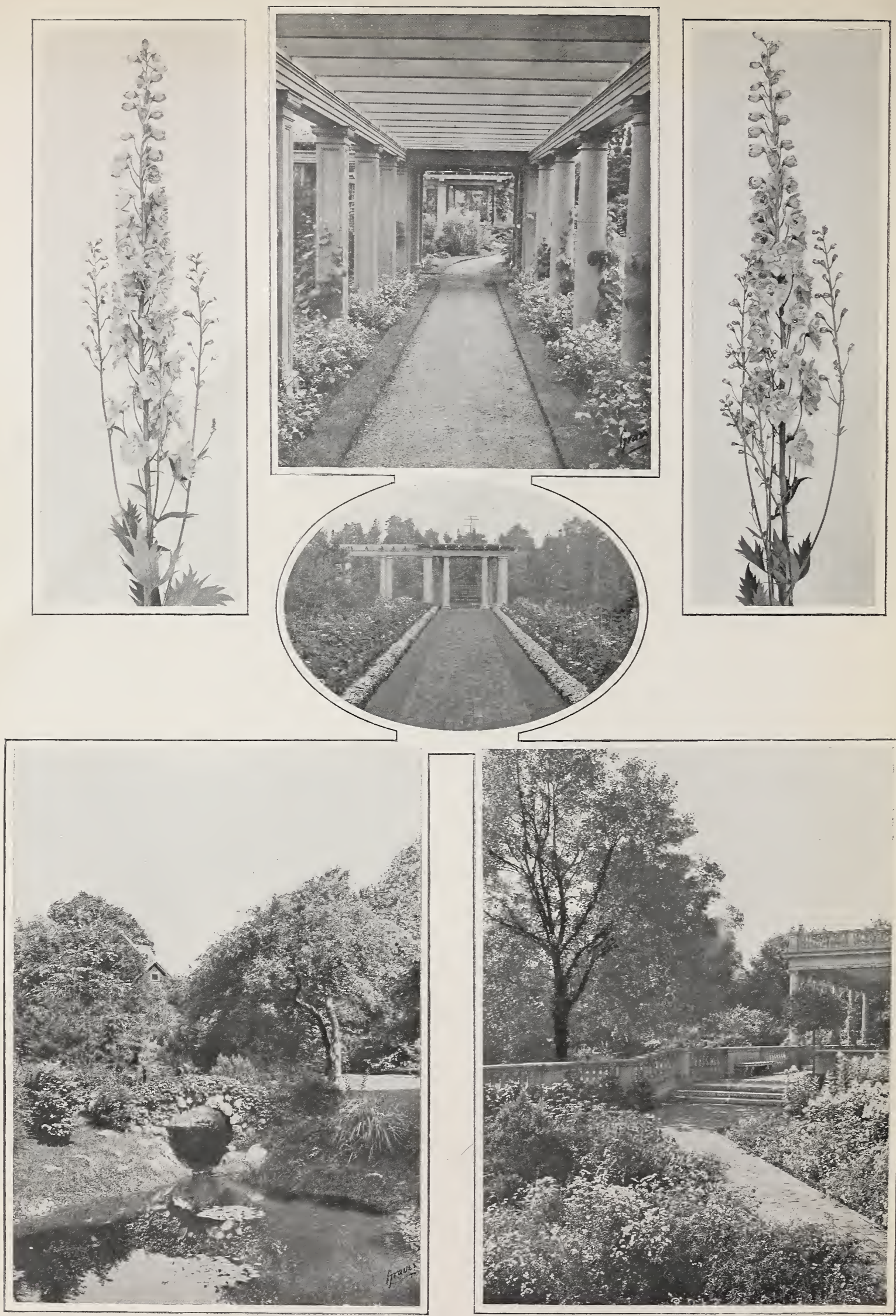